in

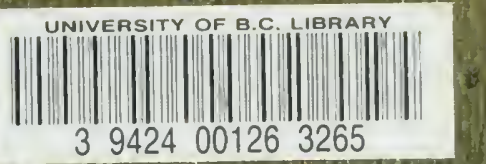

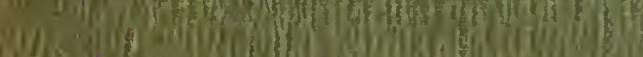

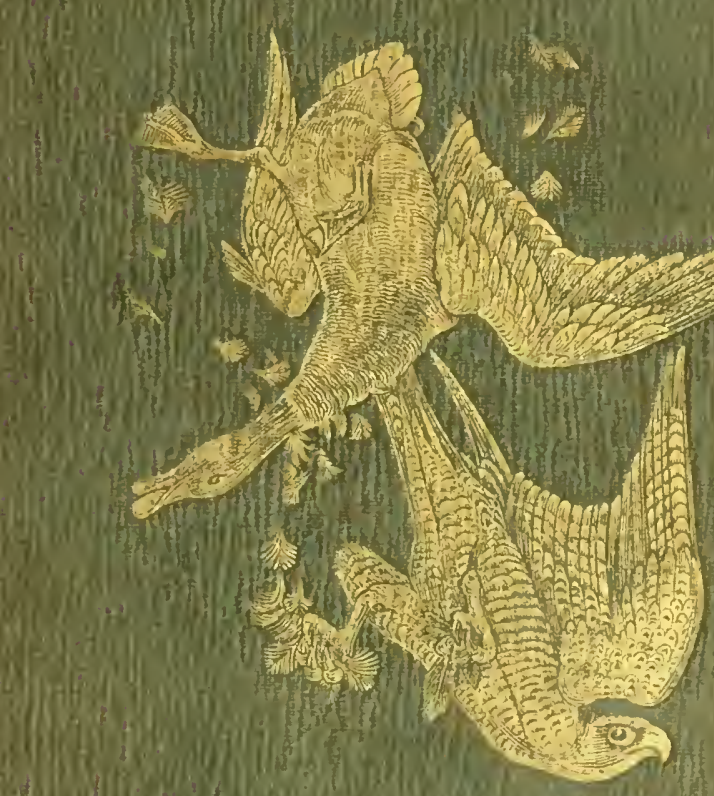

13) 1 (6)

(16)

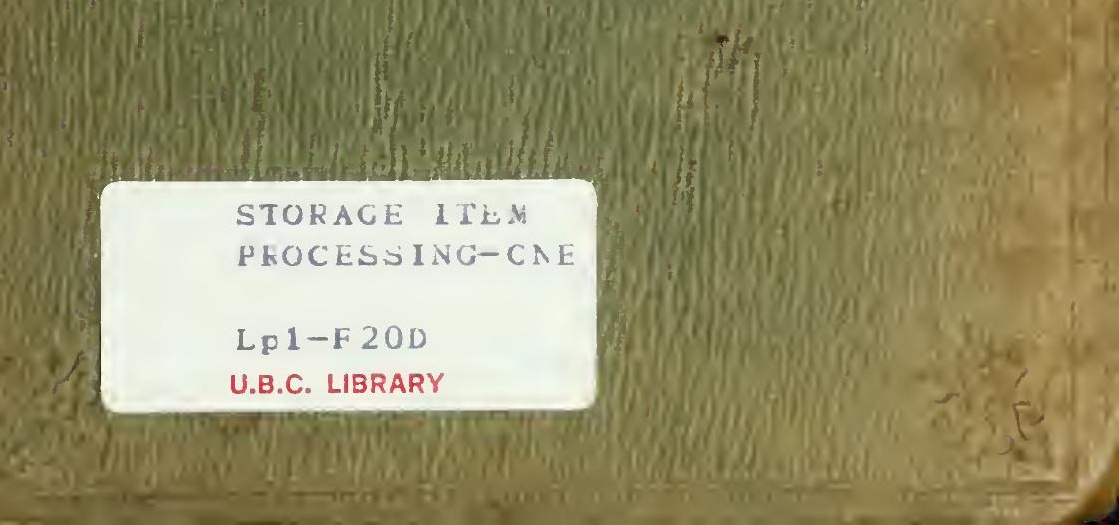




\section{THE LIBRARY}

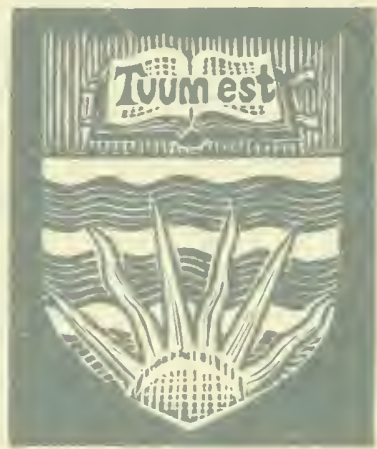

THE UNIVERSITY OF BRITISH COLUMBIA 
Digitized by the Internet Archive in 2010 with funding from

University of British Columbia Library 
079 


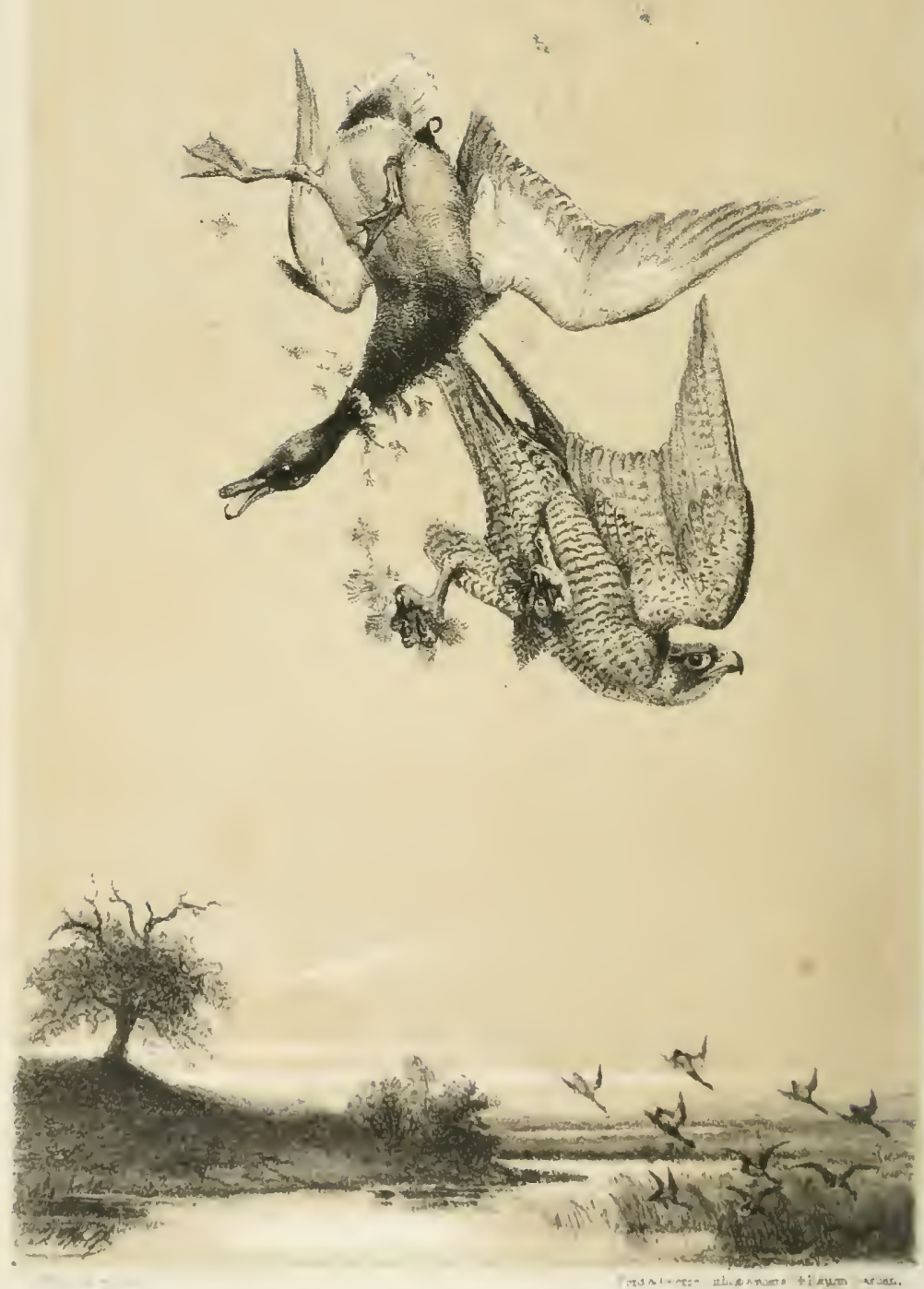




\title{
G.ANE BIRDS AND WILD FOWL:
}

\author{
THEIR FRIENDS AND TIIEIR FOES.
}

A. E. KNOX, M.A. F.L.S.

AUTHOR OF' ORNITEOLOGICAL RAMBLES IN SUSSEY.

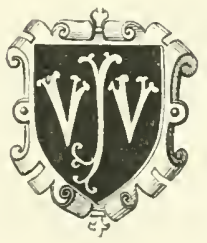

LONDON :

JOHN VAN VOORST, PATERAOSTER ROW.

I. UCCC.L. 
LONDON

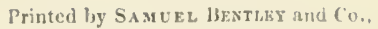
Bangor House, Stoon Larim. 


\section{PREFACE.}

ThE following papers are chiefly derived from the observations and experiences of the Author, in reference to those birds which are usually the objects of pursuit with the British sportsman; and to certain other animals which, either justly or erroneously, are supposed to be injurious to their welfare and increase.

The ornithologist, therefore, who opens this little book in the expectation of finding a scientific treatise on those families of the rasorial, grallatorial, and natatorial orders which might be supposed to be included in its rather comprehensive title, will be doomed to disappointment; while those indulgent readers who could find amusement, or relaxation from graver pursuits, in the author's 'Ornithological Rambles' may perhaps give a favourable reception to these pages, in which he has endeavoured to blend entertainment with instruction, and thus add new votaries to a loving observation of Nature. 



\section{CONTENTS.}

\section{CHAPTER I.}

The Partridge-Game of the Farm-Certain Agricultural Improvements injurious to the Partridge and adverse to the Sportsman - Common Partridge scarcely ever known to breed in Captivity-Easily domesticatedAnecdote-A Friend to the Farmer-Has many Enemies, Quadruped and Biped-Destructive mode of NettingThe Quail-Its Capture in France, Sieily, Malta, \&c.Identical with the Bird of Scripturc-Red-legged Partridge and Common Partridge-Affinity and consequent Hostility-Examples among Birds and Quadrupeds. . 1

\section{CHAPTER II.}

Peregrine Faleon-Truthfulness of Virgil's Description - Haunts of the Peregrine-Hereditary DominionsExtensive Geographical Distribution-Grouse and Peregrine-Ineident in Ireland-Paradise for Wild FowlThe Falcon's Watch-tower-Disappointment-Change of Tactics-Attack and Pursuit-Unsuccessful SwoopChace continued-Death of the Mallard-The Rod and the Gun-Falcon and Tcal. 


\section{CHAPTER III.}

The Woodeock-Summer and Winter Haunts-Decrease in England-Erroneous Reason assigned - The true Cause suggested-Slaughter on the Shores of the Mediterranean and the Adriatic - Clumber SpanielsColonel Parker's Notes - Shooting Expeditions to the Morea and Thessaly-Kornupeli-Aspect of the Country - Covers of Arbutus and Oleander-Gulf of SalonicaReflections on the preeeding Aceount-Protection recommended-Distribution in the British Islands-A Woodcock Battue in Ireland-The Common Snipe-The Solitary Snipe. . . . . . . . .

\section{CHAPTER IV.}

Severe Season of 1838, 1839-Winter Seene on the Coast-Preparations for an Expedition to Pagham Harbour-Equipment-Irish Water Spaniel-Frozen FishArrival at the Harbour - Flocks of Waterfowl - Wild Swans-Observation and Plan of Operations-Mysterious Object-Formidable Rival-A mbuseade-V Various species of Wild fowl-Suspense-The Grent Gun-Off at lastCripple Chaec-Retriever and wounded Swan-The Hero of the Gun-boat-Return. . . . . . 56

\section{CHAPTER V.}

The Ploeasant-Care and Attention neeessary for his lnerease and Welfare-Tame Plieasants-Outlying Nests -Eggs-Foster Mothers-Barn-door and Bantam Hens - Food of the Chicks-Ants' Eggs-l lest Mode of Colleeting them-Out-of-door Management of the loung Pheasants-'The Gapes'-Prevention better than CureSingular Instance of its Malignity - Origin of the Disease, anil consequent lneffieacy of ordinary Reeipes-Colonel 
Montagu's Cure - Pheasants' Eggs - The P'raetice of Purehasing them reprehended-Importance of obtaining them in a Fresh State - Experiment to effeet that Objeet - Aeeident - Open Pheasantry - The RivalsThe Vietor ranquished-Nature the best Guide-Unexpected Result. . . . . . . .

\section{CHAPTER VI.}

Various Speeies of Wild Geese-Grey-lag and Whitefronted - Distinguishing Charaeters-Origin of the Domestie Stoek-Bean Goose-Pink-footed Goose-Berniele-Brent Goose - Shieldrake - Foreign Dueks and Geese nnadvisedly admitted into the British Fauna-Probable Cause of the Error-Ducks on the British Coasts -Diversity of Haunts, Habits, Food and StruetureDeeoys - Wild Fowl Shooting - Young Water Fowl devoured by Pike-The 'Bird-fly'-Observation. .

\section{CHAPTER VII.}

Red Grouse-Limits of its Range-1Natural Enemies, winged and four-fuoted-The Badger unjustly proseribed -Unsueeessful Attempts to re-establish the Red Grouse in the South of England-Ptarmigan-Its Haunts and Habits - British Game Birds - Order in which they arrive at Matnrity-Annual Importation of PtarmiganHighland Moors-Mayo Mountains-Shooting Expedition-Lodge-Baekward Season-Operations deferredWild Seenery-Youthful Ardour and Veteran Coolness -Variety of Sport. . . . . . . . 114

\section{CHAPTER VIII.}

The Woodeoek-Modes of Capture-Net and GinWoodeoek trapped-Attempts to Rear it in Confinement 
-Insatiable Appetite of the 'Bird of Suetion'-Rapid Digestion - Crepuscular Habits - High-road GunnersNetting_Snares, Ancient and Modern-The Old Poacher and lis Springe.

\section{CHAPTER IX.}

Faleonry - Youthful Attempts in the 'Noble Art'Heron Hawking-The Look-out-The Chaee-An Irish $\mathrm{Bog}$ - Fabulous Errors - Magpie Hawking - Colonel Bonham's Hawking Expericnces-Seardroy-Peregrine Faleons-Grouse Hawking-Russian Setters-The Goshawk eompared with the Peregrine - Their respective Merits - How does the Falcon strike her Quarry? Woodeock Hawking-Convincing Fact-Aneedote-The Faleon's last Flight — 'Faleon' and 'Tiereel' - Wild Duek, Blackeoek, and Ptarmigan Hawking - 'Playing' the Hawks-The Faleon at Sea-Rceognition and Reeovery. . . . . . . .

\section{CHAPTER X.}

Farourite Haunts of the Pheasant in a state of Niture -A more general Distribution of the Speeies desirableIneffieieney of the Game laws-Importanee of a quict and secure Place of Retreat-Asylum for Phensants at Walton Hall-Descriptive Sketeh-Crowing of Cock Pheasants-Seenery-Valley of the Rother-Singular Oecurrence-Importanee of Evergreen Timber Trees in Preserves.

\section{CHAPTER XI.}

Injuries inflieted on various Birds during the Breeding Season-Robbery of Eggs-Plover's Eggs-Eggs of Terns and Gulls-Blacklieaded Gulls-Preserves of those Birds 
-Gullery at Scoulton- The Gannet or Solan GooseIVild Geese and Ducks-The Eider Duck-Its Distribution and Domestic Economy- Plunder of the Eqgs and Dewn-Traffic in the Eggs of Rare Birds-Injurious Consequences - Scientific and Amateur Collectors-Eagles' Eggs - French and Dutch Purveyors - Tricks of the Trade-Depredations committed on Game Birds during Incubation - The Red Grouse - Feathered Bandits Grouse and 'Scaul Crows'-Poachers-The Egg Stealer the most Mischievous and Difficult to Detect-Inảrect Encouragement thoughtlessly Afforded-Pheasants' Nests - Habits of the Hen Pheasant - Tactics of the Egro Stealer - Ignorance of Game-keepers - Persecution of comparativcly Harmless Animals-Duties of a Keeper during the Breeding Season. . . . . . . 191

\section{CHAPTER XII.}

The Capercaillic-Characteristic Habits-Nature of the Country suited to it - Unsuccessful Attempts to Naturalize it in England-Restoration of the Capereaillie to Scotland-Mode of Management and PropagationPresent Condition of Capereaillic at Taymouth - The Black Grouse-Its introduction into Ireland desirableNatural facilities for its establishment there-Obstacles to its Increase in England-Plan recommended-Diffculties to be surmounted-Unity of Interest and Mutual Adrantage. . . . . . . . . . 218

\section{CHAPTER XIII.}

The 'Random Shot'-Ficld Sports-Cruelty tempererl by Mcrey-Museum Lectures-Maxims for Young Sportsmen-Destructirencss of a Bad Shot-A Case in Illustration-Retriever over-matehed-Evil Consequences of carcless Shooting and Random Shote-The best not infal- 
lible-Necessity and Use of a good Retriever-The most promising Breed-Experiments and Observations-Imfortanee of Discipline-A Field Day. . . . . . 233

\section{CHAPTER XIY.}

Four-footed Vermin-Less Destructive than the Human Poacher-The Fox-Conflicting Interests of the Foxhunter and Game-preserver-Wild Cat-Its Predatory Habits and Ferocity - House Cats running Wild - A Retriever Cat-The Marten - The Polecat, Stoat, and Weascl-Utility of the Weasel-Anecdote-The Hedgehog-Derours Eggs-The Mole-Not only Harmless but Beneficial - Witnesses to his Good Charaeter - Tlie Squirrel unjustly Aceused-Trial without Jury. . 249

\section{ILLCSTRATIONS.}

Deatil of the Mallart Frontispuere.

'OfF at LASt' (i) The Old Poacher's Springe . . . . . 150 Grotse and 'Scatl Crows'. . . . DOG; 


\section{GAIIE BIRDS AND WILD FOWL.}

\section{CHAPTER I.}

"All nature's difference keeps all nature's peace." - POPE.

The Partridge-Game of the Farm-Certain Agricultural Improvements injurious to the Partridge and adverse to the Sportsman-Common Partridge scarcely cver known to breed in Captivity - Easily domesticated-AnecdoteA Friend to the Farmer-Has many Enemies, Quadruped and Biped-Destructive mode of Netting-The QuailIts Capture in France, Sicily, Malta, \&c. - Identical with the Bird of Scripture-Red-legged Partridge and Common Partridge-Affinity and consequent HostilityExamples among Birds and Quadrupeds.

Among our native game birds there is not one more essentially fera naturâ than the common partridge (perdix cinerea), and yet there is none whose increase and welfare have been so directly favoured by the improvements in modern agriculture. The inaccessible peaks of the highest mountains are the resort of the ptarmigan; the 
blackeock loves the unreclaimed swamp and the birchen or alder glen; and the red grouse haunts the moor and the barren heath, retreating invariably before the progress of cultivation. Even the quail would seem to prefer the comparatively slovenly mode of tillage pursued throughout the greater part of Ireland, to the refined system of husbandry now carried on in England.* It is indeed a remarkable fact, that for the last fifty years these birds have been gradually diminishing in the latter country; and, apparently from an opposite cause, have been steadily increasing in the sister island. I have myself found them far more numerous during the winter on the half reclaimed arable grounds, in the immediate ricinity of the great bogs, which had produced a scanty and precarious crop of oats, than in the large, well-fenced, and thoroughly drained wheat-fields. But the partridge is par excellence the game of the farm, and, ceteris paribus, the finer the crops of ecreal grain and the higher the turnips, the larger and more numerous will be the covies found in such districts.

Yet there are certain recent refinements in agriculture that are decidedly injurious to the welfare of this bird, and others which must be earnestly deprecated by the sportsman. The

* Thompson's ' Natural History of Ireland.' 
system of grubbing the wide old fashioned hedges or ' shaws,' and replacing them by narrow, wellclipped quickset fences, wooden palings, or iron rails, ostensibly for the purpose of increasing the surface of ploughing land, deprives the partridge of a favourite nesting place, and the shooter of an excellent and convenient cover into which he could always calculate on driving them when the covies were wild, and the turnips thin. A still more objectionable 'improvement' is the introduction of the 'fagging hook,' which in many counties has superseded the good old fashioned sickle. From the shape and size of this instrument, and the manner in which it is used, the stalks of the wheat are cut close to the ground, and the stubble-the glorious stubbleis thus relentlessly shaved down as effectually as if the operation had been performed by a scythe; and the birds, finding no place of concealment there, or in the neighbouring fences, are quickly alarmed at the approach of the shooter, and, almost before his dogs have begun to range the field, run to the opposite side, scud over the hedge, and take refuge in the nearest piece of turnips. Here, too, 'the modern system' is against the sportsman. The white rounds or Swedes have been sowed in drills for the freer admission of air, and more perfect drainage of 
the soil, so that the field is intersected from one end to the other by straight narrow alleys, along which the birds run with extraordinary speed; and instead of finding them well scattered at or near the spot where they were marked down-as was the case when the old broadcast style of sowing was in vogue-he has the mortification of seeing them far out of shot, topping a gate in a compact body, and may thank his stars if their next flight should happen to be into a patch of clover or standing oats.

But although the common partridge may thus be said to follow in the steps of civilized man, and to be attracted by the labours of the agriculturist, still there is scarcely an instance* of its having ever bred in captivity, while the experiment has frequently proved successful with the red-legged species, as well as with grouse and black game; and yet, individually, the bird is eminently susceptible of domestication in confinement, and has been known to erince the strongest personal attachment to its owner. A lady in West Sussex had a tame partridge for many years: it was a * "There is but one record, as far as I am aware, of the partridge breeling in eonfinement. Sir Thomas Marion Wilson, Bart., had ar small covey of seven or cight hatelied and reared by the parent birds in his aviary at Charlon in the summer of 1842. I saw these birds in 1843."- - Yarrell's 'Hist. of British Birds,' sceonl edition. 
mere chick when it came into her possession, and no dog or parrot ever presented a more perfect model of affection and docility. Although it had the run of the house, its favourite quarters were in the drawing-room, where it would sit for hours on the back of the chair usually occupied by its beloved mistress, and never fail to exhibit every symptom of grief and concern during her occasional absence. When she retired to rest it would accompany her to her chamber, and take up its position near the head of her bed. No wonder then that many a tear was dropped when, from an untimely accident, it 'went the way of all' pets.

The partridge is decidedly a friend to the farmer, even more so than the pheasant; as his consumption of grain is less, and the quantities of injurious weeds and noxious insects devoured by him at all seasons of the year are more consiclerable, in proportion to his size. The Rev. G. Wilkins, who has bestowed much attention to agriculture in Essex, thus addressed a neighbouring farmer who had solicited his advice. "If you have a nest of partridges, encourage them. All the summer they live upon insects, wireworms, \&c., and consider how many millions a corey will destroy in a single summer !" He might have added, and in the winter and spring; 
for, if the crop of a partridge be examined during those seasons, it will be found to contain chiefly grasses, grubs, and minute coleopterous insects, which in the larva state are, in a greater or less degree, injurious to vegetation.

Where the country is open and magpies numerous, the nest of the partridge is subject to frequent depredations, especially during hot dry summers, when the herbage is scanty, and the eggs therefore easily discovered. The peculiar mode of roosting at night generally adopted by the whole covey, who are squatted in a circle in an open part of a stubble field, with their tails in the centre, and their heads turned outwards, although apparently well calculated to enable them to perceive the approach of danger, yet exposes them to certain deadly enemies, among whom the night-prowling fox and the human poacher stand pre-eminent. The former, from his keen scent and stealtly mode of advance, frequently succecds in springing into the midst of the family, and in sacrificing several of their number-especially in wet weather. To say nothing of the various systems of wiring, snaring, trapping, and shooting, usually cmployed by man, there is one mode of netting-although many are practised-that is not much known, and seems to deserve especial notice from its destructive cha- 
racter, and the success with which it is frequently attended. Two or three poachers, disguised in respectable attire, travel about the country in a gig or dog-cart, accompanied by a single pointer or setter. One of the party alights at the outskirts of a village or country town, and proceeding to the public room of the nearest tavern, soon falls into conversation with some of the unsuspecting inhabitants; and passing himself off as ' an intelligent traveller,' or keen sportsman, about to pay a visit to the neighbouring Squire, soon obtains sufficient local information for his purpose. The other 'gentlemen' have in the mean time put up their horse and gig at an inn in a different quarter, and while discussing their brandy-and-water at the bar, have 'pumped' the landlord of all the news likely to prove useful to the fraternity. At a certain hour in the cvening the trio meet by appointment at some prearranged spot outside the village, and commence operations. After comparing notes, the most promising ground is selected. A dark night and rough weather are all in their favour. The steady old pointer, with a lantern round his neck, is turned into a stubble field, and a net of fine texture, but tough materials, is produced from a bag in which it has hitherto been closely packed. The light passes quickly across the ficld-now 
her'e, now there, like a 'Will-o'-the-Wisp'- as the sagacious dog quarters the ground rapidly, yet with as much care and precision as if he were working for a legitimate sportsman in open day. Suddenly it ceases to more, then advances slowly, stops, moves once more, and at last becomes stationary. Two of the men then take the net, and making a circuit until they arrive in front of the dog, shake out the meshes and place it in a proper position on the ground. Then standing opposite to each other, and holding either end of the string, they draw it slowly and noiselessly orer their quadruped ally-whose exact position is indicated by the lantern-frequently capturing at the same time an unsuspecting covey huddled together within a few inches of his nose. When this operation is carried on by experienced hands, an entire manor may be effectually stripped of partridges in an incredibly short space of time.

Although the quail (coturnix rulgaris) is known only as a summer visitor in most parts of England, yet in Ireland it has of late years been met with in considerable numbers during the winter. The London market is well supplied by quantities which are netted in France and sent alive to this country in the spring, where they are subsequently fattened for the table. Mr. Yarrell 
"found, on inquiry, that three thousand dozens have been purchased of the dealers by the London poulterers in one season." Most of these birds are males, which arrive from the south a few days before their partners, and are then decoyed into the net of the fowler by a wellimitated love note of the female. In Italy, Sicily, and Malta, they are still more numerous. As they fly by night, and generally close to the shore, long nets stretched on poles and extended orer the edge of the water are used in capturing them. One hundred thousand have been taken in a single day on the western coast of the Neapolitan territory. Great numbers are also killed, not only by regular sportsmen in the field, but by the motley population of the maritime villages on the Mediterranean, on the return of these migratory flocks to their winter quarters in Africa and Asia.

Mr. Yarrell has shown very ingeniously and satisfactorily, that there is every reason for believing that this-the only migratory species of quail-was the identical bird alluded to by the Psalmist, when it pleased the Almighty to furnish an ample supply of food to the famishing Israelites in the Wilderness: "He caused an east wind to blow in the heaven, and by His power $\mathrm{He}$ brought in the south wind. He rained flesh also 
upon them as dust, and feathered fowls like as the sand of the sea, and $\mathrm{He}$ let it fall in the midst of their camp round about their habitations; so they did eat and were well filled, for $\mathrm{He}$ gave them their own desire." * But a verse in a subsequent psalm even more distinctly points to the bird in question: "The people asked and He brought quails, and satisfied them with the bread of heaven." +

The introduction into this country of the redlegged partridge (perdix rubra), called also the Guernsey partridge and the French partridge, is a subject of regret with most sportsmen, especially in some parts of Norfolk, where the value of certain manors has been much deteriorated by its increase. In the first place, their extreme wildness, the rapidity with which they run, and their reluctance to take wing, are serious objections, as they not only spoil the dogs, but disappoint the shooter. In the next, even when killed-although their varied plumage, and especially the brilliant colour of the beaks and legs, cannot fail to be admired-yet the flesh is far inferior to that of any of our game-birds; incleed, in my opinion, scarcely to be distinguished from that of a guinea-fowl. Lastly, it has been found that in those districts where they have * Psalm lxxviji, 26-2!) + Psalm ev. 40. 
once obtained a firm footing, the disappearance of our indigenous partridge (perdix cinerea) has been the result: one to be regretted in every point of viev, sporting and culinary; for, with so many disadvantages, the foreigner does not possess a single redeeming quality to justify his usurpation.

It has often struck me as a singular fact in natural history, that when two species which are very closely allied are brought into juxtaposition, the weaker or less warlike will gradually give way to the other, and eventually become exceedingly rare or extinct. It would appear that similarity in habits, as well as a near relationship or affinity, is a necessary condition. The old English black rat (mus rattus), now almost unknown in his native land, had existed in this country for ages on good terms with the water rat (arvicola amphibius), and even with the common mousewith whom he was specifically allied-until the importation of the voracious grey rat (mus decumanus), to whose superior strength he was at last obliged to succumb. Thus the pheasant and the common partridge had prospered and increased on the same manor for centuries, until the latter was in some instances turned out of his inheritance by his continental relative. Two species - or rather varieties - of the common 
pheasant were originally introduced into this country; the Colchican from Asia Minor, and the ring-necked from China. The latter was the less robust of the two, and, besides other wellmarked distinctions of plumage, was characterised by a white ring round the neck. In process of time the Colchican increased and multiplied, while the Chinaman diminished in an equal ratio. It is said, however, that they bred freely together, and that the former, being the more powerful, gradually absorbed the other, while the white collar, that still adorns the necks of many of our modem pheasants, is all that remains of the plumage of their remote ancestors.

A friend of mine, whose residence adjoins an ancient building, under the massive caves of which great numbers of swifts annually rear their young, has observed that previous to their arrival in the beginning of May, the air orcrhead is filled with swallows and martins at all hours of the day, but as soon as the swifts have regularly taken possession of their summer quarters, their smaller congeners retire from the immediate neighbourhood; scarcely an individual is to be seen there during that seasou, while the shrill notes of the 'sereceher' resound from morning till night. About the middle of August the 
scene again changes. The swifts, the last to come, are the earliest to depart. The swallows once more make their appearance at 'the old hospital,' and continue to haunt the neighbourhood until, with the early frosts of October, they wing their way to the warmer regions of the southern hemisphere.

But the most remarkable example of this hostile tendency in animals of similar habits that has ever come under my own notice is that afforded by the chough and the jackdaw. I have elsewhere stated * that all my attempts to discorer the former species on the maritime coast of East Sussex-where it was once plentiful-were unsuccessful, nor could I ascertain to my satisfaction that a single specimen had been killed or seen for many years between Brighton and Beachy Head. Subsequent observation and inquiry have satisfied me that it has been banished by the jackdaw, whose numbers have palpably increased of late, and I believe that the same process is taking place on the cliffs of Dover, and on many parts of the southern coast of England. Some years ago, I found great numbers of choughs on the precipices of Caldy Island, off the coast of Pembrokeshire, and procured several specimens; but observed no jackdaws, although I saw two or * 'Ornithological Rambles in Sussex.' 
three pair of ravens who from time immemorialas at Beachy Head and Newhaven-had lived on excellent terms with the red-legged crow. But the daw has, I am told, since made his appearance there, and the graceful, slender bill of the chough can prove no match for the hard, conical beak of the grey-pated intruder. Indeed, I cannot help fancying that his doom is sealed: that, like the black rat, he must eventually give way to his more robust cousin and disappear from the cliffs of Albion; and thus, as too frequently happens in analogous circumstances among a nobler race of bipeds, the instinct of selfishness is often most powerfully developed by the ties of relationship and the clash of interests. 


\section{CHAPTER II.}

\section{"Quam facile accipiter saxo, sacer ales, ab alto Consequitur pennis sublimem in nube columbam, Comprensamque tenet, pedibusque eviscerat uncis Tum cruor et vulsæ labuntur ab æthere plumæ."}

VIRGII.

Pererrine Falcon - Truthfulness of Virgil's DeseriptionHaunts of the Peregrine - Hereditary Dominions Extensive Geographieal Distribution-Grouse and Peregrine-Ineident in Ireland-Paradise for Wild FowlThe Falcon's Wateh-tower-Disappointment-Change of Tactics-Attaek and Pursuit-Unsuccessful SroopChase continued-Death of the Nallard-The Rod and the Gun-Falcon and Teal.

How obriously has "the poet of nature" pointed to the peregrine in this passage; although certain learned systematists-in compliance, no doubt, with the imperious necessities and refinements of modern classification - have deprived him of one of his ancient titles (accipiter) and conferred it on the ignoble sparrowhawk, whose short wings and general conformation are better adapted to a denizen of the lower regions of the air and of the woods, than of the clouds or the 
precipice. Indeed, the description will hold good even as regards the favourite prey (columba) of the peregrine as every falconer knows, and as I can myself testify from personal obserration of his habits in a state of nature. On one of the most inaccessible ledges of a lofty maritime cliff on the north-west coast of Ireland a pair of these hawks have for many a long year been established: there have I frequently seen either of them plunge into the midst of a party of rock pigeons (columba livia), as they issued from a deep fissure in the face of the rock, and carry one off to their expectant family. Even the deadly clutch of the falcon at the moment that he grasps his quarry (comprensamque tenet) is true to the life, for although at other seasons, and in different situations, he usually fells his victim to the earth at a single blow, yet when foraging for his young he sclects from the motley inhabitants of the cliff one of moderate size-a pigeon, a puffin, a herring gull, a jackdaw, and occasionally even lis congener the kestrel-for a greater burden might impede his ascent to the eyrie; and it would be irretricrably lost if struck in the ordinary manner, and suffered to fall into the sea, perhaps many hundred feet below.

But although sacred to the gods (sacer ales) in classic times, and although to the rigour, 
courage, and docility of this noble bird our ancestors werc indebted for so large a share of their amusement-when his value was so great that in the reign of James the First a sum equivalent to a thousand pounds of our money was once given for a well-trained 'cast,' or pair-yet in these degenerate days he attracts but little notice, except where his occasional forays among grouse and partridges, or his wholesale depredations in the neighbourhood of decoys or on preserved lakes or ponds which are stocked with waterfowl, draws down the vengeance of the keeper and consigns him to the deadly trap. His eyrie too is occasionally plundered of its contents by some adventurous native, to whom the sale of the eggs or young may prove a fortunate speculation-and strange to say, the latter are less likely to find a purchaser now-a-days than the former-but although from the danger and difficulty of robbing the nest of the peregrine, and his now comparative worthlessness in a sporting point of view, together with his great wariness, his wonderful powers of wing, and the altitude at which he flies when searching for prey or performing his migrations, it might be expected that the species would have multiplied of late years, yet such does not appear to be the case. Increased attention on the part of ornithological 
obserrers may have been the means of revealing to the public the precise situation of the breeding place of a pair or so in most of our maritime counties, but nevertheless its existence was well known from time immemorial to the neighbouring inhabitants, and the traveller will always find, on prosecuting his inquiries, that the bird is honoured with some provincial title which has generally a direct reference to his prowess, the species on which he preys, his powers of flight, or to the locality itself. During my own wanderings I have invariably found this to be the case. I have seen peregrines at their eyries in Sussex, in the Isle of Wight, in Deronshire, on several parts of the coasts of North and South Wales, and in similar situations on the north-west, and south-west of Ireland; and although in some of the more remote of these places I might have occasionally flattered myself that I was the first actual discoverer of the fact, yet an ornithological chat with the natives was always sure to dispel the pleasing illusion. I found that the circumstance of the peregrine being established in their neighbourhood, and even the exact situation of the cyrie was well known to them, and the tradition of its having been similarly occupied in bygone times regularly handed down from their ancestors; and that 
the gull-hawk, the puffin-hawk, the duck-hawk, the sharp-winged hawk, the great blue hawk, the great hawk of Benbulben, the hawk of Cadia, \&c., invariably turned out to be the peregrine, whether the appellation was conveyed in the language of the Saxon, the ancient Briton, or the Celt.

The jealousy inherent in this bird and certain other raptores prompts them to expel their young from the neighbourhood of the nest as soon as they are able to provide for themselves, nor do they appear to tolerate the intrusion of another pair within many miles of the original stronghold. The extensive geographical distribution of the peregrine-for it has been found in all regions of the old and new worlds - together with its hardihood and enduring powers of flight, will account for these exiles being able to pitch their tents as colonists in any quarter of the globe. Certain it is, that many birds of the year, or 'passage hawks' as they were termed by our ancestors, to distinguish them from the 'eyas,' or bird taken from the eyrie, are known to appear in Holland, and different parts of the Continent, at the period of the southern autumnal migration, when the old falconers used to capture them by means of a net and a lure; and evidence is wanting to show that these birds ever return 
to their native country for the purpose of establishing themselves in the breeding season: yet the species must be almost omnipresent, for there is no nest of this falcon on the face of the earth, however remote or isolated, where, in the event of the death of one of the proprietors, the survivor will not succeed, generally within twentyfour hours, in finding a helpmate of the opposite sex, even when none but the original pair had up to that moment, perhaps, ever been observed in the neighbourhood.

Although the most formidable foe that any bird of moderate size could encounter, yet from its general partiality to an open country, the grouse and ptarmigan more frequently become its prey than any other species of British game; indeed, there are fow sportsmen who have shot much on the maritime moors of Scotland or Ireland, who could not recal to memory having seen some of their wounded birds struck and appropriated by the peregrine. I particularly remember an instance of the kind occurring to myself at the close of a grouse-shooting cxpedition, during which the fates had been decidedly unpropitions. It was one of those days that a sportsman abhors. The weather was sultry, and the seent bad. My dogss, als tired as myself, had dropped to heel, or now and then perhaps 
would suddenly start off on a bricf but ineffectual beat, and soon slink back to their former station. I was dragging ny weary limbs up the interminable slope of the last mountain that separated me from the lodge, and already anticipating the pleasure I should derive from the first glimpse of its chimneys in the valley beyond, when at an unexpected moment up sprang an old cock grouse from a little gully formed by the bed of a narrow stream, and wheeling over my head, away he went, 'cucketing' down the hill. I had only time for a random shot, which appeared merely to stagger him, and left a few feathers floating on the air. His flight, however, became gradually more laboured and difficult, and I had just raised my hands to my eyes in hopes of marking him down, when a shadow passing over the ground near my feet caused me to look upwards, and I saw a peregrine in rapid pursuit after my wounded bird, and gaining on him every moment. He had already cleared the valley in safety, and was evidently struggling to attain the shelter of the thick heather a few hundred yards up the opposite brow: but before he could reach it down she came and stopped his career in an instant. Having no wish to dispute the prize with my successful rival, or to be compelled afterwards to reascend the tedious hill 
which I had already surmounted, I made the best of my way, with a light bag, and a heavy gun, to my quarters at the lodge.

The myriads of gulls, puffins, guillemots, and razor-bills, which generally inhabit the same cliffs as the peregrine during the breeding-season, furnish a constant supply for itself and young during the summer; while the various flocks of wild ducks and water-fowl which visit this country on the approach of winter and haunt our inland lakes and estuaries on the coast, are frequently attended by a falcon of this species, who, on these occasions, finds himself in the midst of plenty, seldom failing to decimate his victims if allowed to remain sufficiently long without molestation. He usually abstains from striking his prey immediately orer the water, unless it should happen to be a teal or some other bird of small size. I had many opportunities, about two years ago, of observing the tactics of a fine fomale peregrine, who liad taken up her quarters for the winter in a secluded part of the clemesne of Parsontown, which was frequented by numbers of wild ducks. Two rivers, the Birr and the Brosna, here unite their waters. The former, rapid and turbid, rises in the distant mountains, and flows in a distinct current, until gradually lost in the dark yet transparent stream 
of the latter, which forms the boundary between Tipperary and King's County; and having its source in one of the vast bogs which extend through this part of Ireland, winds along, deep and silent, occasionally contracting itself as it hurries over some declivity, or stretching out now and then into wide sluggish pools, whose swampy banks, well fringed with beds of reeds and tall sedges, present a combination of everything that can be supposed to constitute a paradise for wild fowl during the winter.

Towards the close of a day's snipe-shooting, wishing to vary my bag with a few teal or wigeon, I approached this spot as stealthily as possible, just before the witching hour of twilight, when the shades of evening might favour my design, and before these birds had yet begun to quit this, their favourite haunt during the day, and scatter themselves over the bogs and morasses, their usual feeding places at night. By crawling along the side of the river, frequently on my hands and knees, keeping as near as possible to the margin, so as to avail myself of every inequality on the banks that might serve to mask my approachwhile at the same time the crackling of the dry sedges, as I wormed my way to the edge of the pool, might be drowned by the noise of a rapid just above-I at last found myself, though up to 
my knees in mud, and gradually sinking deeper and deeper, yet in a capital position for a family shot at the first party of ducks that might rise from the corer. Two mallards and a teal had alleady passed at a short distance, but I still reserved my fire, and at last clapping ny hands to give the alarm, a group of about a dozen sprang from within a few yards of me, and after blazing right and left into them, I could see that about half their number had dropped into the deepest part of the pool. The pointers were far away with an attendant, and having no retriever with me, I was obliged for the present to give up all idea of recovering them. The report of my gun had roused every bird in the neighbourhood, and up they started in all directions, chiefly ducks, wigeon, and teal, and provokingly wheeling round me within pistol-shot-a common occurrence, as every wild fowl shooter knows, under similar circumstances - while I was loading as quickly as I could, attained such an altitude by the time that operation was completed, that I had nothing left but to gaze at them as they swept aloft in wide and increasing circles, until they disappeared in the distance. Just at that instant I saw a peregrine falcon pass rapidly orerhead, in full pursuit of a batch which had cleased the opposite bank, and were evidently making the best of their way to 
Killeen Bog, about a mile off. She soon singled out one, a duck, who, as if aware of her danger, suddenly quitted her companions and endeavoured, by making a wide circuit, to attain a greatcr elevation. This manœuvre brought both her and the falcon again within view, and nearly over the spot where I was standing. Little did I think of my own dead or wounded birds in the absorbing anxiety of that moment. It was already growing dark, and I feared lest, after all, I should not be a witness to the termination of the chace. The falcon was just then above her quarry, in a favourable position for dealing the fatal stroke, but evidently waiting until the latter had cleared the banks of the river. Another moment and down she came, the sound of the blow reaching my ears distinctly, and as the duck tumbled through the air, head over heels, into the callows on the opposite side of the Brosna, I saw her conqueror descend with closed pinions just above her, until an intervening bank of sedges shut them both out from my view.

Of all the incidents which can occur in the wanderings of an ornithological sportsman, perhaps such an example as this of the powers of the falcon, unchecked by any artificial influences, is one of the most exciting. The performances of trained lawks, even under the most favour- 
able circumstances-although by many degrees the noblest sport in which man has ever indulged -yet to a certain degree are wanting in that unspeakable charm which attends the unrestrained operations of Nature and adds such a keen zest to the pursuits of her real votaries. Such at least have always been my own feelings, and acting under their impulse on this occasion, I abandoned both dog and gun for a couple of days, and relinquished for that time some of the best snipe-shooting in Ireland, for the sake of improving my acquaintance with the peregrine in her winter-quarters. Many a cold and anxious hour did I pass in a well-concealed position which commanded a good view of both banks of the pool not far from the junction of the two strcams. On one side spread the wide callows, or flooded meadows, stretching away towards the great bog of Killeen, with the fairy mountain of Knockshegowna* in the distance. Immediately in front, near the edge of the river, stood a dead tree, the topmost branch of which was the falcon's farourite resting-place. There she sat, erect and motionless, as if scorning to conceal her person, and in full reliance on her own irresistible powers whenever she chose to exert them.

* See Crofton Croker's 'Fairy Legends of the South of Ireland.' 
On the other side lay the grounds of the demesne watered by the upper river, here working its obscure way through the trees, many of which, uprooted by a late flood, were still floating on its surface; there rushing down an abrupt descent in a foaming cascade, or suddenly turning away into open ground and expanding into many a little bay where neither bush nor bramble could interfere with the tackle of the fly-fisher; while the grey turrets that flank the monster telescope, and the summit of the great tube itself, frowned over the tops of the trees near the castle.

I had waited long and anxiously, but although a duck or teal had passed now and then up the river, yet they failed as yet to rouse the attention of the imperturbable falcon. I noticed that they kept close to the surface of the water, especially as they neared the tall tree, and I almost fancied that the position of their enemy had not escaped their observation, for they always dropped suddenly into the stream close to the sedges. As my own place of concealment was too far from this retreat to admit of my flushing them again, without at the same time alarming the peregrine, I was obliged to leave matters to take their course, and thus the first day wore away without any satisfactory result. On the following morn- 
ing I adopted a more successful expedient. Despatching a light-footed native, who was well acquainted with all the favourite resorts of wildfowl among the labyrinthian recesses of a distant bog, through which the river meandered in its earlier course, I directed him to flush them from these haunts, while I resumed the post which I had occupied on the preceding day. For the first half-hour I was almost in despair; for the falcon was absent from her accustomed station, and I thought it not improbable that the operations of my coadjutor might have attracted her attention, and that she was perhaps at that very moment in full enjoyment of a chace which I was fated not to witness; but on looking up a few moments afterwards, there she sat, bolt upright as usual, and now every minute appeared an hour, as I strained my eyes continually in the direction from which I expected the arrival of the first detachment of ducks. Presently a cluster of dark spots appeared against the distant sky, gradually becoming more distinct, and sinking lower and lower as they neared the river, and at last keeping close to its surface, until they scudded by within a few yards of the commanding position of their enemy; who, probably from her reluctance to strike so large a quarry as a wild-duck, which she could not have clutched and carricd of with 
ease across the water, suffered them to pass unmolested. Next came two or three wigeons, which also ran the gauntlet with impunity. I now began to fancy that the appetite of the hawk must have been satisfied by some recent prey, or that perhaps the bird which I had seen her strike two days before might remain still uncligested. Just at that moment, however, a whistling of wings reached my ear; and I perceived a party of five or six wild ducks and a few teal approaching from a different direction, and nearly at right-angles to the course of the river, which they would apparently have reached at a point about thirty yards distant from the falcon's position. But she had no intention of allowing them such an advantage. In an instant she was on the wing, and had cut them off from their retreat. For a few seconds it seemed doubtful which was to be the victim, but one of the mallards having made a bolder dash at the stream than his companions, she seemed to mark him at once for destruction, while on his part he endeavoured to mount above his pursuer, and strained every nerve to accomplish this object by ascending spirally. In the meantime his comrades, availing themselves of this diversion in their favour, scudded down to the water and dashed at once into the friendly shelter of the seclges. Almost at the 
same instant the falcon made a swoop, but missing her quarry, she suddenly appeared a considerable distance below him, and now it seemed doubtful whether she could recover the advantage which she had lost by this unexpected failure. While she struggled upwards again in circular gyrations, and the mallard also made the best of his time to attain a higher elevation by executing a similar movement, but in a much wider curve, the two birds frequently seemed to be flying in opposite directions. The superior ease and rapidity, however, with which this manœurre was performed by the peregrine, soon convinced me that the result of the chace could not be doubtful; for the drake was now far from his favourite element, and as each successive evolution brought his enemy nearer and nearer, he seemed to relax in his efforts to ascend any higher, and at length turning his tail to the wind, away he went towards the bog of Killeen, trusting for escape to the rapidity of his flight, and closely pursued by the falcon. I felt that not a moment was to be lost if I rished to witness the dénouement; so, scrambling to the top of the bank, I was just in time to see the mallard tumbling headlong to the earth, while the falcon checking her downward carecr for a moment, as if to satisfy herself of the success of the stroke, 
dropped to the spot where he had fallen in the middle of a wide marsh, which I might have reached, by crossing the river at a higher point and making a circuit of about half a mile; but fearing that any closer inspection of her proceedings might tend to alarm her from her favourite haunts, and being quite satisfied with my share of the sport, I left her to discuss her well-earned prize without further interruption.

Many a subsequent visit, however, did I pay to the same spot before my return to England, frequently without seeing anything of the falcon, but occasionally finding myself amply rewarded by witnessing a clisplay of her powers. I always forbore from carrying my gun, lest I should be tempted to take a shot at some of the wild-forvl, and so disturb or perhaps scare away the peregrine, which was now the chief object of interest to me. I therefore employed my rod as an accessory to the day's sport, and although it was not the regular season for fly-fishing, yet on a muggy day, with 'a southerly wind and a cloudy sky,' I could always catch a good dish of wellflavoured trout from the upper stream, with the small black-midge or the dun-hackle, aided by fine tackle and a light hand. At other times the tantalizing rumours that reached me of some enormous pike having been scen, as he lay asleep 
in the recesses of the lower river, where he looked 'for all the world as big as a calf,' would tempt me to sally forth with the approved paraphernalia of trolling, to endearour to capture one of these monsters of the deep, who, I was assured, had baffled the arts of every previous visitor, and was destined to become a trophy of 'my honour's superior skill.' But although well aware that these leviathans existed only in the excited imagination of my informants, yet as their reputed whereabouts lay in the immediate vicinity of the falcon's retreat, I used to listen with apparent credulity to these pleasing fables; and if I failed to land a larger fish than any of my predecessors, yet I obtained at least the reputation of possessing a greater share of those indispensable qualifications of an angler, patience and perseverance. One afternoon especially I remember, when tired with want of sport, I found myself close to the spot where I had witnessed the last performance of the peregrine. Having waded into many parts of the stream during the morning, I had now the less hesitation about venturing into the sedges; so converting my trolling-rod into a beater's stick, I walked boldly into the swamp, and flushed several ducks, wigeon, teal, and a few pochards; pausing every now and then, when an opportunity occurred, to take a reconnoitring glance 
through the thick sedges. These glimpses, however, were so partial, and the ducks continued to rise so frequently without my being able to see them, that I at last struggled through as quickly as the nature of the ground would admit, and occasionally above my waist in the water. I was well repaid, however; for just as I cleared the cover, a small flock of teal, which had probably seen their enemy overhead and skulked before me to the edge of the reed bed, now sprang up at my feet and took wing with evident reluctance. Almost at the same instant I saw the falcon dash into the midst of them, as if she had fallen from the clouds, and in spite of the sudden and simultaneous whirl of the whole party towards the surface of the water, she succeeded in clutching one of them and carrying it across the pool, until she plunged with it into a thick clump of reeds and oziers, which clothed a little promontory that projected from the opposite side of the river.

Kind reader! I have perhaps cletained you too long on the banks of the Brosna, but my reminiscences of almost every spot that I have visited are so intimately associated with birds, that 'for the life of me' I could not help it. Had I been less of a sportsman or more of an astronomer, I might perhaps have edified you with marvellous, yet strictly veracious accounts of all that was revealed 
to my wondering eyes by the monster telescopeunder circumstances too which were unusually propitious for such observations. Of the stars or nebulæ I will say nothing; and of the queen of night herself I will merely remark, that I ascertained to my perfect satisfaction-in spite of Milton and Galileo to boot-that there were neither seas, lakes, rivers, woods, nor forests ' on her spotty globe, and that whatever may be the ordinary occupations or the favourite diversions of 'the man in the moon,' he is at any rate neither a fisherman nor an ornithologist. 


\section{CHAPTER III.}

\footnotetext{
"Long have I roamed through lands which are not nine, Adored the Alp and loved the Apennine; Revered Parnassus, and beheld the steep Jove's Ida and Olympus crown the deep."
}

BrRox.

The Woodcock-Summer and Winter Haunts-Decrease in England-Erroneous Reason assigned-The true Canse suggested-Slaughter on the Shores of the Mediterranean and the Adriatic-Clumber Spaniels-Colonel Parker's Notes-Shooting Expeditions to the Morea and Thessaly - Kornupeli-Aspect of the Conntry-Covers of Arbutus and Oleander-Gulf of Salonica- Reflections on the preceding Account - Protection recommended-Distribution in the British Islands-A Woodcock Battue in Ireland-The Common Snipc-The Solitary Snipe.

WHILE the pheasant, the partridge, and even the grouse, are exposed to considerable danger during the breeding-season; the woodcock is then in the enjoyment of comparative security; the great majority of the species having returned from their winter quarters in the British islands, and the swamps and orange-groves of Italy, Grecee, and Albania, to the vast unexplored forests of the North, where they rear their young 
and remain until the early frosts of the following autumn prompt them to repeat their southern migration.

It is singular enough that while too little attention is generally paid to the welfare of our game birds during the season of reproductionmore especially in preventing the depredations of the egg-stealer-and while their diminution is often exclusively and falsely ascribed to the practices of the night-shooter, or the unrestrained indulgence of the sportsman himself; the manifest decrease of woodcocks in many parts of Great Britain, of late years, has frequently been erroneously attributed to the wealthy gourmands of Stockholm and Christiania, who, it is alleged, evince the same predilection for the eggs of that bird as is shown in this country for those of the peewit, or lapwing, and we are told that many thousands are thus ammually sacrificed for the gratification of the Scandinavian epicure* On this subject Mr. Lloyd very properly says, "If persons, who entertain such an opinion, were to

* Since the above was written, 1 have been mueh pleased in perusing Mr. Thompson's reeently published work on the Birds of Ireland, to find my own opinion confirmed by Mr. Gcorge Matthews, who male a sporting excursion to Norway in 1843. "His notes state that the Norwegins secm to know Tittle about woodeocks, and in some plaees will not eat them." -Thompson's 'Natural IIistory of Ireland,' vol. ii. p. 25. 
see the almost boundless northern forests, they would probably think with me, that if the whole of the scanty population of that part of the world were to go out for the purpose, they would not be able to explore the hundredth part of the woods in the course of a year, and consequently they could not take or destroy any considerable number of eggs. If they are really scarcer than they were, it is doubless in some degree attributable to the greater number of persons who are in the habit of shooting at the present day than was the case formerly." *

There can be no doubt that this conjecture is correct, and the wholesale destruction by shooting does not take place in any part of the Scandinavian provinces-for Mr. Lloyd himself says that he never killed more than three in any one day during his residence in the north of Europe - but is carried on principally by British sportsmen, not only in their native land, but in various parts of the south of Europe; where their performances have occasionally been such as to 'astonish the natives,' and even to excite the surprise of many a veteran gunner at home.

I have had good woodcock-shooting in Wales and in Devonshire, and in some of the larger

* Jıloyd's 'Northern Field Sports.' 
covers of the Weald of Sussex, and have also formed one of a party who had tolerable sport in the neighbourhood of Rome and Terracina several years ago, but I have never seen so many killed as in Ireland. The most wholesale slaughter, however, of these birds would appear to be on the shores of the Mediterranean and of the Adriatic. Several British officers who have been quartered at Malta and the Ionian Islands have made expeditions to these wonderful swamps, and wild groves of orange, oleander, and arbutus, where the objects of their pursuit are found in incredible numbers. Many sporting members of the Royal Yacht Club too, tempted by the success of their friends, have been induced of late years to steer towards the South, instead of laying up their vessels at the close of the season; and to vary the charms of a winter cruise in the Mediterranean with woodcock and snipeshooting on the classic shores of Greece and Thessaly. Immense numbers are occasionally killed when the majority of the party are good shots, but it is generally admitted that the birds are not in such condition as those which are met with in the British islands, nor do they present so difficult a mark to the sportsman. A pack or team of wild spaniels is a great desideratum. The Clumber breed is the best, as their superior 
strength enables them to work their way through the jungles of blackthorn, where the more diminutive cocker would be soon baffled or exhausted. Half broken dogs are superior to those which are perfectly trained, as it is absolutely necessary that they should wander as far as possible from their keeper or huntsman, and bustle about in the tangled recesses of the cover, which would of course be inaccessible to him, while even the habit of crying or giving tongue-so serious a fault in the eyes of the sportsman at home-is considered a natural accomplishment of the highest value by the woodcock shooter in Greece.

Never having had the good fortune myself to pull a trigger on the banks of the Eurotas, to shoot snipes on the plain of Marathon, or to hear the echo of a double-barrel among the sacred heights of Ossa and Olympus, I am unable to speak of the subject from personal experience; but the kindness of a friend-Colonel Parker, 1st Life Guards-has enabled me in some measure to supply the deficiency, and to furnish the reader with information which, although it may excite very different feelings in their breasts, cannot fail to prove interesting to the ornithologist and the sportsman.

Colonel Parker's notes refer to an expedition which he made in the Louisa yacht, with his 
uncle, Sir Hyde Parker, and a few friends to the Morea and Thessaly, during the winter of 1844-5; and although the season was singularly unpropitious for the woodcock-shooter in the south of Greece, yet the records of the expedition show that besides the great variety of sport afforded by deer, hares, herons, bitterns, quails, pheasants, partridges, plovers, snipes, wild ducks, \&c., the number of woodcocks killed on several occasious was incomparably greater than the most fortunate and skilful party could procure in any district of the British islands with which I am acquainted. This communication also contains some account of the proceedings of two other parties who, during the same period, visited the Peloponnesus, as well as the shores of Albania, for a similar purpose, in the Diram and Flower of Yarrow yachts. As the testimony of an eye-witness is generally best conveyed in his own words, I gladly avail myself of Colonel Parker's permission to insert here a portion of his letter to myself, with extracts from the journal containing the result of each day's sport.

"You will perceive that the party in Albania had better shooting than in the Morea. This is quite dependent on the season. When the winters are mild, and there is not much snow on the mountains-as was the case in 1814-5- Al- 
bania affords the best sport; in the hard winters the Morea.

"Chiazenza, in the Morea, is the usual landing place from $Z$ ante, and twelve miles distant from it. Castel Tornese is the fortress above it. The ground here is moderately undulating, of a dry sandy soil; the covers formed by arbutus and bay-trees. In previous years this had been very good woodcock ground, but owing to the prevalence of fine weather this year, 1845, and absence of snow from the hills, the cocks had not come down so low. The same remark applies equally to several of the other shooting grounds that we visited.

"Komupeli on the Morea is to the northeast, about thirty miles from Chiazenza. From this anchorage we got our best shooting in the Morea. The ground of Palametochi showed the most sport. Near the convent of the above name are some small woods, with strong undercover of blackthorn, very difficult to work through. Adjacent to these is one very large wood, which, owing to the strength of the blackthorn, is nearly impossible to beat. We could not get the Clumber spaniels to go far into the cover away from their master, and the kirtled Greeks did not-in fact, could not-face the thorns, so that we did not half beat these covers, which will partly ac- 
count for our always finding, upon our return to these places, nearly as many cocks each time as the first. Part of this cover was low and marshy, but not very wet this year. The grounds of Maldonada, Cortiche, and Ali Tchelebi, are open plains with a good deal of fern and oaks, much like our English park scenery, with rivers and streams intersecting the plains, along which run narrow stripes of slight cover.

"Catacolo Bay in the Morea is the harbour to Pyrgos. Here the ground is varied. A good deal of it currant gardens, * very umpleasant to shoot in, the dwarf vines just reaching to your middle and catching you every moment. There are some wild, scrambling, small covers in the hollows - like the 'shaws' of Sussex - some wheatfields and some undulating sandy hills, with thick cover formed by arbutus, bays, and oleanders. The whole of this district - Catacolo, Pyrgos, and the Alpheus river-furnished but little sport this year from the great mildness of the season. Most days were like an English July. The sandy soil, on which grow the bay, arbutus, and oleander, had produeed in former

* Colonel Parker, no doubt, alludes to the Zante, or Corintl grape; the well known little fruit which, when dried and importerl into this conntry, is familiar to all housekeepers under the name of eurrants. 
and wetter seasons a good show of cocks, but this year they were thin.

"In the gulf of Sparta, on the plains of the Eurotas, we did not find much shooting, although there were some good low covers near the mouth of the river, and the banks of it in many places afford good shelter for game amidst its high reeds and rushes, which form a border, in some parts, of good depth.

"In the gulf of Salonica our first anchorage and shooting ground was Lentorochori, supposed to be the ancient Methone, at the siege of which place Philip of Macedon lost his right cye. It is on the plains of Thessaly. Our first day's shooting here produced a great variety of game. Upon landing we took a line nearly direct-without reference to the likelihood of the ground for game-to our intended quarters at Sphintza, a village twelve miles inland.

"Near the sea-shore there was a good deal of low blackthorn and recty and marshy cover. In this we first found the pheasants. The ground gradually ascended from the shore and partook of the character of flat park scenery - high fern with plenty of Velani oaks-none of very great size. In the fern we found pheasants and deer. Further up again were cultivated wheatlands, on which we found a good many partridges and 
hares. The partridges were of two kinds, the grey and the common brown.

"We descended again to the level of a small river, and shot along the line of it; a succession of wild, rushy, small covers in which we found our great variety of shooting. Pheasants, woodcocks, snipes, wild ducks, teal, all in the air at the same time. Neither the pheasants nor woodcocks differ in appearance or plumage from the English. We fancied the pheasants were drier than ours from want of good feeding, but we invariably put them into soup, and had therefore no fair trial of what a plain roasted one might have proved. The whole day we shot in sight of Pelion, Ossa, and Olympus.

"Our expedition into the interior did not answer our expectations, as the extracts from the journal will show. In fact we got among such large strong blackthorn covers that we could not work through them ourselves, neither would the Clumber spaniels face them, and I suspect that without 'stops' the Thessalian pheasants rum as fast as the Britisl. Three guns had again a very good day on their return to the yacht. $\Lambda$ s far as our experience went the shooting was ahways best nearest to the shore, and it is better not to go far inland. On the $3 \mathrm{~d}$ of February we got under weigh for the Vardar river, where we were told 
that we should find the best shooting in the gulf of Salonica, but the wind changed to 'on shore,' so we could not anchor there, and therefore stood on for Salonica - and here our shooting ended." *

That the number of woodcocks in England, and even in Ireland, has greatly decreased during the last twenty years, I take to be a fact established and admitted on all hands. The question that arises is to what cause the diminution of the species is to be ascribed. I think that from the actual observations of Mr. Lloyd and Mr. Matthews, to which I have already alluded, it does not arise from the persecution of the woodcock in his summer abode in the North of Europe; neither is it attributable to the number which fall to the gun of the sportsman in these islands during the shooting season. But I believe that such wholesale slaughter as that which Colonel Parker describes on the shores of

* The following extraet from the journals will show the result of six of the best days woodeock shooting.

Two days at Butrinto ........................ $\left\{\begin{array}{l}196 \\ 188\end{array}\right.$

Two days on the Fanara, or Acheron river ... $\left\{\begin{array}{l}110 \\ 193\end{array}\right.$

Two days on the Aehelous river ............. \{ $\left\{\begin{array}{l}168 \\ 171\end{array}\right.$

Grand total of six days ............. $\overline{1026}$ 
the Mediterranean is the chief cause of the birds being drained off from other quarters. The temperate climate of the southern countries of Europe will always afford strong attractions for the woodcock-whose food is so essentially derived from moist and marshy ground-during the winter months, at which period, in the inhospitable, regions of the north, the snow-clad earth and ice-covered waters bid defiarice to the efforts of his slender bill; and when arrived on those shores his further progress is possibly arrested by the philosophical reflection that having already attained a sufficient supply of food he might 'go further and fare worse;' which would certainly be the case should he adventure himself towards the interior of Africa! Although woodcocks have no doubt been occasionally found in Barbary and in Egypt, I think we are not to infer that they are by any means common in those countries; but on the consts of the Morea, Thessaly, Macedonia, and Albania, at $\Lambda$ thens, and in many parts of Italy, we know that they abound, and indeed they appear to be concentrated on the shores of the Mediterrancan during the winter months. Here they might probably be exposed to but little danger from the natives; but if our own countrymen, with all that ardour which characterizes an English sportsman, should 
engage in an amual crusade against them, and especially if there should be many such deadly shots as Colonel Parker and his friends, the species must manifestly be soon greatly reduced. Here too let me observe, that I think it would tend much to the preservation and increase of the woodcock in this country, if all proprietors would extend to it the same immunity which is so properly granted to our gallinaceous game birds, namely, not to allow it to be shot after the 1st of February. At present we know that it is customary in many counties to shoot hares and rabbits long after the pursuit of the pheasant has ceased, and on such occasions not only the keepers and farmers-who so far as I am interested would be most welcome to their share of the sport-but also many idlers about the neighbouring towns and villages, form a rabble rout with all the curs of the district at their heels, to drive the covers and exterminate certain quadrupeds and birds over which the law has not extended the agis of its protection. Amongst these the poor woodcock is a frequent martyr; and his fate is the more to be lamented, that being by general habit a migratory bird, the scattered examples that are found during the spring and summer had probably resolved to become permanent settlers and colonists amongst us, and had 
no doubt already paired and selected some secluded spot for their honeymoon, where, if spared, they would have nested and reared a brood. Now by encouraging the woodcock to do this, or at least by protecting him during the summer, we should go far to secure him as a constant resident, and the result would almost certainly be that in a few years the number in our covers would be materially increased. I am happy to say that some judicious game preservers in my neighbourhood have lately enforced this regulation, and with them, after the 1st of February, the woodcock is as sacred as the pheasant, and the consequence already is a palpable and undeniable increase in the number to be found on their properties during the regular shooting season.

The first arrival of these birds in England is on the eastern coast, during the latter part of October or early in November, when there is either little or no wind, or a favourable breeze from the north-east. After resting for a short time they resume their joumey towards the south-west; invariably revisiting, if possible, their haunts of the preceding year, and showing a strong preference for large woods, extensive heaths or swamps, and, above all, a moist and warm climate. Accordingly, after the early part of the season has passed away, they are more numerous in the 
southern and western than in the northern and eastern counties, more plentiful in Cornwall and in Devonshire than in any other part of England; and as the westem migration continues, under the influence of severe weather and protracted frosts, they abound in Ireland at the very period when they have almost disappeared from their usual haunts in this country, as was especially exemplified last year, 1849. In the early part of the season there was a fair sprinkling in a great wood of West Sussex, where they were suffered to remain undisturbed till a later period, when the covers were to be beaten for pheasants and hares. In the meantime a hard frost set in; the ground was covered with snow, the brooks and springs were frozen up, and at the termination of the grand day on which it was expected that we should bag at least twenty woodcocks, a solitary emaciated individual was to be seen at the end of a long row of pheasants. About the same time I received a letter from a friend in the county of Galway, informing me that the woodcock-shooting in the west of Ireland was better at that very moment than it had been for many preceding years.

It is almost unnecessary to remark that the sister island has long been famous for affording this sport in perfection. Indeed, my own carliest 
recollections of the gun are identified with it, and I had become a tolerable snipe and woodcock shooter before I had fired at a pheasant or eren seen one on the wing. The southern and western provinces are more celebrated than the northern and eastern, although I have had good sport in all of them. When the party is numerous, as is generally the case, a great number of cocks are killed in the large woods; twenty-five, thirty, and even forty couple being frequently the result of one day's sport. It is usual on such occasions to employ a host of beaters, whose proceedings are conducted upon a very different plan from that generally observed by the steady-going assistants of the pheasant-shooter in England. A heterogeneous army of men and boys-whose appearance might recal the description of Falstaff's ragged recruits at Corentry, -each furnished with a long pole, are drawn up at one side of the cover. The guns are either placed at intervals where the backward growtl of the brushwood may afford them the chance of getting a shot as they work through its mazes-for rides or alleys are but little known in these wild natural woods-or clse station themselves in different parts of the coppice, or on some eminence that commands a wider range of ricw-and these are the most knowing ones of the party- 
until at last the word is given to advance, when cach beater shouting 'Heigh cock!' at the very top of his roice, and laying his stick about him with all the energy of a thrasher, such an uninterrupted and discordant row ensues as might well start every cock within hearing from his place of concealment, and, in fact, causes numbers of those birds to spring prematurely from distant parts of the wood. Here, however, those wary gumners who have previously taken up their position on favourable heights possess a great advantage, and bring down many woodcocks as they fly in various directions, sometimes towards the beaters, sometimes in the face of the shooter, each struggling to escape the danger, but not knowing from which quarter it proceeds. $\mathrm{By}$ this time all discipline is at an end. Some of ' the boys,' having caught a glimpse of a falling woodcock in the distance, now fing away their poles and rush towards the spot, all anxious to be the first to pick up the bird and to congratulate the successful shooter on his dexterity; who, by the way, receives their compliments with marked ingratitude as they come rushing through the corcr, insist on keeping close to his person, and so, cffectually spoil his sport for the rest of the day. The same scene is probably enacting in ten different places at once. All order is at 
an end. Far away in the distance the cry of 'Heigh cock! heigh cock!' may now and then be heard during the intervals of the confusion from a solitary beater who as yet has listened to nothing but the sound of his own voice, and, instead of proceeding in a straight line, has made a wide circuit and now finds himself unexpectedly at the very point from which he started; while another who has independently advanced all alone, and at least half an hour too soon, to the opposite end of the wood, is flushing the cocks by dozens, without for a moment considering where the guns are, or which way the affrighted birds take, but delighted all the time at his own performance, while the distant sportsman inwardly curses him from his heart. Many a cunning old beater, too, who has been too long used to the thing to feel any excitement in it, drops quietly into the rear, and squatting under a holly-bush, lights his 'dudeen' with the utmost sang froid, regardless of all that is passing around him. It last the storm gradually subsides. A few dropping shots alone proceed at intervals from the outskirts of the wood. The shooters and beaters cmerge, one by one, at different sides, all eloquent on the subject of their own performances; not exeepting him of the dudeen, who exultingly points to 
sundry recent scratches on his face and shins, and swears that he "never liad such hard work in the whole coorse of his life.'

The great or solitary snipe (scolopax major) is less frequently met with here than on the continent. Its favourite breeding-places are in the north of Europe, and its autumnal line of migration lies rather to the eastward of the British islands. Among the hundreds of snipes that I have seen on the wing and killed in Ireland, I never could detect a single example of scolopax major, although until I became acquainted with the characteristic distinctions between this and the common snipe (scolopax gallinago), I used occasionally to fancy that I had obtained a specimen of the rarer bird when I had only bagged an unusually large or well-fed individual of the other species. It is sometimes found in the central and southern counties of England, but, as might be expected, occurs most frequently on the eastern coast. Some years ago, when shooting on the Pontine Marshes near Rome, in the early part of the winter, I killed three great snipes: their flight was different from that of the common bird; their bodies appeared much larger, and the wings shorter in proportion; they kept much closer to the ground, and did not-at least as far as my experience went-utter any cry, 
showing a similarity in these respects to their diminutive congener the jack-snipe (scolopax gallinula). In all the examples that I have seen, the bill was much shorter than in the common snipe; but the most obvions distinction consists in the brown marginal markings extending over the feathers of the breast and belly, nearly as low as the vent, while the same parts in the common species are of a pure white.

A friend of mine, who passed some time in the Austrian provinces to the south of the $\mathrm{Da}$ nube, told me that he frequently killed these birds during their autumnal migration, but that he rarely found them when the winter had set in. He remarked that they well deserve the title of 'solitary,' as he did not remember having ever sprung two at the same moment.

Although still abundant in some parts of Ireland, the common snipe is less generally distributed even there than formerly, while it has almost disappeared from many districts in England, where, about twenty years ago, it might have been considered plentiful. Indeed, the admirer of snipe-shooting will find comparatively little room for indulgence in his favourite pastime on this side of St. George's Chamel. He should betake himself to the great bogs and rushy swamps of the sister island, or the marshes of Italy and 
Greece. If anxious to have a preserve of these birds in this country, and if his love of the sport is sufficiently strong to induce him to make the necessary sacrifices, he must possess at the same time considerable territorial authority, and make up lis mind to run counter to the prevailing spirit of the age. He must refrain from an interference with nature, and boldly stem the torrent of modern innovation; but as the rage for agricultural improvement has lately increased to such a degree as to become a fashionable mania, and the proprietor of land may feel it no less his duty than his interest to increase the productive capabilities of his estates, it would perhaps be too much to expect that those who have the pecuniary means should practise such self-denial. Nevertheless, he who undertakes the drainage of a marsh, or the reclamation of a bog, at the same moment issues an 'order to quit,' not only to snipes, but to various species of grallatorial birds, resident as well as migratory. 


\title{
CHAPTER IV.
}

\author{
"Now, all amid the rigours of the year, \\ In the wild depth of winter, while without \\ The ceaseless winds blow ice, be my retreat \\ Between the groaning forest and the shore \\ Beat by the boundless multitude of wares."
}

Thomsox's Seasoxs.

Serere Season of 1838, 1839-Winter Scene on the Coast-

Preparations for an Expedition to Pagham Harbour Equipment-Irish Water Spaniel_Frozen Fish_Arrival at the Harbour-Floeks of Waterfowl-Wild SwansObservation and Plan of Operations - Mysterious Objeet - Formidable Rival - Ambuseade - Various speeies of Wild fowl - Suspense-The Great Gun-Oft at last Cripple Cliase-Retrieser and wounded Swan-The Hero of the Gun-boat-Return.

The severe winter of $1838-1839$, will be long remembered. 'The ornithologist and the wildfowlshooter, who fortunately happened to be then located on our southern shores, will recal to mind the acquisition of many a rare bird, and many a sporting expedition by day and niglit which it has never since fallen to his lot to realize. It is true we have had hard frosts and deep snows since then, and the winter which has just passed (1819-1850) 
has been unusually harsh and protracted: but whatever may have been the rigour of the season in more northern latitudes, it has never, at least in this part of England, reached such a point of intensity, or been attended with such results as marked the memorable period to which I have alluded.

Many feathered visitors of rare occurrence have certainly been met with lately in different parts of Great Britain, but they have been found more frequently in the interior of the island than on the southern coast, the cold having been sharp enough to drive them from their usual haunts, and to scatter them over the face of the country, but not sufficiently severe to induce them to continue their progress to the southward or to concentrate vast flocks of different species in the sheltered bays and estuaries of the chamnel.

Our evergreens, too, have escaped unhurt. The laurel groves exhibit their wonted verdure and luxuriance, and the bay-tree flourishes as before. Even the myrtle has withstood the chilling blasts of the last four months. How differently did they fare in 1S3S! While on our sandy soils they were perceptibly affected by the severity of the season, in the clay district of the weald they were killed outright, their foliage in the ensuing spring presenting the appearance of deciduous 
trees in the autumn; but as brown and brittle as if it had been parched by a burning sun.

$I$ resided during that winter in a cottage on the coast of Sussex about two miles to the west of Bognor. A small meadow lay in front of $\mathrm{my}$ windows, flanked on one side by a grove of stunted oaks, which were gradually disappearing before the inroads of the sea-for with spring-tides and stormy weather it rushed over the frail bank, tearing away the shingle and washing the projecting roots of the trees-and on the other by a wide expanse of the channel as far as the entrance to Pagham harbour, where the low flat coast appeared to extend suddenly to the southward until lost in the low promontory of Selsey Bill, above which the loftier outline of the Isle of Wight was visible in the distance.

About the middle of January the severity of the season appeared to have reached its climax. A cutting north-easter swept the water and carried the foam from the waves out of sight in an instant. All the larger features of the landscape seemed to have lost their natural colours, and were bathed in the extremes of light and shade. 'The surface of the earth, louses, banks, hedges, and corn-stacks were covered with snow. The sky was black and lowering, blended, as it were, into one vast cloud which looked still more 
gloomy in the distance as you faced the blast for a moment and peered into the eastern horizon. The sca was as dark as the sky, but its surface was broken by the white crests of the angry waves as they hurried towards the west, and thus relieved the obscurity on that side of the picture, while long files of various species of wilclducks, and small parties of cormorants and guillemots, might be seen scudding along close to the surface, but at a considerable distance from the shore, and every now and then a great blackbacked, or a herring gull, swept past, a few yards overhead, and flocks of sand-pipers skimmed rapidly along the margin of the beach in the same direction, all bound for the muddy flats and calm waters of Pagham Harbour.

I had made preparations over night for a regular field-day. The distance from my residence to the mouth of the haven was little more than a mile along the shore, and I was thus enabled -though not without a certain degree of labour, which, however, the intense cold rendered less irksome-to carry my own guns and ammunition, and at the same time to dispense with the services of an attendant, who, as experience had taught me, proves rather an incumbrance than an advantage on an expedition of this kind. My long duck-gun was now unpacked, and a heary double, 
weighing about eleven pounds, also put into requisition. A supply of Eley's cartridges suited to the calibre of each, with well-dried powder and waterproof caps, were stowed away in the larger pockets of my shooting-coat, while the smaller receptacles contained the minor sundries necessary to complete my equipment.

But although I willingly dispensed with the services of a biped attendant, I had one companion whose assistance was all in all to me on such occasions. This was an Irish water spaniel, whose education I had myself superintended in his native bogs and on the shores of the Atlantic, and whose sagacity, courage, and docility far surpassed those of any $\operatorname{dog}$ that $I$ have been able to procure in this country. He was rather larger than a setter, but his legs were shorter and stronger: his coat was curly, entirely of a liver colour, and of a fine silky texture; his ears long and pendulous; his feet were webbed like a duck's, to the rery toes; his face was smooth; his forehead broad and open. But the most striking feature was his eyes. Nothing in canine physiognomy could surpass the intelligence of their expression. They were of a bright golden colour, like those of a sparrowliawk: restless, and always on the more; indicating a joyous and adrenturous spirit, and an ardour and persererance, which 
indeed were prominent qualities in the character of their possessor.

Thus attended, and with a gun in each hand, like Robinson Crusoe, I hastened along the shore to Pagham. On my way I met with a singular evidence of the extreme intensity of the cold. Several fish of different kinds lay scattered at intervals on the beach, some dead, others dying, but all in a perfectly fresh state, lhaving been frozen in their rocky lairs at the bottom of the sea, and cast up by the waves. Some of these were of a species entirely new to me, and which I have never since met with. Their colours were indescribably beautiful. Every hue of the rainbow seemed to have been transferred to their scales.* My astonishment could hardly have been surpassed by that of the poor fisherman in the 'Arabian Nights,' when he drew forth the rariegated fish from the enchanted lake. I could not help regarding this discovery as a lucky omen for myself, so having selected half-a-dozen of the brightest, I concealed them under a lreap of pebbles, and continued on my way to the harbour.

Innumerable flights of small birds were col-

* Mr. Iarrell, to whom I related the cireumstance, conjectures that these fish belonged to the $1 \mathrm{~V}$ rasse family (lubriclec), some of the rarer species of which are remarkable for their beautiful irideseent colours. 
lected in the fields, and along the liedges, near the coast, consisting chiefly of larks, woodlarks, grey linnets, chaffinches and yellow hammers. So densely, indeed, were they crowded together that they seemed to be almost blended into one vast flock, which was continually reinforced by fresh arrivals from the interior, while every now and then a little male sparrow-hawk would suddenly appear on the outskirts of the army, and dashing into the midst, carry off with ease a starved and half-frozen victim: indeed, at one moment I observed several of these active little camp followers all busily plying their trade at the same time.

Not far from the narrow entrance to the harbour I found a coastguard-man perched on the summit of a mud wall, and attentively reconnoitring some distant object through his spy-glass. From this position he commanded an extensive view of the haven which-as it was now about full tide-spread like a great lake into the interior. The absence of large ressels, and indeed of almost all kinds of sailing craft, from this secluded spot, would at first strike a stranger with surprize, but at low water the mystery would be cleared up: the secne would then be entircly changed: a great extent of flat mud would be left by the receding waters, in the 
middle of which the shallow and devious channel might be pereeived winding like a silver thread on its way to the sea.

At this moment, however, the tide was at the highest, and a glance into the distance was suffcient to show me the object which had attracted the man's observation. Several flocks of wild fowl, apparently brent geese, wigeon, scaup ducks, pochards, and tufted ducks, were swimming near the further side of the estuary, while in the midst of these, like a naval squadron among a fleet of fishing boats, sailed a noble herd of wild swans. I soon perceived that they were too far from the shore to admit of my getting a shot at them, and had therefore no choice but either to wait patiently in expectation of some of the party separating from the main body and wandering up one of the narrow creeks on the opposite side of the harbour, when by taking a circuitous route, and availing myself of any intervening object that might project above the flat banks of the swamp, I might perhaps succeed in stalking them, or else to proceed in search of a less noble quarry. I at once chose the former alternative.

As I swept the shores of the estuary with the spy-glass, I had the satisfaction of observing that my sport was not likely to be anticipated by any 
wandering gumner, who might have perceived the birds already and perhaps venture on a random shot before I could commence operations, or even decide on the best mode of carrying them into effect. There was not a human being within sight, nor could I discover a single boat on the surface of the water. I had hardly congratulated myself on this fortunate circumstance, when a distant object arrested my attention. It looked at first like a plank of wood, or the trunk of a dead tree, as it floated slowly down a narrow creek, and seemed to be carried here and there at the mercy of the current; still there was something suspicious about it which prevented me from looking at anything else, and I continued to watch its movements with increasing anxiety.

On reaching the open water it turned round, apparently in an eddy of the tide, and gave me an opportunity of examining its outline as the broadsicle was turned towards me for an instant. There was nothing, however, in this hasty glimpse calculated to increase my alanm; on the contrary, I now felt more than ever convinced that I was looking at an inanimate log, and my only fear at this moment was that it might be drifted by the tide-which would soon begin to ebb-or by the irregular course of the channel, to that part of the harbour where the hoopers were still sailing 
in apparent security, and alarm them prematurcly. On a sudden, however, it seemed to alter its course and to move slowly under the shadow of the bank, or, as the sailors term it, to 'hug the shore:' it was apparently propelled by some hidden power, for it now no longer wheeled about, but advanced steadily with one end foremost, and as I watched its movements while it crept cautiously along, I fancied every now and then that I could distinguish the slight splash of a paddle, and my heart sank within me.

It was evidently the gun-boat of a wild-fowl shooter, and of one who was no novice in the craft; but when the first feeling of disappointment had passed away, I easily succeeded in persuading myself that I should derive more pleasure from witnessing his operations than in spoiling his sport-which would lave been the result of a premature movement on my part, for he was yet at least half a mile from the objects of his pursuit - but it occurred to me at the same moment that I might even manage to convert him into an unconscious but important ally in contributing to my-the jackal's - share of it. Taking, therefore, a hasty survey of the harbour and its shores, I saw that if I could contrive to conceal myself at a certain point on a long and narrow belt of shingle at some 
distance, over which the swans would probably fly when returning to the sea, I might perhaps have the good luck to intercept them. I lost no time in carrying out this plan: the coastguard-man ferried me across the mouth of the estuary, after which, by taking a wide circuit and availing myself of the nature of the ground where it was possible to mask my adrance, I succeeded at last in reaching the desired point, and having scraped a hole in the loose shingle sufficiently large to conceal myself and my dog in a crouching attitude, I placed my guns on either side of me, and now directed all my attention to the exciting scene in the harbour.

The hoopers were still there, surrounded by several flocks of wild-ducks, some five hundred yards from the position which I occupied, and about half that distance beyond them was the gun-boat, as harmless a looking object as could well be imagined, lying low in the water, and never for a moment attracting the attention of any of the devoted birds, who appeared to be perfectly at their ease and in the full enjoyment of repose and plenty after their long and stormy voyage. 'The brent geese and the wigeons were preening their feathers, while the scaup and tufted dueks were continually diving, or flapping their wings on their raturn to the surface before 
they again plunged to the bottom. The swans were also feeding, but in a different manner: with their long necks they explored the surface of the mud beneath, where, to judge from their perseverance and the number of tails that appeared at the same moment directed upwards, they must have discovered something well suited to their palates. I could also distinguish some of the less common species of anatide, among which the males of the smew and the golden-eye were conspicuous in their pied plumage. The sooty scoter too was there, but foraging by himself apart from the main body. All this time their concealed enemy was gradually lessening the distance between them and himself. Slowly and stealthily did he advance, nearer and nearer, until at last I expected every instant to hear the roar of the stanchion-gun, and fancied that he must be excessively dilatory or over-cautious, as minute after minute elapsed without the report reaching my ears. At last a bird rose from the crowd and flew directly towards me. I saw that it would pass tolerably near, and when in a few seconds afterwards I perceived that it was a male golden-eye within thirty yards of me, I almost forgot the important-though as yet passivepart I was enacting in the scene, and as I instinctively grasped my double-gun and raised the 
hammer, I felt tempted to pull the trigger. Prudence, however, prevailed, and I followed the example of my sagacious dog, who lay crouched at my side without moring a muscle of his limbs. He had seen the bird as well as myself, and his quick eye had detected my hasty movement, but his attention was again directed to the main body of water-fowl, several of which had at length taken alarm and were rising, one by one, from the water. It was an anxious moment. The swans were still there, but they had ceased to feed; their heads were turned towards me, and I soon perceived that the entire flotilla had gradually approached nearer to me. Now or never, thought I. I glanced rapidly at the advancing gun-boat-almost at the same instant a small puff of smoke issued from its further extremity, succeeded by a pigmy report, and up rose the entire host of water-fowl-swans and all-the snow-white plumage of the hoopers standing out in bold relief against the murky sky. Then a hugge volume of smoke and a bright flame burst from the prow, followed by the thunder of the great gun itself - off at last!-and as it cleared a passage through the winged mass between us, several of the motley crowd fell to rise no more: almost at the same instant the head and shoulders of a man were protruded from a covering of sea- 




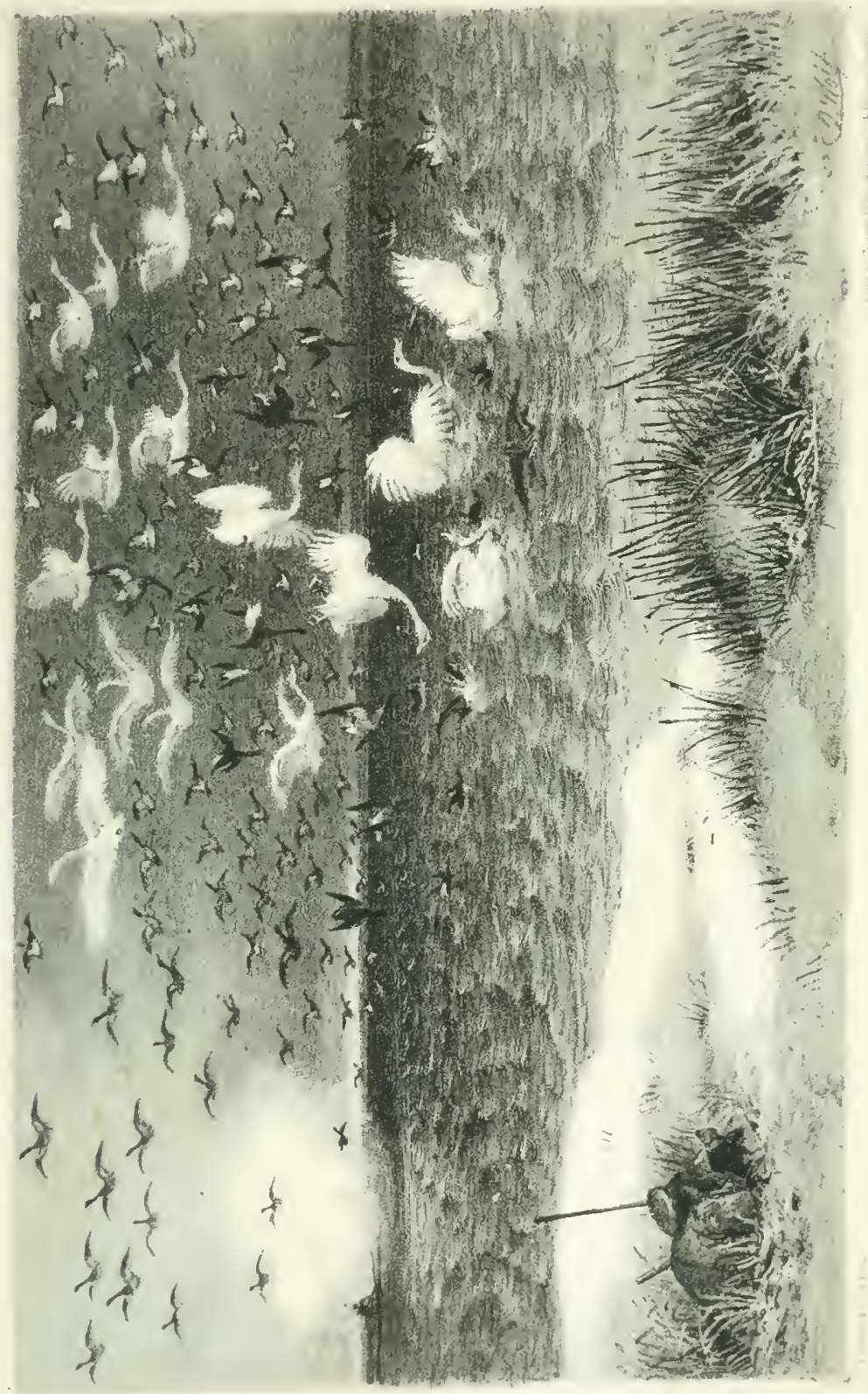



weed, under which he had hitherto been concealed, and the next moment he was vigorously plying his paddles in all the excitement of a regular cripple chase. My turn had at length arrived: restraining the ardour of my dog, who only waited for a word to take an active share in the pursuit, I turned my attention to a detachment of swans, about five in number, which had apparently escaped unhurt, and after wheeling once or twice over the bodies of their dead companions, uttering all the time their trumpetlike notes, were now gradually ascending and nearing my place of concealment. On they eame, but suddenly their leader seemed to have discovered my position and veered round in an opposite direction, followed by all except one, who, as he was passing overhead, fell a victim to my long gun. A brent goose almost at the same instant passed on the other side, and afforded an easy mark for the first barrel of my heavy double, while the second was discharged at a venture, but ineffectually, at a party of pochards - the last detachment of the fugitives, as they hurried back once more to the tempestuous but less treacherous waters of the channel.

On proceeding to the spot where my hooper had fallen, I found that it had been only winged, and that it had made its way down the further 
side of a sloping bank of shingle, which bounded this part of the harbour as far as the breakers: a few minutes more and it would have been far out to sea. Here my dog proved invaluable: plunging into the surf, he seized the swan by the disabled pinion, and after a long struggle, during which I frequently lost sight of both dog and bird, he landed it safely on the beach. It proved to be a male hooper, or wild-swan-cygnus ferus of authors.

I soon afterwards fell in with the hero of the gun-boat, and he gladly availed himself of $\mathrm{my}$ water-spaniel's assistance in retrieving many of his wounded ducks, which had struggled to the shore and had found concealment among the rushes on the borders of the muddy cores, with which this side of the harbour was indented. I then examined his spoil. He had killed six hoopers, scveral brent geese, and ncarly twenty ducks of different species, but none of any especial ornithological interest. He told me that he had but lately launched his punt on these waters, having been tempted by the severity of the season and the secluded situation of the harbour to migrate hither from the mud-flats of Poole and Lymington, which swarmed with rival gunners.

On my way home I skirted the opposite side of the estuary, and, as the tide had by this time 
elbed considerably, the crecks were occupied by flocks of curlews and sandpipers. By cautiously approaching these inlets, sometimes making a wide détour where the nature of the ground rendered it advisable, sometimes crawling on my hands and feet as I neared the margin, I was enabled to stalk several of the former birds successfully, and to get two or three 'family shots' at the latter. Before I reached the mouth of the haven, I found my baggage and artillery rather heavier than I could conveniently carry in the teeth of a north-eastern gale; so leaving my duck-gun and the greater part of my booty in charge of my friend, the coastguard-man, until the following day, I retraced my steps along the beach, not forgetting to pick up my fairy-fishes on the way, and slinging the hooper orer onc shoulder as a trophy of my sport. 


\section{CHAPTER V.}

"Officium autem quod ab eo ducitur hanc primum habet riam, quæ deducit ad conrenientiam conserrationemque naturæ, quam si sequemur ducem nunquam aberrabimus." -Cicero.

The Pheasant-Care and Attention necessary for his Increase and Welfare-Tame Pheasants-Outlying Nests-Eggs - Foster Mothers-Barn-door and Bantam Hens-Food of the Chicks-Ants' Eggs-Best Mode of Collecting them-Out-of-door Management of the Young Pheasants - 'The Gapes'-Prevention better than Cure-Singular Instance of its Malignity - Origin of the Disease, and consequent Inefficacy of ordinary Recipes-Colonel Montagu's Cure-Pheasants' Eggs-The Practice of Purchasing them reprehended - Importance of obtaining them in a Fresh State - Experiment to effect that Object - Aceident - Open Pheasantry - The RivalsThe Vietor ranquished-Nature the best Guide-Unexpeeted Result.

Althougn there is something repulsive to the true sportsman in the idea of encomaging by artificial means the oljects of his pursuit, yet there are so many and such peculiar circumstances connected with the nature of the pheasant that it may justly be considered an exception to the rule, and unless in certain highly 
faroured districts, remote from the busy haunts of men, and where considerable territorial authority still obtains, much care, experience, and attention are necessary at all stages of its existence for its welfare and preservation.

We must recollect that the pheasant is, strictly speaking, an exotic - as much so as the turkey or the guinea-fowl-and, although many centuries have elapsed since his first introduction to these islands, yet his absence from our farm yards and homesteads is not to be attributed to want of attention or spirit on the part of our breeders or farmers, but to an innate shyness and timidity which have hitherto foiled every effort to reclaim him thoroughly from a state of nature.

He therefore seems to occupy a position midway between the domesticated inhabitants of the fowl-yard and those wild denizens of the fields and the mountains, the partridge and the grouse; but while it should be the sportsman's object to elevate him as much as possible above the ignoble character of a poultry-bird, and to render him, as far as may be, fera naturâ, he must remember that in these days there are many serious obstacles to the welfare, nay even to the existence of the plieasant, in this thickly inhabited island, which can be counterbalanced 
only by having recourse to those artificial aids which long experience has taught us are absolutely necessary for the increase and maintenance of the species.

I have no intention here of inflicting on the reader a long essay on the best mode of hatching, rearing, and breeding pheasants, but as my own experience in these matters has been considerable, and, on a few points of importance, is somewhat at rariance with established usage; and as during the course of my experiments I have been led, from accidental circumstances, to adopt a plan for obtaining the eggs in a fresh state, more in accordance with nature than had hitherto been tried, and one moreover which has been attended with perfect success, I may be excused for deroting a few pages to the subject.

On the safe principle of leaving everything to nature where it is possible to do so, I am clearly of opinion that the eggs of pheasants, even when found in an outlying nest, slould not be taken for the purpose of placing them under barn-door hens to be hatched. No fostermother or nurse can compare with the natural parent; and it is surprising, indeed almost incredible-exeept to those who liave witnessed it-how frequently a hen pheasant will succeed in bringing up her brood in safety, although the 
nest may be placed in the most exposed and dangerous situation, within a few inches of a footpath traversed by hundreds of idle, bird-nesting boys, and in the immediate vicinity of a common or waste ground, where the authority of the landlord is a dead letter, and where, except for the safeguard which the quiet and unobtrusive colours of her plumage afford, the speedy detection of the bird would inevitably take place. Still there are circumstances under which it may be desirable to remove the eggs, and in these the prudent keeper must act according to his judgment. Should he, for instance, have reason to believe that the nest has been previously discorered by another party, who are only waiting until the full complement of eggs are laid, that they may pounce upon the prize with greater advantage, he will do well to place them quietly in the crown of his hat, and covering them with several handfuls of soft, dry grass, and lastly with his handkerchief, lodge them as soon as possible in a cool cellar, unless there is a sufficient number for a sitting, and a domestic hen ready for immediate incubation.

As the laying season approaches, it is advisable for the keeper to look out in all the neighbouring farm-yards and cottages for clean-legged barn-door hens. Some persons recommend ban- 
tams, but although they make excellent mothers, yet these diminutive birds are ineapable of covering more than eight pheasants' eggs efficiently, while sixteen or eighteen may safely be confided to the common dunghill fowl. The large Dorking, from its great size, is often a favourite with keepers; but I have seen so many cases of unintentional infanticide committed by these huge, clumsy-legged, five-toed matrons, that I cannot conseientiously recommend them. The gamehen, too, has her adrocates, and as a careful mother and watehful protector, none can surpass her; but woe to the unfortunate little members of any neighbouring eluteh of young pheasants that may venture unwittingly within the rails of her hutch: her hostility to them is equalled only by her attachment to her own brood. Now, as the lawn or piece of mowed grass on which the birds are reared is generally capable of accommodating several families, and as the young poults will oceasionally wander beyond the precincts of their own domicile into an adjoining stronghold, it is doubtful whether the iruculent propensities of these feathered Amazons are atoned for by their other good qualities.

I have generally found a cross between the common dunghill hen and the game fowl, the very best for the purpose; but where breeding is car- 
ried on on a large scale there is no use in being fastidious. The grand object is to find hens of any sort that are ready, or show indications of being soon ready, to sit. Those which have 'stolen nests' are to be preferred-that is to say, those which have of their own accord selected a spot for their nest in some out-of-the-way corner of a barn, stable, loft, or empty pig-stye. If the bird is already sitting on her eggs she should continue to do so until those of the pheasant are ready to be placed under her. The former may then be removed. Pheasants' eggs require about five or six days longer incubation than those of the common fowl, viz., about twenty-six days, and the appearance of the chick should be expected about the twenty-fourth day. Occasionally, as with domestic fowls, the internal coat of the shell will adhere to the young bird, and all its efforts to release itself will prove ineffectual. This is caused by a portion of the white of the egg having become dry from the admission of air through the opening which the little prisoner had previously made with his beak, and being thus suddenly changed into a gluey substance, the rudimentary feathers are apt to stick to the sides of the orifice. Under these circumstances it is aclvisable to assist nature. The aperture may be increased by the application of sereral gentle blows of any blunt 
substance, and the fracture may be extended until it comprises the whole circumference of the egg; after which, slowly and cautiously, the liberation of the captive may be gradually completed.

I am not now alluding to the system of bringing up young pheasants in aviaries, fowl-yarcls, or enclosures, but to the mode which 1 consider the best adapted for rearing, out of doors, and turning down at once in game preserves, a number of healthy poults during the summer, so that in the ensuing autumn they shall be in as full an enjoyment of liberty as is consistent with the nature of the country or the local system of preservation.

As soon as the young birds are hatched they should be left with the mother for a day and a night, during which time they require no food, nature having provided nutriment for their inmediate sustenance in the yolk of the egg, the residue of which has been recently drawn into the body of the chicken and absorbed, but the genial warmth of her body, under which they all nestle, is of the greatest importance to them. The first food that should be given them is ants' eggs. These arc, strictly speaking, the cocoons of the large rufous ant (formica rufa) which are tolerably plentiful in most great wonds during the summer. The nests are of considerable elevation, coneshaped, and constructed gene- 
rally of very small twigs and leaves of the Scotch fir. Some persons find it difficult to separate the eggs from the materials of the nest. The simplest mode is to place as much as may be requiredants, eggs, and all-in a bag or light sack, the mouth of which should be tied up. On reaching home a large white sheet should be spread on the grass, and a few green boughs placed round it on the inside, over which the outer edge of the sheet should be lightly turned; this should be done during sunshine. The contents of the bag should then be emptied into the middle, and shaken out so as to expose the eggs to the light. In a moment, forgetting all considerations of personal safety, these interesting little insects set about removing their precious charge - the cocoons - from the injurious rays of the sun, and rapidly convey them under the shady cover afforded by the foliage of the boughs near the margin of the sheet. In less than ten minutes the work will be completed. It is only necessary then to remove the branches, and the eggs, or cocoons, may be collected by handfuls, unencumbered with sticks, leaves, or any sort of rubbish.

Many kinds of farinaceous and vegetable food have been recommended for young pheasants when they are a little older, such as the green 
tops of barley, leeks, boiled rice, Emden groats, oatmeal, \&zc. They are all excellent, but I am satisfied that they are almost always given at too early a period. In a state of nature their food for a long time would be wholly insectile. Now as it is not in our power to procure the quantity and variety of small insects and larva which the motherbird so perseveringly and patiently finds for them, we are obliged to have recourse to ants' eggs, as easily accessible and furnishing a considerable supply of the necessary sort of aliment within a small compass. Ants' eggs, indeed, are the right hand of the keeper when bringing up young pheasants; without them he may almost despair of success, and with a good stock of them his birds will thrive apace and escape many diseases to which they would otherwise be continually liable.

A large sward of smooth green turf, planted here and there with shrubs and evergreens; or a small meadow, newly mown on purpose, near the keeper's housc, and bounded by a coppice or plantation, afford good sites for the nursery. On this the coops should be placed at intervals of several yards from cach other. These should be shaped like the roof of a cottage, open beneath, boarded at the back and at each gable end, but with rails in front sufliciently wide to 
adnit of the ingress and egress of the ehicks, yet so close as to prevent the hen from quitting it. A lid to fit this part of the coop, or 'rip,' should be laid over it at sunset every erening. This will prevent the unwelcome intrusion of stoats and weasels, and though last, not least in iniquity, of rats. It should be placed in its proper position as gently as possible so as not to alarm the young pheasants, who, as they advance towards maturity, become exceeding shy and wary, start from underneath the wings of the hen at the slightest alarm and betake themselves to the nearest cover, from which it is frequently a long time before they again issue, and if the shades of evening have fallen in the mean time, they have no little difficulty in retracing their steps to their own habitation.

The coops should be moved morning and evening, as the hen ought to have a fresh piece of greensward underneath her twice every day. Attention to this point is of the greatest importance. She may be fed with barley, rye, or oats-the first is the best-which should be thrown inside the coop, but the ants' eggs, and whatever is intended exclusively as food for the chicks, ought to be placed just on the outside, or she would have no compunction in appropriating the greater portion of it to herself. When about a week 
or ten days old, Emden groats and coarse Scotch oatmeal may be mixed with the ants' eggs, and curds made from fresh milk with alum, are an excellent addition. If ants' egg's cannot be procured in sufficient quantities, gentles should occasionally be given, which may be obtained in the following manner. An ox-liver, a sheep's head and pluck, or the leg of a horse, should be suspended from the bough of a tree in a warm sheltered situation. Beneath this a wide shallow tub, half filled with bran, should be placed. In a short time the meat will be thoroughly flyblown, and in a few more days it will be covered with maggots, or gentles, which will continue to drop into the tub, where they soon become cleaned and purged in the bran. A large spoon or saucer may be used for removing them. Next to ants' eggrs, these perhaps constitute the best 'standing dish' for young pheasants, and have besides the advantage of being within the reach of every brecder. Wasps' nests, containing the larva and pupx, may be procured withont difficulty at a later period of the season, and afford a most acceptable treat. If the supply of these should be too great for immediate nse, or if it should be thought advisable to economize the stock, it will be necessary to bake them for a short time in an oven. 'This will prevent the 
larve and nymphs from coming to maturity -in fact, kill them-and the contents of the combs will keep for some weeks afterwards. Hempseed, crushed and mingled with oatmeal, should be given when about to wean them from an insect diet. Hard-boiled eggs also form a useful addition, and may be mixed for a long time with their ordinary farinaceous food.

A supply of fresh water is of importance. It may be placed in wide shallow saucers, which should be partly insicle and partly outside the coop, so as to be within reach of both the hens and the chicks. The best sort are made of common tile clay, in a series of concentric ridges, each about half an inch wide. These hold a sufficient quantity of water, and by enabling the chicks to walk through them without wetting their feathers, are superior to a common plate or pan. They may be had at most country grocers' or earthenware shops.

Young pheasants are subject to a kind of diarrhœa, which often proves fatal. If the disease be taken in time, boiled rice and milk, in lieu of any other diet, will generally effect a cure. To these chalk may be added, to counteract the acidity which attends this complaint, and should the symptoms be very violent, a small quantity of alum, as an astringent. 
But the most formidable disease from which the young pheasant suffers, is that known by the name of 'the gapes'-so termed from the frequent gasping efforts of the bird to inhale a mouthful of air. Chickens and turkeys are equally liable to be affected by it, and it may be remarked that a situation which has been used for many successive seasons as a nursery ground is more apt to be visited with this plague than one which has only recently been so employed. Indeed, I have observed that it seldom makes its appearance on a lawn or meadow during the first season of its occupation, and, therefore, where practicable, it is most strongly to be recommended that fresh ground should be applied to the purpose every year, and when this cannot be done, that a quantity of common salt should be thrown broadcast over the surface of the earth, after the birds have left it in the autumn. This scourge is not confined to poultry-yards and aviaries. About the latter end of June, 1848, I visited the pheasant nursery of a friend, whose head-keeper is perhaps one of the most intelligent of his calling, and has had more than half a century of experience in rearing tame pheasants. Nothing could exceed the beauty and the natural advantages of the spot. It was in a large orchard, with a sonthern aspect, near a garden well fenced and secure 
from the attacks of vermin. 'The green turf was kept carefully mowed, and the old apple-trees were sufficiently far apart to admit the sunshine, while their spreading boughs afforded a cool shelter to the young broods during the midday heats. About fifteen or twenty coops were scattered here and there, each containing a steady business-looking barn-door hen. Here, was one whose sole thoughts seemed to be engrossed with the care of her newly hatched family, who were snugly nestled under her capacious wings, while she seemed to puff herself out to the greatest possible dimensions, that the prying stranger might not catch even a glimpse of her precious little ones. There, was another, apparently in all the agonies of despair at the sudden flight of her truant charge, which, having just begun to learn the use of their wings, had fluttered into a clump of raspberry bushes in alarm at my sudden approach. There again, was another in the full enjoyment of maternal pride, as her 'happy family' ran in and out under the bars of the coop and jumped nimbly upon her back or sat basking between her shoulders. Ants' eggs were in abundance, and a goodly shower of gentles were constantly dropping from the corpses of two grim-looking cats, suspended from the branch of a pear-tree, who seemed thus, as 
it were, condemned to make some atonement for their manifold sins against the game-laws. Erery thing, in short, appeared to be prosperous, and about two hundred young pheasants were in perfect enjoyment of health and happiness in that favoured spot. A month elapsed before I visited the place again. The old hens indeed were there, but looking shabby and disconsolate, while a few sickly, gawky poults sat near them, with half-closed eyes and ruffled plumage, starting every now and then from an apparent state of stupor, and with open beaks and necks extended to the utmost, making a long spasmodic effort to breathe; while others, among whom the disease had as yet fallen less heavily, or who were perhaps recovering from its effects, were lazily passing between the rails of their coops or lounging outside in the sunshine, like the convalescents of a fever hospital. Three-fourths of their number had been swept away during the last fortnight by that dreadful scourge, the gapes, which, like eertain diseases that affect the human subject, seemed to have been engendered and fostered by excessive population within a limited district. The place had been devoted to the same purpose year after year, and the germs of the disorder, although occasionally dormant for a season, were always ready to break out at 
an unexpected moment with increased virulence.

Dissection has proved that the latent cause of this malady is a minute worm of the genus fasciola, which is found adhering to the internal part of the windpipe or trachea. Occasionally it may be discovered just within the aperture of the glottis, but generally it is more than half-way down, and not unfrequently near the bifurcation of the trachea. It adheres closely to the internal membrane by means of two suckers, is almost devoid of the power of motion, and altogether has rather the appearance of a small artery or red muscle than of a worm. Nevertheless, it is obviously the immediate cause of this distemper and of death itself, which is the result of suffocation from the highly inflamed state of the respiratory apparatus. To any one aware of this fact, it is erident that all attempted modes of cure which have reference to the digestive organs must be utterly hopeless, and yet there is hardly a gamekecper or henwife who does not boast of some original nostrum, which, being administered as food or drink, must of course pass through the œesophagus, or gullet, into the stomach. I have seen such remedies tried in hundreds of cases, but, of course, without success. Tracheotomy, and the removal of the worm-if such a delicate 
operation could be performed on so tender a subject as a young pheasant without of itself causing death-might be attended with happy results. I have witnessed its failure even when attempted by a master-hand, and that of many other ingenious mechanical contrivances to effect the same object. Hitherto, I am convinced that no specific has been discorered, and that the method recommended by Colonel Montagu is the only one that promises a chance of success. This is fumigation by tobacco-smoke, under the influence of which the poults should remain long enough to ensure the death of the tracheal worm, while its effects on themselves should not exceed the limits of stupefaction. Here, in fact, is the difficulty. The experiment should, if possible, be tried at an early stage of the disease. I have myself frequently performed it with success mnder such circumstances, and have as often failed after it had become firmly established, and when the constitution of the birds liad been weakened by its ravages. Having said thus much on this pheasant plague, I shall not allude to any of their minor diseases, which, indeed, if taken collectively, are not of a hundredth part of the inportance of 'the gapes;' but as I firmly believe the tobacco-smoke cure to be the only one that holds out a probability of suceess, and as much 
care and attention to all the details of the operation are absolutely necessary, to enable the practitioner to steer the middle course between stupefaction and suffocation, I shall here transcribe it in the words of Colonel Montagu himself, to whose intelligence and ingenuity we are indebted for the valuable discovery :-

"In order to administer this fumigation in sufficient quantity, there is some care required that the chickens, which must be confined in a close vessel, are not suffocated. We have repeated this operation with the utmost success by confining the diseased chickens in a box, with a door on one side about half the height of the box, with its hinges so placed as to open downwards. By this means the interior can be examined from time to time, in order to observe the density of the smoke and the state of the chickens. To a person in the habit of smoking tobacco there is no difficulty in lighting a pipe, and by introducing the bowl through an aperture, the smoke may be blown in till it appears considerably dense, which must be examined every two or three minutes.

"When any of the chickens become stupefied by the narcotic quality of the fumes of the tobacco, the operation of blowing the pipe should cease; and as fresh air will rush in when the 
door is opened, there will be no danger of suffocation. If, however, any should appear to be more exhausted than the rest, or than is requisite, they should be taken out, and they will soon recover when removed from the smoke. We have found that the longer the chickens are confined in the smoke the better, but that a certain degree of density is required to destroy the worms by its caustic quality. As dense a smoke, therefore, as the chickens can continue to exist in is best, and the criterion is stupefaction and the loss of the use of their legs; when that effect appears, no more smoke should be introduced.

"As soon, however, as the chickens recorer the use of their legs, they may be suffered to remain in the fumigating box for two or three hours; but remembering that the inhaling of a large quantity of smoke in half an hour will be more effectual than a whole day confined in a small quantity." *

An object of the first importance with all who arc anxious to incrcase their stock of pheasants, is to procure a good supply of fresh eggs. I have already expressed an opinion that even the outlying nests, if not exposed to the most imminent

* Supplement to the 'Ornithological Dictionary'-Article 'Pleasant.' 
risk of discovery, should be allowed to take their chance, trusting to the natural instincts of the female bird to enable her to escape detection, while at the same time no pains should be spared in thwarting the illegal depredations of those idle vagabonds who liaunt the outskirts of every manor. An adequate number of eggs, therefore, from his own beat is not to be expected by any proprictor, and as to purchasing them from persons in his neighbourhood, or eren at a distance, the practice is so reprehensible in every point of view that it may almost appear umecessary to stigmatize it as it cleserves. It is alike unworthy of a gentleman or a sportsman, nay, even of an honest man; and yet it cannot be denied that there are many who have a fair claim to all of these characters, in their general conduct, their bearing in the field, and the ordinary tenor of their dealings, who do not scruple to purchase pheasants' eggs every year, thus blindly shutting their eyes to the nature of the transaction, and indirectly encouraging a system of poaching far more destructive and degrading than the practices of the night-shooter whom they themselves, a few months afterwards, have but little compunction in consigning to the tender mercies of the treadmill.

But apart from these considerations, it must 
be observed that the eggs obtained through these ambiguous and uncertain channels are frequently good for nothing. Half the number are either addled or contain dead chicks, in different stages of development, having been abstracted, probably many days before, from various nests, and kept perhaps in a cupboard or underneath a bed in the stuffy cabin of the robber until a sufficient number had been collected to ensure a profitable day's sale.

An efficient plan for procuring the eggs in a fresh state may be adopted by any person residing in the country who can afford to devote to the purpose a well fenced piece of ground, in a quiet situation, with a dry soil and a southern aspect. The wall or wooden fence ought to be high, and the top entirely covered with a net, which may be supported in the centre by one or more tall poles. A few heaps of dead bushes or dry faggots should be placed in each corner and in different parts of the enclosure, and a supply of fresh water must not be forgotten. Here may be lodged from twenty to thirty pheasants, according to the dimensions of the place. It is absolutely necessary that they should be what are called 'tame bred birds,' that is, birds which have been hatched and reared under domestic hens, as those which are netted or caught in a 
wild state will always prove inefficient layers. The hen pheasant is in her prime at two years' old. About the fourth season her oviparous powers begin to decline, although her maternal qualifications in other respects do not deteriorate until a much later period. It is, therefore, of consequence to enlist occasionally a few recruits to supply the place of those females who have completed their third year, and who may then be set at large in the preserves. There are various opinions as to the number of hens that should be allotted to one cock. Some persons allow as many as five or six. My own conviction, the result of long experience, is that three are sufficient and that the admission of a greater number will entail the frequent occurrence of unproductive eggs, although in a state of nature the relative proportion of the sexes might vary considerably. Let us suppose then that twentyone hens and seven cocks are turned into this enclosure. They may be fed with barley, beans, peas, rice, or oats; boiled potatoes, Jerusalem artichokes, and Swedish turnips. A large heap of dry sand, protected by a shed from the rain, must also be provided, in which they are fond of dusting themselves-indecd, no pheasantry should! be without one-as they are by this means enabled to rid themselves of vast quantities of para- 
sitic animalculæ, which prove so detrimental to the health of all gallinaceous birds. The pheasants may be allowed to remain together until March, when the cocks will begin to evince frequent signs of pugnacity-the first indication of the approaching breeding season. The large enclosure is then to be divided. into seven lesser compartments, by means of tall hurdles or wattles, to all of which the keeper should have ready access. Three hens and one cock may be placed in each of these, water and food should be regularly supplied once, and but once, a day : at the same time the attendant will have the opportunity of removing any eggs that may have been laid druing the previous twenty-four hours, and these he ought at once to deposit in a cool cellar until a sufficient number have been collected for 'a sitting,' which should be placed under a domestic hen. The quantity which hen-pheasants will lay during a season in this qualified state of captivity is very great. The larger the compartments in which they are kept at that time the better, so as to admit of sufficient room, fresh air, a heap of bushes, and a mound of sand in each. I laad been for some years in the habit of kecping pheasants in a modcratcly sized establishment, such as I luave described, when an accident to the netted roof, which indecd was 
almost destroyed by a severe storm, induced me in the following spring to try an experiment which was attended with unexpected results.

All my pheasants having escaped on the night of the accident, I was obliged to commence operations de novo, and, to avoid the expense of netting, I pinioned fifteen tame-bred poults,eleven hens and four cocks, - with which the kindness of a neighbouring friend supplied me, and turned them all into the enclosure. The operation of pinioning consists in amputating the forehand or pinion of one wing at the carpal joint. The bird is never able afterwards to ascend in flight more than two or three feet from the ground, and therefore escape from an enclosure such as I have described would be impossible.* The wounds soon healed, the birds enjoyed excellent health through the winter, and in the following March, when the males began to exhibit the usual symptoms of pugnacity, I was preparing to locate them in their respective compartments for the season, when I was unexpectedly obliged to leave home, and directed that the pheasantry should remain in statu quo during my absence. On my return, how changed was the state of affairs! Love and war had been rumning

* Birds thus pinioned are of eourse unfit fur subsequent liberation in the euvers. 
riot within its once peaceful precinets. Three of the four cock-birds were completely hors de combat. One of them, indeed, was dying, two were sererely lacerated, but the fourth, who, like the surviving Horatius in the combat with the Curiatii, had probably vanquished all his rivals in detail, appeared, like his classical prototype, perfectly uninjured, and strutted in all the pomp and pride of a conqueror among a crowd of hens, who seemed to regard matters with perfect equanimity, passing with contemptuous indifference their unfortunate knights-errant, as they sat moping on the ground with their heads buried in the friendly shelter of the bushes, but following obediently in the wake of the rictor, and evidently disposed to admit to the full extent that ' none but the brave deserve the fair.'

I should have mentioned that the grounds in the neighbourhood of the enclosure were stocked with wild pheasants, most of which had once been ' tame-bred birds,' and-although always exhibiting the imnate timidity of the species on any sudden alarm - evinced an attachment to the place in which they had been reared, and continued to ham the garden and erergreens during the greater part of the year. As I had now no opportunity of procuring any pinioned male pheasants to supply the place of the three discomfited 
heroes, I allowed matters to take their chance, fully prepared to find that most of my eggs would prove unproductire and almost inclined to break up the pheasantry altogether, but my halfformed intention was suddenly arrested by a new turn in the aspect of affairs. On entering the enclosure one morning, I was surprised to see a fine old cock-pheasant, with a tail of portentous length, take wing from among the midst of the hens and, with a protracted crow of triumph, fly orer the fence into the evergreens beyond. But where was Horatius? Alas! his days were numbered. He had found his match at last. After a long search, I discovered him squatted in a corner, his once brilliant plumage tom and covered with blood. One eye was closed; the other was completely extinguished. His neck was entirely plucked, and as bare as a vulture's. His crimson cheeks were sadly lacerated. His head was absolutely scalped, and where a pair of purple egrets had lately been so proudly erected, a bare skull was now alone visible. Poor fellow! he died the same evening. The rest may be briefly told. Day after day did the conqueror visit his newly acquired territory, and many a youthful rival, too prudent to come into close quarters with the long-spurred tyrant, would pay a stolen visit to his seraglio during his absence 
and win the farours of his fickle fair ones. I obtained an immense number of eggs during that season, which proved unusually productive. No further care was necessary than to provide the birds with a sufficiency of food and to remove the eggs every day-which, by the way, were never deposited in a nest, but dropped here and there in different parts of the enclosure. Thus, from what I regarded at the time as a succession of untoward accidents, I became acquainted with the most effectual, because the most natural way of keeping hen-pheasants with a view to obtaining a constant and ample supply of prolific eggs during the breeding-season. Every gamekeeper's cottage in the heart of a preserve must possess in its neighbourhood much greater facilities for the undertaking than were within my own reach. My expectations, I confess, were far exceeded; and if what I have now written should be the means of inducing others to follow my example on a larger scale, I shall rejoice, not only in having becn fortunate enough to confer a real bencfit on the preservers of game, but still more in having becn cnabled-though indirectly-to inflict 'a heavy blow and great discouragement' on the nefarious traffic of the egg-stealer-the most destructive and umpardonable of all the numerous devices of modern poaching. 


\section{CHAP'TER VI.}

“ Nay, I am for all waters."-SuAKSPEARE.

Various Species of Wild Geese-Grey-lag and White-fronted - Distinguishing Charaeters - Origin of the Dumestie Stock-Bean Gonse - Pink-footed Goose - Berniele Brent Goose - Shickdrake - Foreign Ducks and Geese unadrisedly admitted into the British Fanna - Probable Canse of the Error - Ducks on the British Consts Diversity of Haunts, Habits, Food and Structure Decoys - Wild Fowl Shooting - Young Water Fowl devoured by Pike-The 'Bird-fly'-Observation.

THere are about five or six species of wild geese usually met with by the coast shooter in the British islands; one of the most uncommon of which, if not the very rarest, is the grey lag or grey legged goose (anser ferus), once called the common wild goose, and supposed to be the origin of our reclaimed bird. Yet there is good reason for believing that a nearly allied species of far more frequent occurrence, although bearing a gencral resemblance in size, form and plumage - the white-fronted goose (anser albifrons) has had nearly an equal share in founding the 
domestic stock. The distinguishing characters of the first named are frequently met with among our tame birds, whose colours approximate to those of the wild type; such as the wings being of a lighter tint than the upper parts of the body, as well as in the pale flesh colour of the legs, while others again have the orange coloured legs and white forehead of anser albifrons. The strongest presumptive evidence, however, in farour of anser ferus being the founder of the family is furnished by a fact mentioned by Mr. Yarrell. A pinioned wild gander of this kind, which had never associated with either bean goose or white fronted goose-although both were kept in the same piece of water with him at the gardens of the Zoological Society of London-was in 1841 introduced to a female of the domestic goose, which was selected for the cxperiment from the circumstance of her plumage exhibiting the distinctive marks of the true grey lag. The two birds were kept together for a few days, and the result was a matrimonial alliance and a nest of eight eggs. The bean goose (anser segetum), again, is very similar in general aspect to the grey lag and to the white frouted; but may be at once distinguished from the former by the nail at the end of the beak being black instead of white, by the darker huc of the wings and 
the orange colour of the legs; while the absence of the white feathers at the base of the upper mandible and on the forehead, are alone sufficient to point out the difference between it and the latter species.

There is another wild goose which has only of late years been added to the British fauna, viz. the pink footed (anser phonicopus). It closely resembles the bean goose in form and plumage, but may be easily recognised by its smaller size, and the pink or rose colour of the legs. Mr. Bartlett first pointed out these distinctions from an example which came into his possession in 1839. Mr. Yarrell records the occurrence of one at Holkham in 1S41, which was shot by Lord Coke-the present Earl of Leicester-out of a flock of about twenty ; and it would appear, from the following extract of a letter which I received from a friend who was staying on a visit at Holkham in $18 \%$, that there is something peculiarly attractive to this bird in the well preserved fens of that celcbrated estate. "Lord Leicester" tells me that some time ago lie shot a wild goose with pink legs, which Mr. Yarrell considered a new species. It is singular that since that time he has met with more of them than of any other sort. He showed me five which he had just killed." 
The bernicle (anser leucopsis) and the brent goose (anser brenta) are both smaller than any of those before named, and although differing considerably from each other in plumage, form and proportions, they yet present so many points of resemblance as to entitle them, in the opinion of some authors, to be included in the same genus (bernicla). They are both met with during severe weather in large flocks on the shores of the British islands, but the brent goose is more widely distributed, being at onee the most common, and the best flavoured bird of the whole family. In the winter of 1838-39 great numbers were killed on the coasts of the southern maritime counties. I saw many flocks, and shot several birds myself at Pagham Harbour, in Sussex, as well as many rarer anatide; but I did not meet with a single bernicle during the whole of that severe season. This last indeed is of more frequent occurrence on the westeru than on the eastern or southern shores of Great Britain; and is still more numerons in Ireland, where I have secn larger flocks of them than of any other kind of wild goose. Although a hearier bird, it is in my opinion far inferior to the brent gonse in a culinary point of view.

The shieldrake, or shelldrake (tadorna culpanser), one of the most beautiful of our cinatidre, 
is seldom met with in the interior of the country, even on the largest lakes and rivers, except in a half domesticated state. It breeds in the rabbit warrens on the sandy shores of the coast, and is generally considered a wary bird and very difficult of approach-so much so that in Orkney and Shetland it has acquired the provincial name of 'Sly goose.' When young, however, it would appear to be susceptible of domestication. A friend of mine told me that when at Sandringham in Norfolk-the property of the late J. Motteux, Esq. - he saw an entire family of young shieldrakes emerge from a rabbit hole in which they had been bred, when summoned by the whistle of the gamekeeper, partake greedily of the food that was thrown to them, and retire into the same retreat when their repast was finished. Although the strong and fishy taste of the flesh of this bird renders it almost unfit for the table, yct the striking arrangement of the black, white and chestnut colours of its plumage, with its bright red beak and legs, render it a great favourite on ornamental lakes and ponds in many parks and pleasure grounds. In such situations, even when pinioned, it has occasionally been known to breed; but the young birds, however carefully protected from the poacher and their feathered and fourfooted enemies, too frequently fall vic- 
tims to that fresh-water tyrant, the pike. A party of shieldrakes were kept for many years on a trout stream in Sussex, until in process of time the pike worked their way up from the deeper parts of the river, and soon afterwards the ducklings began gradually to disappear from the surface, until at last not a single young bird was left. The old ones then wandered down the stream, and their subsequent fate was unknown.

Although generally classed with the ducks, the shieldrake would appear in some respects to connect that portion of the anatida with the geese. Like the latter it is of considerable size, and there is little or no difference in the plumage of the male and female.

Many kinds of wild ducks and geese, which have of late years been admitted into the catalogue of British birds, can only be regarded as very rare or accidental visitors. Others, again, whose usual habitat is in the remote regions of Asia, Africa, or America, haring been occasionally shot or captured in different parts of England, the circumstance is frequently noised abroad - a paragrapli recording the occurrence appears in the local papers: the possessor of the fancied prize pens a highly colomred and plausible notice to the editor of some metropolitan journal : all attendant cireumstances that might militate against 
the preconecived notion of its being a genuine visitor are too often studiously concealed or slurred orer. The probable and frequently unmistakeable signs of semi-domestication, afforded by the state of the plumage, are not observed, or if observed are not alluded to; and in this way it cannot be doubted that many foreign birds may ultimately creep into the British fauna, unless a watchful but pardonable jealousy be exercised by the naturalist.

It is well known that on several lakes, ponds, Sc., great numbers of Oriental and other watesfowl, which have been imported from abroad, now exist. Most of these have been pinioned and are unable to fly. Others, on whom the operation has been inefficiently performed, occasionally make their eseape. But as many of these détenus breed freely on the islands, and among the sedgy banks of these ponds, there is nothing to restrain the second generation from leaving the spot, and migrating to some other part of Great Britain; where, if eaptured or killed, the poor foundling is announeed as a visitor of distinction, to be heneforth included in our catalogues. The following advertisement, copied verbatim from 'The 'Times,' refers to a well known establishment in London, where hundreds. of foreign, as well as really Britisl geese and 
ducks are annually procured for the waters of our English parks. "Ornamental water fowl, consisting of black and white swans; Egyptian, Canada, China, bernicle, brent, and laughing geese, shieldrakes, pintail, wigeon, summer and winter teal ; gadwall, Labrador, shovellers, golden eyed and dun divers; Carolina ducks, \&c. \&c., domesticated and pinioned." Some of our private museums, too, are loaded with continental specimens of anatide, which are fondly imagined by their possessors to be 'British killed birds,' because they were purchased in London 'in the flesh:' but their right to that title is frequently apocryphal. It is well known that the metropolitan markets are regularly supplied with water fowl from France and Holland; and the eril is likely to increase every day, under the influence of railways and accelerated stcam communication. There can be little doubt that erc long the London gourmand may receive the canvas-backed duck from America, and probably in better condition than many of the capercaillie and ptarmigan that now find their way to the poulterers from the distant forests of Norway and Sweden.

The ducks best known to the sportsman and the shooter on the coast are, The common wild duck (anas boschas), the teal (anas crecca), the 
wigeon (anas penelope), the pintail duck (anas acuta), the pochard or dun bird (fuligula ferina), the scaup duck (fuligula marila), the tufted duck (fuligula cristuta), and the golden eye (clangula vulgaris). The four first of these belong to the more typical division of the ducks: their habits are to a certain degree terrestrial; they are more partial to fresh than to salt water; their food, besides aquatic insects and worms, is frequently of a regetable nature, and usually obtained near the surface-beneath which they seldom dive, except when wounded or pursued-while their powers of flight are very great. In conformity with these habits is their general structure; the legs are smaller, more rounded-or less compressed laterally-than among the marine ducks, and placed nearer the centre of the body; their necks and rrings are longer; the keel of the breast bone is deeper; while the stomach approaches more nearly to the nature of a gizzard, as in granivorous birds. The other four species belong to the oceanic division. They are more decidedly aquatic, and prefer the sea to either lakes or rivers, cxcept when driven in by severity of weather. Their food consists almost entirely of fish and marine insects, and the stomach accordingly is softer and thinner than with their herbivorous congeners. Their legs are short, com- 
pressed, and placed far behind; the feet and webs large; and the hind toe furnished with a lobe. The neck is comparatively short, as are the wings also; and the keel of the sternum is shallow. They are exceedingly expert divers, and obtain their food at a great depth below the surface of the water. Of these, the pochard, or dun bird, is perhaps the best known and the most in esteem as an article of luxury for the table; indeed it is nearly allied to the celebrated American species, the canvas backed duck, which has long been in such repute with Transatlantic epicures.

Pochards are more frequently found in decoys with mallard, teal and wigeon, than any other of the marine ducks; but from their greater shyness, and propensity to dive back through the mouth of the pipe at the slightest alarm, they not only effect their own escape, but frequently disturb the other birds already congregated there, and are consequently regarded as unwelcome visitors by the fowler.

The decoys of Lincolnshire have for ages been celebrated, and several establishments still exist in that county; although from the recent drainage of the fens, they have been in a great measure shom of their honours; and in process of timelike so much that is still highly prized by the 
sportsman and the lover of the picturesque-must yield to the irresistible pressure of agricultural improrement. 'The common wild duck, the wigeon, and the tcal furnish the main supply of the wildfowl captured in this way. Some notion of the extraordinary productiveness of the Lincolnshire decoys may be formed from a fact recorded by Pemnant, that in one season 31,200 ducks were sent by ten of them to the London market.

Such of my readers as desire to understand the exact nature of a decoy, and the complicated details of its structure and management, will find an interesting and elaborate account in the Rer. R. Lubbock's 'Fauna of Norfolk,' clucidated by several explanatory sketches and illustrations; without which, indeed, the subject cannot be thoroughly comprehended.

To those who are anxious to be initiated into all the mysteries of wild fowl shooting on the coast, Colonel Hawker's 'Instructions' afford a mine of information. For my own part, although I have in former days occasionally shivered behind a stanchion gun for the best part of a long frosty night, in the shallow watcrs of a creek, and passed many an hour on the borders of a lake near the mouth of a river, awaiting the retum, at early dawn, of wild ducks and wigeon from their feed- 
ing places among the bogs; and have, on such occasions, met with as fair a share of success and disappointment as usually falls to the lot of any but a professional wild forl shooter; yet I must confess that my predilections are rather with the forling-piece or the rifle than with the heary artillery of the craft; and that I have felt more real pleasure in a day's snipe shooting, which was varied by an occasional right and left at a duck or mallard, or an unexpected shot at a teal or wigeon as they sprang from the sedgy borders of some sequestered pool; or in stalking a flock of wild geese in the middle of a great Irish bog-though perhaps bagging but one of the party after an hour's patient manœurringthan in the greatest success I ever experienced after waiting for the arrival or passage of water fowl, or in the best family shot I erer made from a gun-boat.

The principal destruction of wild fowl in the British islands takes place on the coast during severe winters, and although when they have returned to their summer quarters among the innumerable lakes of the Arctic regions, far from the busy haunts of men, it might be supposed that they and their young would be secure from the attacks of any very formidable encmies, yet it is not improbable that a great portion of the brooks 
are there destroyed by predatory fish, soon after they have left the egg. We know that the Seandinavian waters abound with pike of immense size, and if we may judge of the propensities and powers of these monsters from what we see in our own country, the destruction of aquatic birds during the breeding season must be very great. Vast numbers of the young of the common wild duck are annually devoured on the ponds or artificial lakes in parks or pleasure grounds where this voracious fish abounds; or even where a few of the specics have attained a considerable size, and the quantity of 'feed,' in the shape of roach and dace, has been much reduced. In this way about two hundred ducklings disappeared from the large pond in Petworth Park this summer, 1850. Here there was 110 lack of small fish; but to the truculent propensities of certain fresh water leviathans who are known to dwell beneath, and who are proof against the seductive stratagens of the most experienced troller; or perhaps to the circumstance of their being already glutted with an entrée of fish, and willing to vary their dietary with a sccond course of wild fowl, may be attributed the murder of the little innocents.

Lord $\mathrm{G}^{* * * *}$, an observer of nature and an accomplished angler, was, I believe, the first 
person to arail himself of this epicurean taste in the pike, by constructing artificial birds-rather than flies-varying from the size of a wren to that of a young duck, and composed of all manner of gaudy feathers, silk, and tinsel, to attract the attention of the monster and lure him to the deadly hook, when his appetite might be capricious or the water muddier than usual. When this bait is worked a little under the surface - just as they play a salmon fly on the Shannon - its movements appear exceedingly like those of a young water-fowl when diving. This struck me particularly one day, when endeavouring to rescue a half-grown moor-hen from my retriever, who had pursued it through a thick bed of flags and sedges into a narrow and deep but transparent brook. The dog was close behind, and had already caught a glimpse of the poor bird, who, funding it impossible to escape down-stream without passing under the legs of its enemy, had no alternative but to dive against the current, although it made little or no progress; and the manourre would doubtless have failed, if I had not succeeded at that moment in withdrawing the dog's attention and calling him to heel; but I could not help observing that the strugghes of the little moor-hen to contimue under water, and its ineffectual attempts 
at progression-in which the wings were chiefly employed and the legs played a comparatively unimportant part - were admirably imitated by the movements imparted to Lord $\mathrm{G}^{*}$ ***'s fly by the hand of a practised performer. I have since had several opportunities of testing its eflicacy, and although I am satisfied that a greater number of jack may be killed with the ordinary bait-gudgeon, roach, dace, \&c._yet I have invariably found that the 'bird-fly' took the largest pike; to say nothing of the superior style of the sport, and of its tendency to elevate the comparatively tame pastime of trolling a few degrees nearer to the noble art of salmon fishing. 


\section{CHAPTER VII. \\ "And mony a weary cast I made \\ To cuittle the muirfowl's tail."}

WALTER ScotT.

Red Grouse-Limits of its Range-Natural Enemies, winged and four-footed - The Badger unjustly proseribed Unsuceessful Attempts to re-establish the Red Grouse in the South of England - Ptarmigan - Its Haunts and Habits - British Game Birds - Order in which they arrive at Maturity-Annual Importation of PtarmiganHighland Moors-Mayo Mountains-Shooting Expedition-Lodge-Backward Season-Operations deferredWild Seenery-Youthful Ardour and Veteran Coolness - Variety of Sport.

Tre geographical distribution of the red grouse being strictly limited to these islands, it is more exclusively a Britislı bird than any kind of feathered game of which we can boast, all the others being dispersed over different parts of the continent of Europe. But as this exists in Ireland, Wales, and in the North of England, as well as in Scotland, its specific appellation Scoticus is hardly correct; and it has been suggested, with reason, that Britannicus would be a more appropriate epithet. Being essentially a 
denizen of the wild heathery mountain and moor, it recedes invariably before the face of civilization, and may be said, at the present day, to be extinct in the Soutl of England, very scarce in the central portion-Staffordshire and Derbyshire being probably its southern limit - and although still found in tolerable numbers on the moors of Yorkshire, jet it is of less frequent occurrence there than it was a few years ago, when Lord Strathmore's keeper shot forty-three brace before two o'clock in the afternoon, on the 12th of August. The great stronghold of the species is of course the Highlands of Scotland, where its preservation is carried to such an extent, and the rights of shooting let at such high rents, that in spite of the anuual slaughter during the first three weeks of the season-far surpassing in this respect even the battue of the southron - there appears to be no immediate prospect of its extermination or even material reduction, although, speaking as a naturalist rather than a sportsman, it cannot but be a matter of regret that the excessive protection of the grouse involves the indiscriminate slaughter of so many interesting birds and quadrupeds now becoming exceedingly rare amongst us.**

* Subjoinerl is a list of "vermin' (!) destroyed on the celebrated Highlanl property of Glengary, between Whitsunday 
After the month of August grouse are better able to take care of themselves, and, although comparatively safe from the legalized shooter during the winter, great quantities then fall victims to the Highland poacher, especially when snow is on the ground, as they pack together in considerable numbers, and expose themselves on any turf-stack, wall, or bank that happens to rise abore the surface of the moor. They are also snared, and occasionally netted; although, from a habit in these birds of scattering

1837 and Whitsunday 1810 , previous to the purehase of the estate by Lord Wrard. The slaughter was carried into effect by numerous keepers, who reecived not only liberal wages but extra rewards, varying from $3 l$. to $5 l$, according to their success in the work of extermination.

The ornithologist will be a little puzzled by the titles giren to some of the Raptores, but the names and epithets applied to the greater number of them are nevertheless unusually clear and appropriate, and will leave no doubt on his mind as to the identity of mauy oî the rarer rictims. I will only add, that I have receired this 'black list' from the hands of the gentleman himself, who was the lessee of the shooting at the time, and by whose orders the exceution took place. Althongl a good sportsman and an execllent shot, it must be adnitted that his zeal as a preserver of game far ontstripped his sympathies with other animals.

11 Foxes.

198 Wild-ents.

246 Martin-cats.

106 Pole-cats.
301 Stoats and weascls.

fii Badgers.

th Otters.

is llouse-cats, groing will. 
at the approach of the fowler, this last mocle of capture is less profitable than might be imagined, and it is certain that various stratagens are then in rogue-when, by the way, the keepers and watehers are gencrally dismissed, instead of being doubled as they ought to be--for the London market is regularly supplied, up to the middle of March, with birds which exhibit no signs of having perished from a gunshot wound, but have evidently been procured by some of the numerous contrivances of modern poaching.

27 White-tailed sea eagles.

15 Golden eagles.

18 Osprey, or fishing eagles.

98 Blue bawks, or peregrine falcons.

275 Kites, commonly ealled salmon-tailed gledes.

5 Marsh harriers, or yellowlegered hawks.

63 Gushawks.

7 Orange-legged faleons.

11 Hobby hawks.

2ヶ.j Common buzzards.

3i1 Rough-legred buzzards.

3 Honey buzzards.
462 Kestrels, or red hawks. is Merlin hawks.

9 Ash-colomed hawks, or long blue-tailed ditto.

83 Hen-luarriers, or ringtailed hawks.

$6 \mathrm{Jer}$-falcon, toc-feathered hawks (?)

1431 Hooded, or carrion erows.

475 Ravens.

3.5 Horned owls.

71 Common fern owls.*

3 Golrlen owls. $†$

8 Magpies.

* This, I imagine, was the slıort-cared owl (otus brachiyotos.) Surely not the insectivorous nightjar! A.E.K.

+ Probably the white, or barn owl (strix flummeu). 
Among the natural enemies of the red grouse, the hooded crow (corvus cornix) holds a prominent place. His depredations are committed during the breeding season, and are of so wholesale and destructive a character as to demand the especial attention of the intelligent keeper. The peregrine falcon, it must be admitted, is an occasional offender, but the number of full-grown birds, on whom alone he condescends to prey, is as nothing compared with the amount of silent mischief perpetrated by the hooded crow. The ashcoloured harrier, or moor buzzard (circus ceruginosus) in former days, before the species had been almost swept from the face of the land, might now and then have been convicted of pouncing upon a lialf-fledged poult, as he traversed the heath in quest of food during his evening flight. The golden eagle (aquila chrysaëtos), when larger prey is unattainable, will occasionally, but rarely, stoop to truss so small a quarry as a grouse; and the sea, or white-tailed eagle (halicëtus albicilla) is even less frequently an offender, while the destruction of these noble birds lias caused an unnatural increase in the number of mountain hares (lepus variabilis), a result, in the opjinion

* I am informed on good authority that, during a single day in September, 184:), four guns killed, on a mountain near Loch Ranoch, 574 hares. 
of Mr. St. John, to be deprecated by every sportsman; as from the extraordinary fecundity of these animals they become so numerous as to be "a perfect plague to grouse dogs." The kestrel, the hobby and the merlin - to say nothing of the harmless habits of the first-named-are of themselves too diminutive to deserve the hostility of the Fighland keeper. The white owl (strix flammea) and the wood or tawny owl (symium aluco) are comparatively rare in Scotland, and fortunately for themselves, play an inferior part in the drama; while those autumnal visitors, the short-eared owl (otus bracliyotos) and the rough-legged buzzard (buteo lagopus), who leave this island in the spring, and are therefore absentees during the breeding season, are shot and trapped, during their brief sojourn, without mercy; although the latter alone deserves to be classed, and even then with reservation, among the natural enemies of the grouse.

With a greater show of justice, the fox, the cat, and the various members of the weasel family, are proscribed as outlaws; yet the lover of the British fauna cannot fail to regret the rapid decrease which the excessive preservation of the grouse is entailing among several of our native quadrupeds. The pine marten and the wild cat have already disappeared from the south, 
and the same persecution that has banished them from thence, must eventually extirpate them from their northern fastnesses. These animals, however, are notoriously hostile to game of all kinds, and even the partial toleration of a limited number is more than can be expected: but what can be said in defence of the 'war to the knife' waged even at the present moment against the poor badger? The agriculturist, whose corn-fields have been damaged by its inroads - and there are few places at the present day where they exist in sufficient numbers to occasion serious mischief of this kind-or the fox-hunter, whose temper has been repeatedly tried by the ineffectual efforts of his huntsman to dislodge an exhausted reynard from the deepest recesses of the badger's hibernaculum, can show at least a plausible 'casus belli;' but the game-preserver has no such excuse. This interesting animal, the last representative of the urside (bears) in the British islands, rarely - so rarely, indeed, that an offence would prove an exception to the rule - interferes with his concerus. A casual observer, it is true, on examining his teeth, would suppose that he was eminently camivorous, but such is not the case. The long fangs, which in most predatory quadrupeds are used to tear the museles of their recently killed prey, are 
('mployed by the badger in wrenching out the tough, interwoven and deeply-imberded roots of the trees which impede the excavation of his den; a process which is further facilitated by the immense muscular power of lis jaws, and their peculiar structure and articulation; and, although he occasionally derours some of the smaller quadrupeds, yet his food is principally derived from the regetable and insect worlds. Chestnuts, roots of all kinds, blackberries, beechmast, and all mamner of beetles, with the larvæ of wasps and wild bees, furnish his ordinary supplies; while eren frogs and snakes contribute to vary his dietary during the summer and autumn. It is therefore difficult to palliate the senseless persecution which, in these islands, has already doomed the species to a gradual but certain destruction.

While black-game seem to require a combination of wood and swamp, a considerable extent of open mountain or heathery moor is necessary for the red grouse; for, like the Indian of kindred hue, he recedes before the plough of the white man; nor have the many laudable attempts to re-establish the species in districts from which it had once disappeared been attended with success. The experiment has been tried in Devonshire, in Dorset, in Sussex and 
in Surrey, with a similar result. The late Duke of Gloucester, in 1829, turned out eight brace and a-half on Bagshot Heath, These birds had been previously kept in confinement for three years, and it was therefore hoped that the inducement to wander beyond the preciucts of their new quarters would not be so strong as if they had been but recently imported from their native moors. From the day, however, on which they were turned down, the keepers never met with one; but about two years afterwards, in the month of July, four-two old and two young - were seen on Cobham Heath, a larger and wilder tract several miles distant. These were subsequently shot as grey hens, of which a few are still occasionally seen in that district.

The ptarmigan (lagopus mutus) is now to be found only on the loftiest summits of the higher ranges of mountains in the central and northern parts of Scotland, and on some of the western islands. It was said to have existed in Wales, but half a century at least must have elapsed since its occurrence in that Principality. Its haunts are among the snow-covered peaks and bare rocks, far above the heathery regions inhabiter by its congener, the red grouse; and, from the inaccessible nature of these retreats, the species is not likely, at least for mumy years, to be exter- 
minated by the hand of the sportsman. Nature has, moreover, provided a safeguard in the tints of its plumage; presenting in summer a mixture of black, yellow, white, and grey, exactly resembling the colours of the mossy lichencovercd rocks and stones where it lies concealed; and which, becoming gradually whiter as the season advances, at last nearly assimilates itself to the snows of winter; although our Highland birds seldom or never exhibit the unadulterated purity that distinguishes those Lapland and Norwegian specimens with which the London markets are so plentifully supplied every year. The young ptarmigans, too, evince a wonderful instinct, during the summer, even after they have attained the power of flight, in concealing themselves rapidly between the stones, and remaining perfectly motionless, close to the very feet of the adventurous tourist, who in vain endeavours to discover them, so exactly does their colour resemble that of every surrounding object; and the task is rendered still more puzzling by the ready wiles of the mother-bird, who, fluttering and struggling in well simulated distress, has distracted his attention for a moment from her little ones.

There are not many sportsmen who derote much time to the exclusive pursuit of the ptar- 
migan; for, though naturally unsuspicious and easy of approach, yet the toil to be endured and difficulties to be orercome before these Alpine heights can be reached, are much increased by the impossibility of following the birds from one rocky corry to another, separated perhaps by a giddy precipice, orer the edge of which they have suddenly disappeared from the view of the wearied shooter. A circuit of considerable extent must frequently be taken, and many a steep acclivity or dangerous descent encountered, before they can be found again; while there is small chance of relieving this tedious interval by a stray shot at any other bird or quadruped, except the grey hare, who seems to share with the ptarmigan the occupation of these inhospitable regions, while they both undergo a nearly analogous change in their seasonal rariations of fur and feather.

It is certainly a remarkable circumstance in the natural history of our game birds, and a striking instance of the merciful dispensations of Providence, that those which inhabit the most northern and inclement quarters are the earliest in season; or, in other words, arrive first at full growth, and are therefore soonest enabled to brave the rigours of the coming winter. Thus, the joung ptarmigan is able to $\mathrm{fly}$ before the red 
grouse poult can flutter above the heather. The latter, again, when strong on the wing, has fallen in thousands before the gun of the sportsman, ere its report can be legally heard among the birchen glens and the lower valleys where the black-cock loves to dwell; while he, in his turn, now come to maturity, may be bagged nearly a fortnight before the partridge; who has been peppered throughout the length and breadth of the land for a whole month, before the gorgeous pheasant-who as an exotic might have been suspected of precocity-is considered ripe for slaughter.

Most persons have noticed the vast numbers of ptarmigan which appear in the shops of the London dealers, and in the stalls of the principal metropolitan markets, during the latter part of winter and the carly months of spring, even as late occasionally as the beginning of May; but comparatively few are aware that scarcely one of these birds has been killed on the Scottish mountains. They are imported from Lapland and Norway: the greater number from the western ports of the latter country. Mr. Yarrell says, that in the year 1839 one dealer alone shipped six thousand for London, two thousand for Hull, and two thousand for Liverpool ; and early in March 1S10, a salesman in Leadenhall 
Market received fifteen thousand ptarmigan that had been consigned to him. Sir A. de Capell Brooke calculated that sixty thousand had been killed during one winter in a single parish in Lapland; and Mr. Lloyd says that a dealer in Norway will dispose of fifty thousand in a season. The profit to the importer must be great, as a single ptarmigan, which is seldom disposed of in London for less than two shillings or two and sixpence, is sold in the market at Drammen for the trifling sum of fourpence. Strange as it may appear, all these birds are taken in separate horse-hair nooses during the winter; and so brisk a traffic is carried on by the peasantry at that season, that one of them, we are told, will set from five hundred to a thousand of these snares.

There is a second species of ptarmigan in Norway (lagopus saliceti, or subalpina of Nilsson). It is larger, and found in lower and less mountainous districts, than lagopus alpina of the latter author, which is identical with the Scottish bird (lagopus mutus).

But to return to the red grouse. Thanks to railways and the rapidity of steam communication between London and Inverness, the acquisition of a first-rate moor is now only a question of money; and the opulent citizen who but 
yesterday was buried in the pages of his ledger, amid the smoke of Threadneedle Strect, may find himself to-morrow regularly located in his Highland lodge, bracing his relaxed nerves with the mountain breeze, or despatching baskets full of grouse for the hospitable tables of his less fortunate friends in 'the city.' It may be observed, however, that bitter disappointment not unfrequently follows in the track even of the wealthy Saxon. The right of sporting may comprise many thousand acres, yet not contain as many score of grouse, which perhaps hare been shot down to the very verge of extinction by the former tenant, who has probably availed himself of his right to reap the roward of a long period of care and protection during the last season of his occupation. Such a result however may generally be avoided by a previous inquiry on the spot, while to obtain a 'well stocked moor' in the modern acceptation of the term, it is advisable to secure the tenancy for several successive seasons. But with the nature of Highland shooting alnost every young sportsman is familiar, if not by actual experience, still by general report. In the sister island, however, the case is somewhat different. The system of letting the manors has not yet been introduced. The admixture of woodcocks, snipe, plover, and 
wild-ducks frequently adds a peculiar charm to the pursuit; and as in my humble opinion the character of a day's shooting depends rather upon the variety of the spoil than upon the numbers of the slain, I will ask my reacler to accompany me for half an hour to the scenes of my boyhood in the West of Ireland, where, in bygone and better days, I made my first acquaintance with the "hen of the heatho"*

Many years have elapsed since, with a middleaged relative, a cool and experienced yet an ardent sportsman, I undertook an expedition to ' the mountains;' a wild tract of considerable extent in the north-western portion of the island, which had been carefully preserved under the management of an intelligent Scotch keeper, who, by the establishment of local watchers and a judicious reduction of predatory animals - among' which the hooded or 'scaul crow' occupied his chief attention-had succeeded in getting up a fair head of grouse and hares, and at the same time ensuring to the different species of wading and swimming birds, which haunted the streams and lakes of this remote district, that quictude and repose which are so important to the success of the wild fowl shooter.

* 'Cark na fre,' or 'hen of the heath,' the nane by' which the red grouse is known in the remote parts of Connaught. 
We had risited the confines of these mountains about two months before, at the beginning of the grouse-shooting season, but the weather was sadly against us. 'Taking up our quarters on that occasion at the house of an intelligent and enterprising tenant-one of the better class of farmers, who, as the first pioneer of agrieulture in this spot, had boldly undertaken to reclaim an entire valley from its primæval state-we sallied forth on the morning of the 20th of August, with the intention of beating our way across the heart of the mountains in the direction of the lodge; which, although apparently a rucle and umpretending cottage, had been lately erected with considerable difficulty, in consequence of its almost inaccessible situation in a remote gorge of the mountains and at a great distance from a road of any kind: most of the materials indeed had been procured on the spot; stones from the neighbouring ravine, heather from the surrounding hills, and fir-wood disinterred from the bog, and conveyed to its destination on the backs of native ponies, contributed in their turn towards its construction.

The weather was most unpropitious. A close drizzling rain had set in the evening before, and even the nearest mountains were cnveloped in an Irish mist, which, for persevering 
and penetrating qualities, may at least claim to be put on a par with its Scottish namesake. However we took the field in good time, and after ranging the moors for some hours, rather for the purpose of exercising two brace of promising young setters than with any expectation of sport, and after being thoroughly drenched to the skin, we returned to the farmhouse with five brace of grouse, wliose halfdeveloped plumage and small proportions convinced us of the backwardness of the season. This consideration, indeed, coupled with the continuance of bad weather on the following day, induced us to postpone our grouse-shooting until a later period, when the first flight of woodcocks should have arrived. These make their appearance about the beginning of November, and scatter themselves over the mountains, where they may be found in consiclerable numbers during that month; but as the winter advances they gradually retire from the hills, and take up their quarters in the natural woods that clothe the lower slopes of the ridges near the great lakes; or become concentrated in the covers of the interior of the island, especially during hard weather, when additional reinforcements continually drop in from England, Trales and Scotland. The grand point therefore is to 
take them as soon as possible after their first arrival among the mountains. The best shooting I ever enjoyed was of this description, especially in the neighbourhood of some small loughs fed by dark boggy streams from the higher grounds, where, when the dogs pointed, I could not tell whether I was about to flush a grouse, a hare, a woodcock, or a wild-duck from the heather.

Our forbearance seemed likely to be rewarded on the present occasion. The latter part of October laad been particularly fine, and for the past week the clear nights, obscured but occasionally by a few light clouds as they sailed slowly across the moon from the north-east, promised a grand immigration of cocks. Relays of dogs, a goodly store of ammunition, and a supply of creature comforts for a week, had been despatched on the previous day; and it was our intention to put up for the first night at the farm-house before mentioned, so as on the following day to carry out our original plan -though under better auspices-of shooting our way across the hills to our head-quarters at the lodge.

For nearly eight miles our route was practicable for an Irish car. We passed at first through a partially cultivated country, gradually ascending higher and higher as we neared the 
dark mountains, and every now and then obtaining a view of the open sea on our right, or catching a glimpse of a tremendous precipice in the distance; until, on surmounting an ascent of more than usual tediousness and length, a magnificent scene was suddenly spread before us. Beneath lay a valley, through the centre of which dashed a wild stream, from whose well known waters, when a boy, I have many a time filled my basket with the small pinkfleshed mountain trout. Further on to the right the hills on either side gradually approached each other, forming a dark ravine, through which the little river hurried in many a foaming cascade on its way to the sea, which stretched away as far as the eye could reach, from the Stags of Broadhaven to Killala Bay. A lofty isolated rock, the abode of myriads of sea birds during the breeding season, stood at a short distance from the precipitous coast, whence it seemed to have been detached by some convulsion of nature, or by the continuous action of the eternal waves of the Atlantic. Far in the north-east the blue outline of the Donegal cliffs was visible on the horizon, while over this vast expanse of ocean not a sail was to be descried; but at least a mile from the shore, although apparently much nearer, a little group 
of black fishing yawls, manned by a few rowers, paddled about like a cluster of water beetles, all engaged in setting their 'spillets,' or drawing in their well loaded lines; as, prompted by the impulse of immediate want, they were lazily dabbling in those prolific waters, the finny treasures of which, like another California, are doubtless reserved for a future period and a more energetic people.

Before us, and on our left, rose mountain over mountain; no longer grey and indistinct, but of a rich brown colour, still varied here and there, even at this late period of the season, with the purple blossoms of the heather. On the sides of some of the nearer hills a long winding strip of the brightest verdure might be seen, marking the course of some little stream, which drained the ground near its banks on either side, and pursued its tortuous and broken way to become a tributary to the river in the valley; and here a few stunted rough-coated cattle were dotted along its margin. All else, as far as the sight could penetrate into the interior, seemed to be mountain and bog, without the trace of a human habitation, and where apparently nothing but grouse and snipes could manage to procure a subsistence.

Another hour brought us to our former quar- 
ters at the farm-house. Here the road terminated, and all communication with the lodge was carried on by means of natives from the nearest village, whose limbs, unshackled by shoe or stocking, displayed an enviable activity in traversing the rough broken grounds; and whose light-hearted merriment and good temper contributed not a little to the pleasures of the expedition. A few of these only were selected as markers, and ordered to be in their respective positions among the hills before day-break on the following morning; while the rest were despatched the same evening with sundry articles of heavy baggage to the lodge, and instructed to meet us on the morrow, with a relay of dogs, near the borders of a little lough, which we expected to reach early in the afternoon.

We started with a good omen. Our breakfast was hardly despatched and our guns in our hands before one of the watchers, who had been in position since the earliest dawn, came running down with the welcome intelligence that he had marked two fine packs of grouse in a neighbouring valley, and that, while hurrying with the news at his best speed, he had flushed several woodcocks along the brow of the mountain. WV were soon at work. We had four good setters with us, but two of them were led in reserve 
for the present, and the remaining brace now scoured the moor in all directions. For nearly half a mile our beat lay across a boggy plain. Here we sprung several snipes, which in my youthful ardour I would gladly have shot, and even felt strongly inclined to rate the well broken dogs, as they put them up one after another with as little compunetion as if they had been larks: but I was restrained by the conduct of my more phlegmatic relative, who assured me that a snipepointing $\log$ was the worst companion that a grouse shooter could be eursed with. Further discussion on this subject was abruptly closed by a signal from the keeper. Bob and Ranger were down. The latter had found game, but being of a deep red colour it was some time before I could distinguish his head above the heather, while his black and white coadjutor was distinctly visible, although, like the former, he always lay down to his birds. Presently a fine pack of grouse rose within a fair distance for our four barrels. How different from the puny poults of August! These were really grouse. Young birds, it is true, and unable to bear the weight of their well conditioned bodies when suspended by the lower mandible without that portion of the beak giving way; but in perfect plumage and full growth. We had now arrived at the foot of the mountain, 
one side of which flanked the valley where the two packs had been marked down in the morning; but we took a wide range over the higher brow, and presently Bob was down again among the the heather at some distance above us. This time it was a woodcock. Several more did we kill before we descended to the hollow, where we found the two packs at home, and passed the best part of an hour in marking down, and bagging in detail, the stragglers which had been scattered at the first discharge. For the next two hours our sport was of a varied character. Half a dozen more woodcocks, about the same number of grouse, and two or three brace of hares, were stuffed into the panniers which our attendants carried with marvellous ease, like turf baskets, on their shoulders. At last we came to the summit of a hill commanding a view over a bare plain of most unpromising aspect. This, howerer, must be crossed, for just beyond it we could descry the little lake, set as it were in a framework of green sedgy banks, where we expected luncheon and fresh dogs. Before traversing this marsh we took up the setters, and had no hesitation then about shooting two or three couple of snipes that sprang at our feet, and in pouring a volley into a small flock of golden plover, as they dashed heedlessly by 
within an imprudent distance. But the best sport was after luncheon. With the assistance of a water-spaniel, we flushed and killed several ducks and teal from the swampy borders of the lough, and recovered most of what we killed. Then, with fresh dogs, we again scoured the brows and mountains in quest of grouse and woodcocks, of both of which we found a sufficient sprinkling to satisfy our most sanguine expectations; and, although once or twice, when nearly knocked up, I was decoyed by the plausible point of a young dog far into the rear, and found nothing for my pains but a diminutive jack snipe, yet I never more fully enjoyed a day's shooting, or experienced in a higher degree the associated charms of wild sport and romantic scenery. 


\section{CHAPTER VIII.}

\section{"Ase, springes to catch woodcocks." - SuAKSPEArE.}

The Woodeock-Modes of Capture-Net and Gin-Woodcock trapped - Attempts to Rear it in Confinement Insatiable Appetite of the 'Bird of Suction' - Rapid Digestion - Crepuscular Habits - High-road Gunners Netting-Snares, Aneient and Modern-The Old Poacher and lis Springe.

Although it is principally to the inefficiency of the game laws, to the increasing taste for shooting which pervades all classes of scciety, and to the facilities afforded now-a-days for the acquisition of a good fowling-piece, that the scarcity of partridges and pheasants in many counties may be attributed; yet the woodeock not being strictly included in the same category, and a certificate not being necessary for its legal destruction, it is still more persecuted by the gunner and less sought after by the wirer and trapper than birds of the gallinaccous order. Being fortunately a migrant-with some exceptionsfrom the boundless forests of the North, a fair 
THE WOODCOCK-MODES OF CAPTURE. 199

supply arrives annually on the coasts of the British islands, and thus the slaughter which would otherwise tend to the rapid diminution of the species is in a great measure compensated.

In olden time, when a ponderous matchlock or a tardy single-barrelled flint gun were the most efficient instruments the shooter could command, it was no easy matter for the legitimate sportsman to bag a couple of these birds when fairly flushed by his cockers from the coppice or brushwood, and to kill a woodcock flying was justly considered a triumph of the art. Various modes of capturing it were then in vogue, some of which are still practised in certain districts even at the present time, although with the exception perhaps of the net, they are gradually falling into disuse, or have been succeeded by the more elaborate improvements of modern poaching; while the fatal double, like the schoolmaster, is abroad, in whose presence the primaval weapons of our ancestors have long since 'paled their ineffectual fire,' and after the lapse of another gencration will probably be regarded as the clumsy contrivances of a semibarbarous ara.

The gin, or iron spring trap, was much used formerly to take woodcocks. We find the circumstance frequently alluded to in Shakspcare. The haunts of the birds having been ascertained, 
the trap was set in 'the run,' partially sunk in the soft mud and concealed with a few leaves. The simplicity and portability of the gin still render it a favourite with all neophyte poachers; and, except in a more delicate and refined style of workmanship, there seems to have been but little improvement of late years in its manufacture. I have seen a very ancient one, the construction of which was nearly similar to, and the principle identical with, the modern rat trap, which, under various trifling modifications, has, even in our own days, been contrived to capture every animal of moderate size, from a man to a mouse.

The partiality of the woodcock to certain feeding places which would appear not to possess any unusual attractions for him, and the pertinacity with which he regularly pursues the same path, are very remarkable. When quite a boy, I once availed myself of this habit to catch a woodcock, which I fondly imagined I could successfully rear in confinement. The scene was in a small dell of birch and alder. A common box trap, such as is used for taking rats and stoats or weasels alive, was the instrument that I thought most likely to suit my purpose. This I placed exactly in the middle of the run, where the tracks and perforations were most numerous, 
but without taking the precaution of screening it from observation. On risiting the spot riext morning I found that my first essay had been unsuccessful: and a short examination sufficed to show the cause, There were traces of at least one or two woodcocks close to the trap; but instead of attempting to pass through it, they had inclined a little out of the direct line, and, apparently without evincing any other symptom of alarm, had, after passing the obstacle, resumed their course through the swamp. I now placed a few boughs on both sides so as to prevent a recurrence of this mishap, but not without sundry misgivings that my rude fence might cause the birds to take flight, and perhaps scare them from their feeding places. My apprehensions, however, were groundless, for on the following morning I found a woodcock safely incarcerated, which, as a faithful chronicler of facts, I am bound to confess soon died under my fostering care; partly, perhaps, because it was an old bird, and obstinately refused to insert its bill into the most tempting dishes of soft mud with which I liberally supplied it-taken moreover from the very spot on which it had seemed to luxmiate in a state of nature-- but principally, I believe, from my ignorance of its proper food and the insatiableness of its appetite; for 
I was at that time impressed with the erroneous belief, shared by many even at the present day, that as 'a bird of suction' it required no substantial food for its maintenance: but 'experientia docet.' I afterwards succeeded in rearing a young woodcock by feeding him plentifully with earthworms - the species called brandlings, which abound in old heaps of compost, were the bestthese, when mixed with wet mould, he devoured greedily; and I found no small difficulty in furnishing him with a sufficient quantity, while I varied his diet occasionally with gentles, tadpoles, and the larvæ of aquatic insects. He became quite tame and reconciled to his place of captivity, which was an outhouse, the door of which had been removed and replaced by a fragment of an old fishing net. Like all pets, however, he met with an untimely fate. An inquisitive spaniel managed to creep under the net one afternoon, and although a specly rescue was attempted, it was too late; his career was cnded. Being in exccllent condition he was handed over to the cook, and a better bird never appeared upon a table. So rapid was his digestion, that the stomach was perfectly empty, and the other viscera, or ' trail,' contained only the peculiar cream-like matter usually found in the woodcock, while its flarour was positively irre- 
proachable, although he had breakfasted that very morning on nearly half a flower-pot full of worms.

The woodcock being a crepuscular and nocturnal bird, that is to say, his active life commencing in the evening and continuing throughout the night, the regular sportsman meets with him only when flushed reluctantly from those spots to which he retires for concealment during the open day. His organs of vision, like those of the owls, the nightjar, the great plover, and other birds that feed principally after sunset, are large and prominent, and admirably adapted for concentrating the partial and confused rays of twilight. At that hour he quits his shady retreats among the fir and holly plantations or the great woods, and flying along the open roads and alleys that lead to the adjoining meadows, swamps, moors, or lowlands, he passes the whole night in search of food. It is a remarkable fact that the impulse to take wing seems to pervade these birds at nearly the same moment, and during the protracted twilight of spring, great numbers fall victims to these pot-hunting gunners whom the unrestrained use of fire-arms is too apt to encourage among an idle and uncmployed population. 'The facilities for this sport (!) are great. No trespass is committed; no game certificate 
is necessary. A high road flanked by a large wood is usually the scene of operations; the birds fly within a few yards of the shooters, sailing down the alleys of the cover and crossing the road with a noiseless owl-like motion of the wings, as different as possible from the rapid dashing flight that characterizes them when flushed during the winter. They are, moreover, generally feeble and emaciated, and altogether unworthy of the attention of the sportsman or the epicure.*

At this season, and even cluring moonlight winter nights a very destructive mode of fowling is still practised in eertain parts of England, but more frequently in some of the TWestern counties and in Wales than elsewhere. Light nets with wide meshes are slung across the rides in the great covers, the ends being either supported on poles, or slightly attached to the upper branches of trees on both sides of the ride, or near a gateway over which woodcocks have been observed to pass.

* I am aware that, by a elause introdueed a few years ago into the game laws, this offence is supposed to be legally liable to punishment ; but practically the measure is generally found to be incfficient. A ease occurred lately within my own knowlerlge, where a party of these turnpike poachers, although eaptured 'in flagrante delicto', were aequitted by' the Solons of a conntry bench. Yet the ease was palpably within the meaning of the act. 
The long projecting bill passing easily through the interstices of the yielding nct, the head follows of course, and cvery succeding struggle tends only to cntangle them the more; and so unsuspicious of danger are they, or unobservant of the fate of their fellows, that they will often blindly fly against a net from which several of their comrades are ahready vainly endeavouring to extricate themselves. This kind of poaching is very successful when conducted by experienced hands, who contrive to arrange their nets so as to answer a double purpose, at the gateways on the borders of large woods, where many hareswhich, like woodcocks, wander in search of food during the night-are captured in the lower meshes.

But the most ancient mode of taking the woodcock was by means of the springe, although the use of this invention in its original simplicity may now be said to be almost obsolete. Nooses of platted horse-hair have superseded the single slip-knot of cord, and instead of the prize being suspended aloft from the extremity of a tall rod, its strangulation is effected by a more sceret and quiet process. When its breast las touched the horizontal stick, which may be termed the trigger of the springe, the latter is released from its curved position, and the bird 
- generally noosed round the neck-is dragged down to a peg half concealed in the ground through a hole in which the horse hair passes -and forcibly strained against it until life is extinct. But there was something far more simple and picturesque in the old springe of our forefathers: the materials for constructing it were chiefly to be found on the spot, and, indeed, consisted of little else than a few sticks and a string. Perhaps the common contrivance for taking moles, still used in most of the southern counties of England, approaches more nearly than any other to the ancient springe, of which indeed it may be said to be a subterranean rariety : but this, too, is gradually making way for a successor in the shape of an elongated toothless gin, which is much admired by the enemies of this really useful little quadruped - far blinder in their generation than the animal that they persecuteas no practical dexterity is necessary in its management; its principle is within the comprehension of a ploughboy, and erery tiller of the soil may now be his own mole-catcher.

I had once, and but once, an opportunity of secing a woodcock taken in a real old English springe. I was staying several years ago with a friend who resided in one of the most picturesque tracts of the forest range of Sussex, 
where the soil in an agricultural point of view is poor and barren, and the few arable fields that meet the eye can hardly repay the labour of the husbandman. 'The surface of the country, however, presents great variety of scenery. Hills and glens of heather, studded with hollies and yew trees, are seen in all directions, and contrast with the russet foliage of the great oak woods which form the principal feature in the landscape; while extensive commons, covered with gorse and planted with Scotch fir, are perhaps succeeded by moors of alders and willows with dark deep-looking ponds, the margins of which are hemmed in by reeds and sedges; and over this varied and thinly peopled district the black grouse, the pheasant, the partridge, the woodcock, the hare, and the rabbit still roam, almost in a state of nature, and, with the exception of the first, in sufficient numbers to reward any true and unspoiled sportsman.

One morning, just as we were preparing to take the field, a live woodcock was brought into the yard by a rough-looking native, whose appearance strungly reminded me of Leatherstocking in "The Prairie.' He was a tall and sinewy old man, with a weather-beaten countenance. His grey head was covered with a hare-skin cap. He wore a threadbare velveteen shooting coat, while 
his lower garments were almost concealed by long leather gaiters, which reached high above the knees and bore unmistakeable evidence of having protected the bony legs of their owner from many a bush and bramble. He was a sort of cross between a woodman and a poacher, with a touch of the keeper; being occasionally employed as a beater and nightwatcher, and as a trapper of all kinds of four-footed vermin, in which department he was still without a rival in the neighbourhood. After a few questions, I found that he had caught the bird in an adjoining moor, and that his apparatus was evidently nothing else than the simple springe which had been in use for centuries, and which in this remote district had not yet been superseded by any more elaborate contrivance. As I had long wished to witness this ancient mode of taking the woodcock, I gladly arailed myself of his proposal that we should make the trial that very evening; so having arranged to meet at the corner of a certain wood a little before twilight, I parted from my new acquaintance for a few hours.

At the appointed time I found him waiting for me. He conducted me along a small stream which ran between ligh wooded banks, until, at last, on clearing the cover, it opened 
upon a long narrow moor, which formed the bottom of a glen, bounded on one side by a steep declivity covered with heather, and crowned with a few firs and hollies, and on the other by a hanger of stunted oaks; while a thick bed of osiers, mingled with sedges and tussocks of coarse grass, bordered the edge of the narrow stream as it crept slowly through the middle of the little valley.

We soon found many tracks of the woodcock on the black mud; and on one spot these, as well as the borings of his beak, were very numerous. Here my companion halted, and pulling out his knife, eut down a tall willow rod, which he stuck firmly into the ground in nearly an upright position, or perhaps rather inclining backwards. On the opposite side of the run he fixed a peg, so as to project only a few inches above the surface: to this he fastened a slight stick about a foot long, attached loosely with a tough string, much as the swingel of a flail is to its hand-staff: another branch of willow was bent into an arch, and both ends driven into the sof: ground to a considerable depth on the opposit sicle of the track, and nearer to the tall uprigh. wand. 'To the tip of the latter a string was now fastened, the end of which was formed into : large rumning noose; while, about half-way down, 
another piece of stick, about six inches long, was tied by its middle. The flexible wand was then bent forcibly downwards, one end of the little stick overhead was passed under the arch, while it was retained in this position, and at the same time the bow prevented from springing upwards, by its other extremity being placed against a notch at the end of the stick which had been fastened to the peg on the other side of the run, across which it now lay, two or three inches from the ground, and supported the noose. This, in fact, constituted the trigger, which was to be released when struck by the breast of the woodcock.

The old man constructed the trap in much less time than I have taken-and how imperfectly-to describe it. Indeed, I feel that it is a subject better suited to the pencil than to the pen.

His last care was to weave the sedges on either side of the run into a kind of screen so as to weir the woodcock into the snare, and this he accomplished with much skill and expedition. It was now nearly dark, and we separated, after arranging to mect again on the same spot early on the following morning. I arrived there, however, some time before him, and found myself threading my way through the willows just as the grey dawn was beginning to appcar on the 




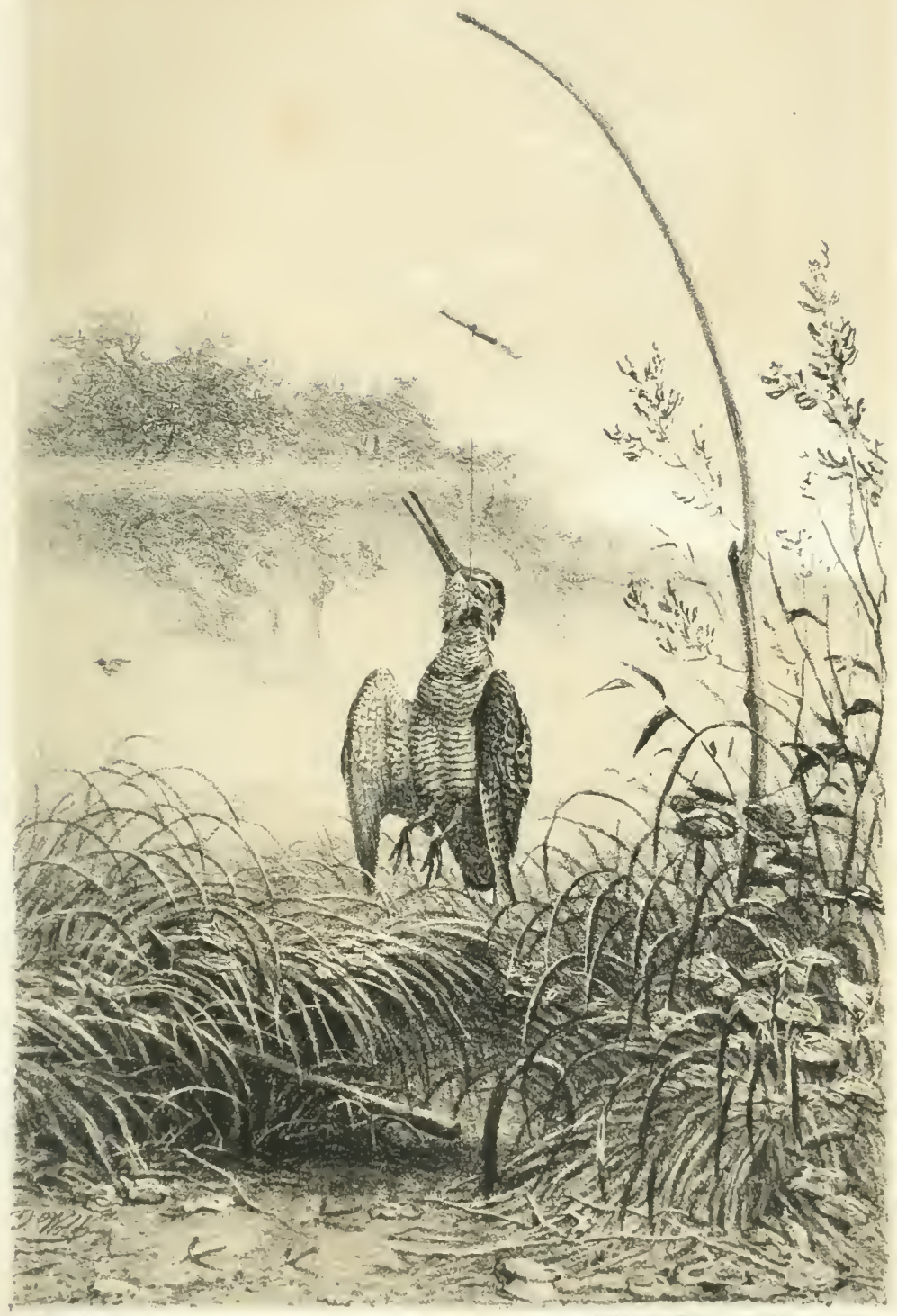



eastern horizon. Nor was I long kept in uncertainty, for on emerging from the sedges, there hung daugling before my eyes, suspended like at gibbeted felon in mid-air-a woodcock. He was noosed round the neck, and although still warm was quite dead; and as I smoothed down his ruffled, though bloodless feathers, and admired the exquisite arrangement of his plumage, I thought he was wortly of a place in my collection. There he now occupies a conspicuous niche, and I never look at him without thinking of bygone days, the swamp in the glen, and the old poacher and his springe. 


\section{CHAPTER IX.}

\footnotetext{
"Therefore I think my eagle is so justly styled Jore's servant in ordinary : and that very falcon that I am now going to see deserves no meaner a title."-IzAAK WALTON.
}

Falconry - Youthful Attempts in the 'Noble Art' - Heron Hawking-The Look-out-The Chace-An Irish BogFabulous Errors-Nagpie Hawking - Colonel Bonham's Hawking Experiences - Scardroy - Peregrine FalconsGrouse Hawking-Russian Setters-The Goshawk compared with the Peregrine-Their respective Merits-How does the Falcon strike her Quarry? - Woodcock Hawking - Convincing Fact-Anecdote-The Falcon's last Flight - 'Falcon' and 'Tiercel' - Wild Duck, Blackcock, and Ptarmigan Hawking-'Playing' the HawksThe Falcon at Sea-Recognition and Recorery.

Mr experience with trained falcons has been comparatively slight, although when quite a lad I succeeded in reclaiming the peregrine and the merlin. The field of my operations was in a remote part of the West of Ireland, where a great cxtent of preserved nountain and moorland afforded abundance of quarry, and plenty of elbow-room for the experiment; but the result never equalled my hopes. Just, perliaps, as one 
of my most promising hawks would have nearly completed its course of instruction, an absence of some months would break the tender tie, and on my return I had generally the mortification of finding either that she had perished from neglect or improper food, or that her feathers were in such a state as to render her useless in the field until another moult had taken place. Yet in justice to these juvenile attempts I must add that my proeeedings were conducted on the most orthodox system. 'There was no lack of blackletter authority. Sundry rare and valuable treatises on 'the noble al't of falconrie' had fallen into my hands, preeminent among which was a copy of 'The Book of St. Alban's,' a treasure which was reluctantly lent to me by a relative who was curious in mediaval literature, and who never lost an opportunity of assuring me that the quaint old volume was really a diamond beyond all price. Thus I soon became thoroughly initiated in all the mysteries of the hood and the leash, and even learned in a short time to fabricate my own rude tackle. Uninterrupted leisure from other pursuits, the aid of an experienced assistant, and dogs regularly trained to the sport, were nevertheless wanting; and I soon became satisfied that without these-however great certain local advantages may be-any attempt to indulge in the 
glorious pastime of our forefathers must be little else than 'vanity and rexation of spirit.'

I have since seen a few partridges killed by a cast of well trained falcons, and was once present at the capture of a heron by the same birds. The falconer and his party-of which I was one - stationed themselves in a deep ditch or drain which traversed the edge of a large bog, over which the herons had been observed to fly very low, when returning from fishing in the neighbouring swamps and morasses. Some of us would crawl occasionally to the top of the bank, and straining our eyes to the utmost, endeavour to catch a glimpse of the quarry in the distance, as, with heavy flight, it might be seen flapping slowly along the surface of the moor, gradually nearing our position, and apparently certain of passing directly over our heads; but we were frequently disappointed. One after another did several of these magnificent birds come within what we supposed to be a moderate distance, and many and loud were our remonstrances as the inexorable falconcr still obstinately refused to liberate his hawks, and persisted in waiting for a more favourable opportunity. This at last occurred. A devoted heron, whose approach we had all regarded in breathless silence, now advanced in a direction which seemed to satisfy the scruples of even the fastidious 
' auccps.' In a second the hawks were unhooded and turned off, and the next moment were in full flight after the heron, who, taking advantage of the wind, was rapidly increasing the distance between us, and at the same time ascending to a great height in a wide curve or circular gyration; a manœurre in which he was anticipated by his more active pursuers, who were now seen to rise above him, but postponed coming to closer quarters for so long, that we were soon ruming at our best speed in the vain hope of obtaining a nearer view of the sport; while several of the party, with their eyes directed upwards, appeared to forget, or to despise the obstacles that were continually presented to their progress by an Irish bog, and were soon sprawling in a turf-pit or floundering, waist-deep, in a quagmire; so that but very few of us were fortunate enough to be looking in the right direction when the falcons, who had already 'bound to their quarry,' were now seen slowly descending together, like a feathered parachute, to the ground. For my own part, I was so lucky as to reach the spot a few moments after the falconer, and found him bestriding the prostrate heron, whose head he had secured between his knees, while he appeared to be anxiously examining his hawks to ascertain whether they had received any wound from the 
sharp beak of their adversary. As to the heron, with the exception of a slight laceration of the dorsal plumage, he seemed to have suffered no injury. He was therefore reserved as a trophy, and doomed, poor fellow, to be turned out soon afterwards for the amusement of a larger party of spectators.

By the way, there are two fables comnected with the habits of the heron, yet both of them pass current with the greater part of the world as established facts in its natural history. One is, that he presents his beak to his enemy so as to transfix him when the latter is about to 'stoop.' Indeed the awkward and lumbering movements of the heron at this critical moment show that even if he were disposed to try the experiment, he has no power to bring this formidable weapon into play against his swift and vigorous antagonist, whose mode of attack indeed, as well as the rapidity of its execution, would render such a result exceedingly improbable; for the swoop is made obliquely, not perpendicularly, and the falcon strikes her quarry from bchind. When the falcons and the heron have reached the ground, then matters assume a different aspect. The moment he finds himself on terra firma he shows a bold front, and struggles to be revenged on his persecutors by well-directed and quickly 
repeated plunges of his sharp and dagger-like beak. Then indeed must the falconer hurry to the spot, or he may find that his hawks have 'caught a Tartar.' A mortal wound, serious laceration, or the loss of sight, might be the price of victory. The heron always aims at the eye. I am acquainted with a gentleman who was deprived of one of the organs of vision by a bird of this species which he had incautiously seized after it had been wounded. I have elsewhere recorded a narrow escape of my own from a similar misfortune, ${ }^{*}$ and I shot for two seasons in Ireland over an old pointer-and a capital dog he was-whose loss of one eye was attributable to an imprudent attack during his younger datys on a winged heron.

Another popular error in comnexion with this bird is that during incubation it is in the habit of protruding its legs through two holes in the bottom of its nest. Now there is no reason in the world why the heron should assume an attitude so painful and umnatural. Its legs are certainly long, but the bones of which they are composed - the femur, the tibia, and the tarsusbear the same relative proportion to each other as in the generality of waders, and can be as easily folded up underneath the body as the legs of any other bird. Perhaps the story may have origi* 'Ornithological Rambles in Sussex.' 
nated in the brain of some compiler who was ignorant of its anatomy, and who had never seen its nest; but having noticed the unusual length of its limbs, took for granted that it would be impossible for the heron to gather them up in the usual manner, and therefore as there ought to be two apertures in the bottom of the nest for their reception, that he might take the liberty of boring them forthrith. One of the numerous instances in which preconceived theories are found to be at fault when tested by the actual operations of nature.

But besides the noble heron, which formerly occupied a prominent position on the game list, and many other birds which are now included in that category, various species of wates-fowl and wading-birds were farourite objects of pursuit with the falconer. Nay, even crows and magpies had their admirers, and in the opinion of the late Sir John Sebright-one of the highest authorities on that subject-the last-named birds afford so animating a sport that he considered it far superior to every other kind of hawking. The magpic always endeavours to make for a thick hedge or cover. The object of the falconer, and indeed of all the spectators-whose assistance is of importance, and who are thus enabled to take a share in the amusement-is to drive him from these 
strongholds into detached bushes, and in passing hurriedly from one to the other the falcon makes her stoop, while her quarry exhibits great dexterity in avoiding the fatal blow. Excellent sport of this kind has been afforded by the falcons of Y. O'Keefe, Esq., at the Curragh of Kildare. On one occasion the magpie, after having been successively expelled from various places of retreat, made for a distant whinbush, and when about half way across the intervening space, seemed to elude the stroke of the falcon by suddenly dropping to the earth and disappearing from all his foes; for when the party arrived on the spot the magpie was nowhere to be found. The ground was carefully examined where he had so mysteriously vanished, and whips were loudly cracked by the mounted spectators; but all in vain. Here was a puzzle! The falcon still continued to 'wait on' overhead, a sure sign that her quarry was underneath her. At last, after a long scarch, he was found snugly concealed in the bottom of a cart-rut, where, but for his treacherous plumage, he would probably have succecded in escaping the observation of his enemies.

On another occasion one of the falcons belonging to this gentleman afforded a remarkable example of the extraordinary height to which it will occasionally compel its quarry to ascend, and of 
the determination and perseverance with which is will pursue it to such an altitude, before it succeeds in dealing the fatal blow. This time a crow was the object of the chace, and 'took the air' immediately, hotly pursued by the falcon, and soon rose to such an elevation in spiral sweeps directly abore the head of the spectator, that both birds were gradually lost to his riew. Another minute elapsed, during which he continued to strain his eyes in rain in the hope of catching a glimpse of them in the direction where they had lately vanished from his sight. At last a single dark speck appeared, which quickly became larger and larger as it descended, and the next moment the dead body of the crow fell with extraordinary force a few yards from the spot on which he was standing.

Perhaps few men in these degenerate days have had such opportunities of enjoying the glorious sport of falconry, with every advantage which art and nature could combine, as my friend Colonel Bonham, of the 10th Hussars. Those who know him are aware that a great portion of the early period of his life was deroted to 'the noble craft,' and the same cuergy and spirit which cnabled lim to overcome the numcrous obstacles to a full enjoyment of this animating pastime in the British islands, has at a later period, since serving 
with his regiment in the East, carried him into the swamps and jungles of Indostan, in spite of Thugs, tigers, and fever, and rewarded hin with the acquisition of many a sporting trophy.

Some years ago he rented Scardroy, an immensc mountain district in Rosshire, near Strathconnan, comprising an area of thirty-five thousand acres. This vast tract of wild ground adjoined, or 'marched with,'-as the Highlanders have itanother beat of similar extent, over which he had free permission to pursue his sport. The whole was well stocked with grouse, black-game, and ptarmigan, while even red-deer were found within its limits; but although a good shot and a practised stalker, the gum and the rifle were gonerally laid aside for the far more exciting sport of falconry. Would that others could be tempted to follow his example! But this is more than can be expected. I cannot however persuade myself that a short sketch of his hawking experiences will prove wholly uninteresting, even to those who prefer to take the field with the weapons of modern warfare. I therefore arail myself of his permission to embody from recollection a few of his notes and observations, sincerely regretting that I cannot add

Et quorum pars magna fui." 
Scardroy Lodge was a long low building situated in a gorge in the very heart of the Highlands. In front a broad belt of moorland sloped down to the clear waters of Loch Benachran, which was well stocked with trout, and haunted during certain seasons by wild ducks and various species of water-fowl. Lofty mountains rose from the opposite side of the lake, gradually ascending higher and higher until the heathery brows were at last succeeded by the grey rocks, where the red grouse gave way to the ptarmigan. Still farther to the right the hills appeared to be abruptly severed, and frowned over the water, in which their image was distinctly reflected. Opposite to them, and nearer to the lodge, a rapid river rushed into the lake, after wandering through a wilderness of moor in the rear, and watering many a secluded valley, where the crack of the rifle was seldom heard, and where the lazy stag might slake his thirst in undisturbed security. Such was Scardroy: and here with an experienced falconer and trusty keepers, his hawks and his dogs, Colonel Bonham took up his quarters, and passed a great portion of many years in the full enjoyment of his farourite pursuit. He had at one time as many as twelve peregrines, most of which he had obtained on the northern coast of Ireland. Certain lofty cliffs in the counties of 
Derry and Antrim were favourite breeding places. Some were from the cliffs of Benerenagh, others from Fair Head, Tory Island, and the Giants' Causeway. The isle of Arran had at different times furnished him with fine hawks, as well as Rathlin Island and Geron Point, and Imnishowen on the coast between Loch Foyle and Loch Swilly. He had also procured peregrines from a certain inland precipice on the property of Mr. Cole Hamilton; but although most of them were obtained from Ireland, some came from the North of Scotland, among which he particularly remembered a favourite bird from Ailsa Craig.

Next to good hawks, an efficient falconer and plenty of elbow room, well-trained dogs were of the greatest importance. Long experience had satisfied Colonel Bonham that a variety known by the name of Russian setters were better adapted for this sport than the common setter or pointer. He found them far more docile and sagacions, yet equally spirited; and they possessed the inestimable advantage of not being spoiled as shooting dogs by the unavoidable indulgences and licences which were permitted during a day's hawking. This may be best illustrated by a seene of ordinary occurrence. The setters have found game. The falconer advances with his hawks unhooded and ready to start from his fist. Now 
they are on the wing, and allowed to attain a considerable elevation before the grouse is flushed. The dogs are still motionless, or perhaps occasionally avert their steady gaze for a moment from the crouching bird, and cast a hasty glance upwards. At last the falconer kicks up the grouse, who flies away at his best speed with the hawks close behind him. Away too go the falconer and the colonel. Who thinks of 'down charge' at such a moment, or who could expect the dogs to practise such self-denial when their preceptors have set them so bad an example? Away go the dogs also, each pursuer anxious to be in at the death, and valuable allies do they prove. The falcons and their quarry have disappeared over the brow of a hill, and the setters are out of sight, for the sportsmen are far behind. At last on arriving at an elevated spot they see a wide valley beyond them; but where is the grouse? and where are the lrawks? The chace is over, for the far-sighted falconer can see nothing of the birds in the air. He now scans the heather below, and soon perceives old Platoff, with tail extended and rigid as a statue, backed by his companion. Hurrying down until within a moderate distance, he utters the well-known shout, and tosses his lure aloft; while he now cantiously advances towards the spot where, half 
concealed in the heather, the female hawk or falcon-cowers over the fallen grouse, and cunningly endeavours to screen it from discovery with her extended wings, while the male-or tiercel - waits patiently until his Patagonian partner shall have so far satisfied her appetite as to allow him to partake of the repast. Here the falconer will exercise his judgment. If a second flight is contemplated he will gradually secure the quarry, and reward his hawks with a few mouthfuls of meat from the lure; but it will be advisable for him occasionally to leave them in undisturbed possession of their prey, or they will contract the bad habit of attempting to 'carry' it away on his approach. According to Colonel Bonlam three grouse are sufficient to take from a falcon in one day.

But to return to the dogs, who have acted their part to perfection, and have been as immoveable as the surrounding rocks during the process of feeding and securing the hawks, and releasing the grouse from their grasp. One might expect that if taken out with the gun on the following day their performance would be less creditable. No such thing. 'T'hese Russians were capable of distinguishing and appreciating the nature of the different characters in which they were alternately required to appear, and when the game was sprung 
and the bird fell or flew away, no attempt was made, no inclination was evinced to break the point; but they would 'down charge' as instantaneously and perfectly as if the discipline usual in such cases had never been for a moment relaxed. Nay more, two of them used to act regularly as retrievers when the word was given to follow a wounded bird. Colonel Bonham said that both of these were good field dogs, and one of them the very staunchest that he ever possessed.

Besides his favourite peregrines, Colonel Bonham obtained a pair of goshawks which were bred on the Duke of Gordon's estate at Fochabers; but he found them of little use in the open country about Scardroy. The goshawk is shortwinged; his flight is close to the ground, and, compared with that of the falcon, tedious and uninteresting. $\mathrm{He}$ is in fact a sparrow-hawk on a larger scale, and was accordingly included in the same sub-genus (accipiter) by naturalists, until Cuvier, observing the comparative shortness and stoutness of the tarsi and the moderate length of the middle toe-which in the sparrow-hawk is considerable-formed a separate genus (astur) for its reception. The habits of the goshawk are as different as its conformation from those of the falcon. Instead of soaring to a great height and 
descending in a swoop upon its prey, it pursues it in a direct line, and after driving it into a bush or cover, takes up its own position on the nearest tree, where it waits patiently until hunger or necessity compels the poor bird to leave its place of concealnent; when eat-like it darts upon its victim, and secures it without difficulty. It is accordingly better adapted for a wooded or enclosed country than the peregrine; for pheasants and partridges than for grouse or ptarmigan. Its character too is altogether devoid of that energy and perseverance that are so conspicuous in the falcon. If the quarry should gain an advantage at the beginning of the chace, it frequently relinquishes the pursuit altogether, and settling on the nearest branch, prepares to dart upon the next passer by. It was not without reason therefore that this species, and some other hawks of similar structure, habits, and character, were styled 'ignoble' by our ancestors, to distinguish them from the long winged, high-flying or 'noble' falcons. The movements of the goshawk however in cover are exceedingly rapid and effective. Its short wings enable it to pass more easily through the intervals of the boughs, while with its long and fan-like tail it steers its way, and performs marvellously intricate evolutions as it pursues the pheasant, the blackeock, the hare, or 
the squirrel through the tangled labyrintlis of the coppice and underwood.

The red grouse was a farourite object of the chace with Colonel Bonham. Sometimes it would drop suddenly and take refuge in the heather, when the falcon would abruptly check her progress, and ascend rapidly over the spot where the bird had sought concealment. This in the language of the craft is called 'making the point.' When the falconer perceives this from a distance, he hastens to the spot, and if the hawk be not already thoroughly trained, he lures her down for the purpose of accustoming her to that invaluable aid, after which he has the opportunity of affording her a second flight; but if an old or thoroughly broken falcon, he has only to start the grouse from the heather while she waits on overhead, and away she goes after it again. It not unusually happens however that the poor grouse is so scared and umnerved by the aerial movements of its deadly foe, that it will suffer itself to be captured under the very nose of the dog rather than venture to take wing a second time.

The best chance of escape for the grouse is when he is sprung near the foot of a mountain, and continues to work up hill, without deviating considerably to the right or left. On such occasions the falcon scldom succeeds in striking him 
effectually. On the contrary when lie is found on the higher brows, and makes for the valley, then his fate is sealed. The hawk is up with him in a moment, and strikes him like lightning.

The peregrine often showed a repugnance to pursuing her quarry across a large piece of water. This was most frequently evinced when wild ducks were the objects of the chace. Sometimes, however, a high-mettled hawk would keep within a certain distance of the bird during the transit, and if the duck, instead of dropping on the water, or seeking shelter in the reeds or rushes on the opposite bank, continued its flight over the moor beyond, she would resume the pursuit with undiminished ardour.

It has often been a question with ornithologists, in what precise manner the falcon deals the fatal blow. Some authors have asserted that it is by means of the foot; others attribute it to the breastbone, protected as it is by such strong pectoral muscles that the concussion which is supposed to deprive its victim of life can have no injurious effect upon the author of the momentum. My own opinion, which is fully corroborated by the more extensire experience of Colonel Bonham, is that it is by means of the powerful hind talon that the deadly wound is inflicted. If a gronse, a duck, or a woodcock that has been 
thus suddenly killed by a peregrine be examined, it will generally be found that the loins and shoulders are deeply scored, the back of the neck much torn, and even the skull sometimes penetrated by this formidable weapon. Now as the stroke is almost always delivered obliquely, that is, in a slanting, downward direction from behind, this laceration could not be effected by any of the talons of the front toes; nor would the severest possible blow from the breast of the falcon produce such an effect. Indeed, Colonel Bonham had several rare opportunities of witnessing the operation distinctly, and his testimony on this point ought to be conclusive. On one occasion in particular, when in Ireland, a woodcock, after a long chace over an adjoining moor, had taken refuge in a small corer, whither it was closely pursued by the hawk-the falconer and several assistants following. Colonel Bonham himself made for a nearer point of the coppice, and had just taken up his position under a tree at the side of a ride or alley, when he saw the woodcock flying towards him, and its enemy close upon it. As the former passed within a few yards of the spot where he stood, he perceived by its laborious flight and open beak that it was much exhausted. The next moment down came the falcon, and he could see distinctly that the blow was delivered 
by the hind talons. The effect was instantancously fatal, and preciscly such as might have been expected from the nature of the weapons that were brought into play. The back of the woodcock was completely ripped up, and the lower part of its skull split open.

Sometimes a woodcock would 'take the air,' that is, endeavour to escape from its pursuer by ascending to a great height in circular gyrations; and being a bird of considerable vigour and rapidity of flight, it was, in the performance of this manœuvre, almost a match for the peregrine. There is much danger of losing the falcon on such occasions, for as soon as the woodcock has attained a certain altitude, it will-especially if favoured by a fresh breeze-strike off in a direct line, and lead the hawk a distance of many miles. Of this, Coloncl Bonlam mentioned a remarkable instance, which is well worthy of being recorded.

When hawking for woodcocks in Rossmore Park, in the County of Monaghan, Ireland, with the Hon. R. Westenra, a woodcock, after a short chace, ' took the air,' closely pursued by the falcon-the property of the latter gentlemanwho had her bells and 'varvels' on, with the name and address of the owner engraved upon them. In a short time both birds had attained 
such an elevation that it was only by lying down on their backs, and placing their hands above their eyes, so as to screen them from the rays of the sun, and at the same time contract the field of rision, that the spectators could keep them within view. At last, just as they had become almost like specks in the sky, they were observed to pass rapidly towards the north-east, under the influence of a strong south-west wind; and were soon completely out of sight. Some days elapsed without any tidings of the truant falcon; but before the week had expired, a parcel arrived at Rossmore Park, accompanied by a letter bearing a Scotch postmark. The first contained the dead body of the falcon: the latter the closing chapter of her history from the hand of her destroyer, a farmer who resided within ten miles of Aberdeen. He was walking through his grounds when his attention was attracted by the appearance of a large hawk which had just dashed among his pigeons, and was then in the act of carrying one of them off. Ruming into the house he returned presently with a loaded gun, and found the robber coolly devouring her prey orl the top of a wheat-stack. The next moment the poor falcon's wanderings were at an end; but it was not until he had seen the bells on her feet that he discovered the value of his 
victim, and upon a more careful cxamination perceived the name and address of her owner; and while affording him the only reparation in his power by sending him her remains and the account of her fate, he unconsciously rendered the story worthy of record in a sporting and an ornithological point of view; for upon a subsequent comparison of dates it was found that she had been shot near Aberdeen, on the eastern coast of Scotland, within forty-eight hours after she had been flown at the woodcock in a central part of the province of Ulster in Ireland.

Colonel Bonham has known as many as fifty woodcocks procured in the same scason by one peregrine. A much greater number had, of course, been killed by her, but it is advisable to leave the hawk in undisputed possession of her prize occasionally, or she would soon acquire the bad habit of carrying it off on the approach of the falconer, as however great may be the attractions of the lure, they are far surpassed by those of the natural prey which she has obtained by her own unassisted powers.

In all raptorial birds the female is larger and more porrerful than the male, and in this species is styled the falcon, par excellence, the male the tiercel. It is not advisable to fly two hawks of the same scx at once, but a falcon and tiercel 
who have become accustomed to each other, may be started together. In such a case, when the quarry has been struck, the male will give way to his more potent helpmate, and she will keep possession of the bird until the arrival of the falconer; but the result may be very different when two hawks of the same sex join in the pursuit: they may occasionally be found fighting desperately for the prize, even when it has effected its escape, after leaving nothing but a handful of feathers to reward the successful combatant.

Colonel Bonham found that no bird was so easily killed by the falcon as the common wildduck, which he attributed to its direct and uniform flight, unvaried by those sudden shifts and dodges which are so frequently practised by the grouse and the woodcock. It was his custom to mark down a party of ducks at some turn or angle of the river, where the banks were sufficiently steep to admit of his near approach with the hawks. When the alarm was given they sprang from a moderate distance, and a good falcon not unfrequently killed a mallard at the very first blow. He had previously obscred that the old male black-cock often contrived to escape after having been struck, and would then take refuge in a thick bush or cover, into 
which a young tiercel would occasionally pursue him and luunt him out again: but the falcons soon became too cumning or too proud to enact the part of a terrier, and preferred to wait on overhead until the quarry had been started for a fresh flight. Grey hens, however, and young males, were easily killed.

The sport which required most energy and perseverance, and was attended with greater danger and difficulty than any other, was ptarmigan hawking. It might be compared to chamois shooting. The haunts of the ptarmigan were among the highest of the rocky peaks that crowned the lofty mountains near Scardroy. Besicles the obstacles which the precipices and the rugged nature of the ground presented at every step, it was no easy matter to find the birds, so closely did they lie; and so exactly did their plumage resemble the colours of the lichens and surrounding crags, that without good hardy dogs the attempt would have been unsuccessful. Even after this had been accomplished, the game started, and a bird struck down by the falcon, it would frequently fall over a tremendous cliff; and a détour of some miles must be performed before the ptarmigan could be found or the liawk recovered. As in all analogous circumstances however, where danger and difficulty beset the path of the sportsman, 
the pleasure of success was commensurate with the risk encountered.

It was a practice with Colonel Bonham to 'play' his hawks occasionally, having previously taken the precaution of 'half feeding them up,' and allowing the brass swivels by which the leashes are attached to the 'bewits,' or rings, to remain on their feet, which thus proved a sufficient ballast to prevent them from indulging in long protracted flights. Nothing, he assured me, could surpass the calm delight with which on a fine autumnal evening he used to lie stretched on the heather near the lodge, and contemplate for hours the graceful aerial evolutions of his falcons. Occasionally the passage of an imprudent hooded crow would excite them to a short chace, and after a good buffetting they would allow him to pursue his way without further interruption. Sometimes two or three would meet together in mimic combat, and with loud screams cleave the air in a rapid descent, or tumble headlong towards the ground, until suddenly arresting their dornward course they would reascend to the higher regions in gradual gyrations, and continue to soar aloft, or repeat their manœurres until it was time to call them down from their 'play.' 'Then the falconer would appear with his lure, and sweeping it round his head and shouting at the same time 
in a peculiar key, the hawks would descend from abore with closed pinions, and having received the reward of their obedience in the shape of a few tempting morsels of raw meat, quietly suffer themselves to be hooded, and once more placed on their respective blocks.

It has been frequently asserted that the peregrine is not susceptible of personal attachment, that hunger is the sole agent by means of which the falconer is enabled to reclaim her, and that it is to the lure, and not to the person who wields or displays it, that she evinces partiality or regard. The following anecdote, however, would appear sufficient to rescue her character from such an imputation.

A friend of Colonel Bonham-the late Colonel Johnson of the Rifle Brigade - was ordered to Canada with his battalion, in which he was then a captain, and being very fond of falconry, to which he had devoted much time and expense, he took with him two of his favourite peregrines, as his companions across the Atlantic.

It was his constant habit during the voyage to allow them to fly every day, after 'feeding them up ' that they might not be induced to rake off after a passing sea gull, or wander out of sight of the ressel. Sometimes their rambles were very wide and protracted. At others they would ascend 
to such a height as to be almost lost to the view of the passengers, who soon found them an effectual means of relieving the tedium of a long sea voyage, and naturally took a lively interest in their welfare, but as they were in the habit of returning regularly to the ship, no uneasiness was felt during their occasional absence. At last, one erening, after a longer flight than usual, one of the falcons returned alone. The other - the prime favourite - was missing. Day after day passed away, and however much he may have continued to regret his loss, Captain Johnson had at length fully made up his mind that it was irretrievable, and that he should never see her again. Soon after the arrival of the regiment in America, on casting his eyes over a Halifax newspaper, he was struck by a paragraph announcing that the captain of an American schooner had at that moment in his possession a fine hawk, which had suddenly made its appearance on board his ship during his late passage from Liverpool. The idea at once occurred to Captain Johnson that this could be no other than his much-prized falcon, so having obtained immediate leave of absence he set out for Halifax, a journey of some days. On1 arriving there he lost no time in waiting on the commander of the schooner, announcing the object of his journey and requesting that he 
might be allowed to see the bird; but Jonathan had no idea of relinquishing his prize so easily, and stoutly refused to admit of the interriew, 'guessing' that it was very easy for an Englisher to lay claim to another man's property, but 'calculating' that it was a 'tarnation sight' harder for him to get possession of it; and concluding by asserting in unqualified terms his entire disbelief in the whole story. Captain Johnson's object however being rather to recover his falcon than to piek a quarrel with the truculent Yankee, he had fortunately sufficient selfcommand to curb his indignation, and proposed that his claim to the ommership of the bird should be at once put to the test by an experiment, which several Americans who were present admitted to be perfectly reasonable, and in which their countryman was at last persuaded to acquiesce. It was this. Captain Johnson was to be admitted to an interview with the hawk-who, by the way, had as yet shown no partiality for any person since her arrival in the New World, but on the contrary had rather repelled all attempts at familiarity - and if at this meeting she should not only exhibit such unequivocal signs of attachment and reeognition as should induce the majority of the bystanders to believe that he really was her original master, but especially if she 
should play with the buttons of his coat, then the American was at once to waive all claim to her. The trial was immediately made. The Yankee went up stairs, and shortly returned with the falcon; but the door was hardly opened before she darted from his fist and perched at once on the shoulder of her beloved and long lost protector, evincing by every means in her power, her delight and affection, rubbing her head against his cheek and taking hold of the buttons of his coat and champing them playfully between her mandibles, one after another. This was enough. The jury were unanimous. A verdict for the plaintiff was pronounced: even the obdurate heart of the sea captain was melted, and the falcon was at once restored to the arms of her rightful ormer. 


\section{CHAPTER X.}

"For if a hope of safety rest,

'Tis in the sacred name of guest,

Who sceks for shelter, storm distress'd,

Within a chieftain's hall."

WALTEE ScotT.

Favorite Haunts of the Pheasant in a state of Nature $-\boldsymbol{A}$ morc general Distribution of the Species desirable Inefficiency of the Game Laws-Importanee of a quiet and secure Place of Retreat-Asylum for Pheasants at Walton Hall - Descriptive Sketeh - Crowing of Coek Pheasants - Seenery - Valley of the Rother - Singular Oceurrenee-Importanee of Evergreen Timber Trees in Preserves.

Extensive oak forests and woods affording a considerable surface of ground cover, intersected by shallow streams, appear favourable to the pheasant in a state of nature. Thus in parts of Austria, Bohemia, and Bavaria they have been known to increase more rapidly and to acquire a firmer footing than even in some of the agricultural counties of England where every pains has been taken to establish them. This may be still further attributable to the greater strictness with which the game laws and forest regulations of the 
Continent have been generally enforced, as well as to a comparatively scanty population, and the absence of those luxuries and incentives to crime which too frequently follow in the wake of refinement.

It is admitted by all who deserve the name of sportsmen, that a general distribution of the pheasant throughout the length and breadth of the land, would tend more to a desirable result than the concentration of the species within the narrow limits of an overcrowded preserve. Without any reference to the manufacturing districts, where indeed the thing would appear to be almost impracticable, there are still vast tracts of country in the agricultural parts of England where the bird is almost unknown, and yet where, by a little care, and the cordial cooperation of all who have an interest in the soil, it might be established in moderate numbers. It may be objected that the strict administration of the existing game lawsinefficient as they are-would be attended with such a degree of odium that the experiment, even if successful, would not be worth the trialthat 'le jeu ne vaut pas la chandelle'-that they will probably soon be materially altered or repealed. Granted. But as long as they remain on the statute book, the judicious exercise of their provisions may generally be safely adhered to, and 
prospective legislation has nothing whatever to do with the subject of the present chapter. Even in an ornithological point of view the pheasant is a most interesting bird. There is many a walled and wooded park, to which he is now a stranger, where he might be easily introduced and established, simply by providing him with suitable food and secure places of retreat and concealment at ail seasons of the year, almost without having recourse to the modern system of preservation, or the interrention of keepers and game laws.

During a delightful visit which I paid lately to Mr. Waterton, at Walton Hall; among the thousand objects of interest that crowd upon the attention of the naturalist, I had the gratification of seeing an asylum for pheasants planted about twenty years ago, and which now appears to be the very beau ideal of everything that could be wished for in that way. Local circumstances indeed, orer which he had no control, induced lim some years since to relinquish the preservation of those birds on his property, but I rejoiced to learn from him that it is his intention shortly to introduce a sufficient number to add to the interest of a scene that already possesses so many ornithological attractions, and to occupy a spot where, as soon as they have arrived at years of discretion, they may equally laugh 
to scorn the cat, the stoat, the fox and the poacher.

This paradise for pheasants is situated in an open part of the park, not far from the lake. A thick hedge of holly surrounds a clump of yew trees, in an oval form, and is rendered still more secure by a ditch which encircles it externally. This holly hedge is regularly clipped and quite impenetrable from top to bottom; being in fact an evergreen wall, and the only entrance is by a small gate which is carefully locked. Within, a narrow space intervenes between it and the yew trees, which being also constantly cut on the top and underneath, have so spread and interwoven their lateral branches as to form a dense verdant canopy overhead, through which not a single ray of light can penetrate. To enter this evergreen grotto it is necessary to stoop very low through a little archway cut in the thick foliage, but when once arrived at the interior a man may stand almost upright. Then, and not until then, the advantages of the place as an asylum for pheasants become evident. There is no under cover or brushwood, and therefore no inducement to the birds to sleep on the ground where they too frequently, in less faroured spots, become the prey of nocturnal four-footed rermin; while the horizontal branches of the yew trees afford every- 
thing desirable in a roosting place. Even during the day it would be difficult to perceive a pheasant when perched among them. If notwithstanding all these obstacles to the ingress of an unwelcome visitor, one should succeed in reaching the centre of the clump and alarm the pheasants, they would drop quietly from the branches of the yews upon the smooth ground, and running through the hollow space below towards the exterior, arrive at once in the narrow passage between them and the holly hedge where there is sufficient room to enable them to start from the ground, and their first appearance from the outside would be just as they topped the summit in a rapid flight to another place of security. Such a spot is of course secure from the depredations of the night shooter; and the impenetrable nature of the hollies, through which even the pheasants themselves cannot force a passage, baffles at the same time the machinations of the wirer and trapper.

I was delighted to see a second clump of the same sort at some distance, which has been planted about five or six years, and promises to equal that which I have attempted to describe, when it lias seen as many summers.

It may be objected that the length of time that must elapse before it can arrive at perfection, is a serious drawback to the practical utility of such a 
perfect retreat for pheasants. But surely this consideration ought not to influence those who have it in their power to create them on their ancestral domains, and who have a park or landed property of any kind to bequeath to their successors. The first expense and labour are comparatively trifling; and beyond these there is no difficulty. They may be laid out on any open space of ground that has the advantage of water in its neighbourhood; may be planned of any size, and multiplied to any extent, according to the dimensions or capabilities of the park or estate. Food should be liberally supplied. It should be placed inside, under the yew trees. Jerusalem artichokes, boiled potatoes and beans are better than barley or buckwheat, not being liable to be devoured by sparrows and other small granivorous birds which have a strong precailection for all kinds of cereal grain.

The importance of evergreen timber trees in extensive preserves has becn too much orerlooked in general. I am not now alluding to yews and hollies, which take many years in coming to perfection, or at least before they can form secure roosting places for pheasants. Scotch, spruce, and silver firs ought to be planted liberally. A well-known and frequently fatal habit of the cock pheasant-that of crowing sevcral times when he 
first ascends to his roosting place in the evening, and so giving notice of his whereabouts to the attentive poacher-would thus be in a great measure neutralized. I speak from personal experience when I say that it is impossible, even with the aid of moonlight, to perceive the form of a pheasant among the upper branches of a fir tree, while on the darkest night $I$ have succeeded in discerning his profile against the sky among the leafless boughs of the oak and the ehn. But the habit of crowing, indulged in at all hours of the day during the breeding season, is not restricted to the purposes of love or the hour of rest. The same note is uttered on quitting his perch at early dawn, and the sound of thunder or distant cannon never fails to produce it. How often, though at a distance of thirty miles, have I heard it elicited by the booming of the Portsmouth guns, when the weather was calm, or the wind in a farourable quarter. But the most remarkable instance of this kind that ever came under my notice oceurred on the 11 th of March, 1850. It was a clear sunny day, the air cold and frosty, with a gentle breeze from the north-east. I had been riding through Charlton forest, and had just begun to descend the northern slope of the downs by a rugged path above the village of Graffham, when I was indueed to halt for a moment to ad- 
mire the magnificent panoramic view that here suddenly bursts upon the sight. The dark hanging woods of Lavington clothed the steep hills on one side, while on the other their natural forms were varied by smaller clumps of beech and juniper. Below me lay the long and picturesque valley of the Rother, extending from the borders of Hampshire as far as the eye could reach, and varied with wild, heathery commons, evergreen woods, brown copses, and cultivated fields. Immediately opposite was the elevated range of the lower green sandstone formation which forms the southern boundary of the weald of West Sussex; beyond which again, in the distance, might be seen the blue outline of the Surrey dorns as they stretched far away into the eastern horizon. I had not gazed long upon this magnificent scene before a deep hollow booming, or protracted concussion-for it was rather felt than heard-shook the earth for some seconds. At the same moment a pheasant in an adjoining copse announced his consciousness of the shock by a sudden crowing, which had hardly ceased before a second explosion, succeeded after another interval by a thirdthe loudest of all-induced every cock pheasant in the woods of Lavington to sound his note of alarm. As to myself, I confess I was puzzled how to account for the phenomenon. It was 
quite different from the rumble produced cven by the loudest artillery, and the clear cloudless sky forbade the supposition of its being caused by even distant thunder. On my way home I passed screral persons who had heard it, and many of whom had noticed its effect on the pheasants, especially one party of labourers who were $\mathrm{em}$ ployed in repairing a fence near a long hangerone of the best preserves in the county-they told me that a loud and long continued crowing proceeded from all parts of the wood for many minutes after the last explosion. They too were unable to conjecture the cause of the sound, nor was the mystery unravelled until the following day, when intelligence arrived of the awful explosion and loss of life at Messrs. Curtis and Harvey's powder mills at Hounslow, nearly fifty miles in a direct line from the spot where I heard it.

But to return from this digression. The rapid grow th of Scotch and spruce firs recommend them to the notice of evcry game preserver; indeed the horizontal branches and dense foliage of the latter afford at once unrivalled facilities for perching, and warm situations for roosting during the most inclement winters. I have seen the adrantages of such an experiment in a wood belonging to a friend of mine, not many miles from the spot 
in which I am now writing. If the ground underneath be covered with gorse so much the better. With gorse below and spruce firs abore, the night shooter is sadly puzzled; and I have observed that old pheasants not only prefer these trees for their roosting places, but resort to their branches at an earlier period of the evening than to the more exposed boughs of the oak, as if from a sense of the greater security that they afford. At any rate no large cover ought to be selected for the preservation of pheasants, in a country where night poaching is prevalent, that is not diversified with some clumps or patches of firs or pines. Such a precaution, with a fair supply of stuffed or wooden pheasants, stuck by wires on deciduous trees in other parts of the coppice- on which these worthies may be allowed to expend their ammunition with impunity-would greatly facilitate the nocturnal preservation of the pheasant in any district where he is already established, and might prevent many a bloody affray, and the loss of many a faithful servant in a deadly encounter with superior numbers, which must always be equally deprecated by the sportsman and the philanthropist. 


\section{CHAPTER XI.}

"Sic vos non vobis nidificatis aves."-VIRG1L.

Injuries inflicted on various Birds during the Breeding Scason -Robbery of Eggs-Plover's Eggs-Eggs of Terns and Gulls-Blackheaded Gulls-Preserves of those BirdsGullery at Scoulton-The Gamnet or Solan Goose-Wild Geese and Ducks - The Eider Duck-Its Distribution and Domestic Economy-Plunder of the Eggs and Down - Traffic in the Eggs of Rare Birds-Injurious Consequenees - Scicntific and Amateur Collectors - Eagles' Eggs - French and Duteh Purveyors - Tricks of the Trade-Depredations eommitted on Game Birds during Incubation - The Red Grouse-Feathered Bandits Grouse and 'Scaul Crows'-Poachers-The Eggr Stealer the most Mischievous and Diffieult to Detect-Indirect Encouragement thoughtlessly afforded-Pheasants' Nests - Habits of the Hen Pleasant-Tactics of the Egg Stealer-Ignorance of Game-keepers-Persecution of conparatirely Harmless Animals - Duties of a Keeper during the Breeding Scason.

Maxy kinds of wading and swimming as well as gallinaceous birds suffer more during the period of incubation than at any other season of the year. The straightforward sportsman, however successful and indefatigable he may be, nay even 
the punt-shooter with his swivel gun, who bags his two or three score at a shot, and maims and wounds even more than he bags, destroys but a tithe of the members of the feathered creation, compared with him who plies his trade during the breeding season in the woods or the swamps, the heather or the glen, the sea-girt precipices or the rocky islands where so many species love to rear their young, whose existence is too often prematurely nipped in the bud where the eggs are sought after as food or for the purposes of traffic by the neighbouring inhabitants.

As a direct and favourite article of luxury for the table, perhaps that of the peewit or lapwing (vanellus cristatus) is the best known in the British islands. The moors of Scotland and Yorkshire, the bogs of Ireland, the sandy rabbitwarrens of Norfolk, the fens of Lincolnshire and Cambridgeshire, and most of the maritime swamps of the kingdom abound with these birds in the months of April and May, and indeed there is scarcely an extensive common in any part of England, which lias hitherto escaped the draining improvements of modern agriculture, where they may not be found during the breeding season, and where a spring harvest of plovers' eggs is not amnually reaped. The grand emporium is of course the Metropolis itself, and the trade is 
carried on more briskly in those breeding stations which are moderately near to, or have a direct communication with large towns, than in remoter districts. Thus from Rommey Marsh alone, two hundred dozen were sent to Dover in 1839, the greater portion of which probably found their way to London. In that part of Kent the traffic is so profitable that dogs are regularly trained to liunt for the eggs, a practice which is not confined to that county. In the remoter districts of Wales and Ireland, however, I have frequently found lapwings during the summer, in the enjoyment of perfect immunity from man. Among the upland marshes in the unreclaimed portions of the latter country, this species as well as the golden plover and the common snipe, breed in considerable numbers. Their grand enemy there appeared to be the hooded crow, who was always on the watch ready to pounce on any nest that might have been momentarily quitted by its luckless owner, and who frequently carried off his prize transfixed on his beak, in spite of the loud cries and warlikc aerial manceuvres of whole troops of peewits, who eagerly combined in their efforts to expel the common enemy.

Like most birds of this class, the lapwing lays but four eggs, which are usually deposited in a slight depression on some partially elevated 
mound or tussock, and lined with dry grass, sedge, rushes, or twigs of heather. By the way, the prevalent notion that the eggs of the rook are frequently sold as those of the plover is without foundation-simply because they bear no resemblance whatever to each other, and even the most unscrupulous rendor would hardly dare to attempt so palpable a hoax on the least experienced of purchasers. That of the peewit is pear-shapedas is the case with most grallatores - that is to say, it is considerably attenuated at the narrower end. The ground colour is brownish olive, and the surface is blotched with large and irregular patches of rusty black. It is moreover half as large again as the rook's, which is of an oval form, the ground tint bluish green, with slate coloured and darker marks not unlike those on the egg of a blackbird - which indeed might almost be considered a miniature likeness of the rook's. The most fastidious epicure may therefore make his mind easy on this subject.

The eggs of the ruff (machetes pugnax), the redshank (totanus calidris), the golden plover, (charadrius pluvialis) and other vermivorous waders; nay even those of many species of gulls and terns bear a much stronger resemblance to the lapwing's, and no doubt frequently find their way into the market under the denomination of "plo- 
ver's eggs;' but the deception is unimportant: most of the former are quite as delieate; and even of the latter, when new-laid and hard-boiled, the flavour is unexceptionable, as I can vouch from personal experience, having myself taken them for the express purpose of submitting them to this culinary test. If gathered when they are some days old, or in the least degree stale, they have doubtless a certain fishy taste which would prove disagreeable to a refined palate.

The black-headed gull (larus ridibundus) still breeds in immense numbers on some of the marshy islands which are situated among the inland lakes of Scotland and the eastern counties of England. During winter it frequents the flat shores of the coast, especially near the mouths of great rivers, but on the return of spring invariably revisits its usual inland haunts. In former days, when the young of these birds, as well as their eggs, were considered a delicacy, a preserve of this kind was said to have produced a rent of from 50l. to $80 l$. a year. The latter are still highly prized, as would appear from an account of the gullery at Scoulton, in Norfolk, by the Rev. R. Lubbock, who says that "the swampy island upon which they breed occupies a great portion of the mere, and the gulls are indeed in myriads upon it. The worthy proprietor does 
not suffer them to be unfairly molested. A portion of the eggs is always taken; and their numbers may be judged of from the fact that an average season produces more than 30,000 eggs. Five years back the keeper said they took 44,000 . Parts of their abode are so swampy that no one can walk there to gather eggs, which of course tends to the maintenance of their numbers. Now and then a year of jubilee is given, and no eggs taken; this was done lately at the instance of the neighbouring farmers, who justly value the serrices of these birds in the destruction of grubs."

The gannet (sula bassana) breeds in considerable numbers on Ailsa Craig, and on certain parts of the west and south-west coast of Ireland. On the Bass rock, at the entrance to the Frith of Forth, their nests are mercilessly plundered erery year of the young, in a partially fledged state, from the sale of whose down and feathers, as well as of their bodies, the person who rents this isolated cliff reaps a tolerable rerenue: he has thus the power - and exercises it - of preventing parties of Leith gumers from anchoring under the precipice and expending their ammunition on the old ones; but when we recollect that the gannet hatches but one egg, that each pair of adults has therefore but a single young one, and that great numbers of immature birds are 
taken from this spot every year, and even find their way into the Edinburgh market, where they are said to be highly prized by certain epicures of modern Athens-while at the same time the tenant can afford to pay a high rent for his privilege-it is obvious that the casualties to which this species is liable at other seasons of the year must be comparatively trifling, or that the natural laws which govern its general increase and diminution must be very different from those which influence the various families of the gallinaceous order.

The eggs of the guillemot (uria troile) and razorbill (alca torda) constitute an important article of traffic on various parts of the British coast, where the lofty precipices, on the narrow ledges of which these birds deposit their eggs, are constantly explored during the month of May and the early part of June by adventurous cragsmen who have been inured from their boyhood to this dangerous art. Mr. Waterton, in the first series of his 'Essays on Natural History,' has given a graphic description of such a scene, in which he was himself a principal actor, on the cliffs which extend from Flamborough Head as far as the bay of Filey on the Yorkshire coast.

Many members of the great family of anatide (ducks, geese and swans) which used to frequent 
the British shores-especially the remoter parts of Scotland-during the season of incubation, have now become exceedingly scarce at that period of the year even in localities apparently well adapted to their habits. The high value attached to the eggs of the rarer species, as cabinet specimens, has mainly contributed to this result, for the vast quantities thiat appear in the London markets during the winter months-which are mainly supplied from the decoys of Holland, or from the now declining establishments of a similar kind in our own country - have nearly all passed the preceding summer in the boundless morasses of Scandinavia or of eastern Europe. But perhaps of all birds that have been doomed to contribute to the comforts or luxuries of man, without at the same time paying the penalty of death, the eider duck (somateria mollissima) is the most remarkable, and its history the most interesting. The eider is to the native of Shetland and to some of the remoter islands farther north, what the reindeer is to the Laplander, and the seal to the Greenland fisherman, supplying him at once with food and raiment. It has been found in the highest latitudes yet discovered by man, both in Europe and America, and is abundant on the coast of Greenland, and on certain islands on the western shores of Norway, where the birds 
and their nests are strictly preserved. The state of Maine would appear to be its most southern limit in America during the breeding season, and the Fern Islands in Great Britain-in the latter situation however its numbers have sadly decreased-but it must be regarded as only a rare and accidental winter visitor to other parts of England. It is singular enough that in all these countries, although so remote from each other, the value of the down as an article of clothing and commerce, and of the eggs as food, should be equally well known to the natives. The eider belongs to the marine division of the anatida, in which section we find a form more adapted for diving than for rapid flight or terrestrial progression. The legs are larger than in the true ducks, and placed farther back, the webs are wider, the toes longer, and the hind one furnished with a lobe; and the keel of the sternum, or breastbone, is comparatively of but little depth; while the food consists of slugs, insects, and mollusca, and is not of a vegetable nature, like that of the teal, wigeon and mallard.

The male eider is a handsome bird, nearly as large as a goose, his colours black and white, with a large patch of light pea green on the upper portion of each side of lis neck: the female is somewhat smaller and clad in more homely attire. 
her plumage presenting a quaker-like mixture of different shades of brown and grey. Her nest, which is usually in an exposed situation, is composed of coarse marine grass, seaweed, or bent, and is invariably lined with a considerable quantity of fine elastic down, which she plucks from her breast, and in which the eggs, four and sometimes five in number, are more than half concealed. It is even said that she will persevere in this operation and continue to lay after both eggs and down have been removed, and that when her bosom has been at last quite denuded, her faithful partner will contribute to the stock by drawing largely on the resources of his own warm waistcoat, as long as a single egg remains in the nest. Like every other rare and important article of commerce, it is apt to be adulterated, and is frequently mixed with that of gulls, puffins, and divers, by which its value is greatly deteriorated, but the genuine eider-down is so fine and almost impalpable, until pressed together, that, according to Pemant, a quantity sufficient to fill a hat will weigh no more than three quarters of an ounce, and another authority (Wilson) states that although three pounds weight may be compressed into the size of a man's fist, yet such are its elastic powers, that when shaken out it will expand so as to fill a quilt five feet square. 
Although so wary and difficult of approach when occasionally met with in the winter by the wildfowl shooter, yet the tameness of the eider during incubation is so great that it will frequently suffer itself to be lifted off the nest, and in certain parts of Greenland, Spitzbergen, and Icclanci, these are so crowded together that it is difficult for the intruder to avoid crushing their contents under his feet. The birds however would appear to be conscious of their value to man: incleed in ccrtain situations they have been known to select the ruins of old buildings as the site of their domiciles; and althongh in all those parts of the temperate and frigid zones where they are established during the breeding season, it systematic plunder is carried on every day, yet they appear to be under no apprehension for their personal safety. The fable of the goose that laid the golden eggs would indeed be realized if the bird itsclf were to be killed; but the natives are wiser in their generation than the clown in Esop; for it is a singular fact that the down on the breast of a dead eider almost instantly loses its elasticity and value.

But the traffic in eggs, as an article of food, is after all limited to comparatively few kinds of birds. The high price which is given by amateur collectors lias tended far more to reduce the num- 
ber of some of the rarest; the anxiety to obtain such curiosities, and the local temptations to procure them at all hazards, being of course in the same ratio as the scarcity of the species.

Besides the active trade carried on in this line by purveyors from France and Holland; even in Orkney and Shetland, and the remote parts of Scotland, the value of the eggs of the golden and of the sea eagle are so well known to shepherds and keepers that there is every probability of these noble birds-especially the former, whose eyrie is generally on inland cliffs-being more effectually extirpated from this cause than from any other. Although a recent specimen of 'the king of the birds' would always prove a welcome acquisition to a museum, yet ignorance of the art of taxidermy in these distant places, the difficulty of preserving the body untainted in the flesh until a moment of leisure, the probability of its being too much lacerated by a successful shot to admit of even a rude process being carried into effect, and the chance of its falling orer the cliffs and being irretrievably lost; all combine to render these worthies less anxious to destroy the birds themselves than to obtain their eggs, which are easily blown, are comparatively portable, and have lately become in such request that they fetch, on the spot, from a pound to thirty shillings 
each; indeed I have known a larger sum given for a very ambiguous looking specimen in England, 'warranted from the golden eagle,' but which to an experienced eye had an unmistakeable look of having emanated from a Norfolk turkey-yard.

The peregrine falcon, the osprey, the kite, the black-throated diver, and many others come under the same category; their eggs are sought after with the greatest avidity, and the price asked and frequently given for them would be almost incredible if it were not well authenticated.

To a similar cause probably, as well as to its large size and the exposed situation of its nest, the bustard owes its now almost total extinction in England. In Norfolk, which was, or is, its last stronghold, the egg has for many years been worth a guinea to him who was fortunate enough to find it. As a natural consequence of this state of things a set of itinerant charlatans have for some time, and too frequently with success, driven a thriving business by selling counterfeit specimens of this and of almost every other valuable species of egg. The deception is frequently so perfect as to take in many an honest dealer who heretofore flattered himself that he was 'up to' all the 'tricks of the trade,' and who would himself have scorned to foist them in retail upon his own customers. 'The great similarity which the eggs of 
many congenerous birds bear to each other, especially in the wading and swimming divisions, and at the same time the remarkable variety in the superficial markings which even those taken from the same nest frequently present, has suggested one simple and easy mode of deception. Thus, for example, an egg of the great black-backed gull (larus marinus), differing perhaps slightly in colour from the more usual type, will be labelled 'Glaucous Gull' in the travelling boxes of these crafty pedlars; that of the common tern, 'Gullbilled tern,' or 'Roseate tern;' a snipe's egg of unusual dimensions will figure as belonging to the 'Great, or Solitary Snipe,' while a diminutive example of that of the landrail will be inscribed 'Spotted Crake,' or 'Baillon's Crake,' \&c.

But the art is carried to a still higher pitch of refinement. The exterior coat of many of the conmoner eggs-among which those of the goose and turkey play a conspicuous part-is first removed by some chemical process. The new surface is then stained of an appropriate ground tint, and an elaborate and cunningly devised tracery, exactly resembling the blotches and lanifications on the egr which it is intended to represent, is painted upon it, in some adhesive body colour, which when complete, and coming from the hands of a finished professor, would not only pass muster 
in the cabinets of the generality of amateurs, but might deceive eren the most learned of our scientific oologists.

It would appear that feathered game, and indeed gallinaceous birds of all kinds, are exposed to more formidable foes than the members of any other order in this class of animated beings, and require legal protection and care in a greater or less degrec, not merely to ensure their increase, but eren to prevent their extinetion.* Occupying the same station (rasores) among birds, as do cattle (ruminantia) among quadrupeds, their considerable size and comparatively defenceless structure render them an acceptable feast and an easy prey to their numerous enemies.

The nests of the red grouse and indeed eren of the ptarmigan, suffer from the attacks of a feathered plunderer, whose depredations on the heaths and mountains, it must be confessed, far exceed those of any other. This is the hooded crow (corvus cornix). When we recollect the nature of the country that these birds frequent, their immense numbers, the facility with which

* This has once occurred with the capereajllie in Scotland, where it was strictly jndigenous; and who ean doubt that the pheasant-an exotic-would erentually share the same fate in England, if the game laws, deficient and unsatisfactory as they are, were to be repealed. 
the nests of moor-game can be detected by even a less cumning and quick-sighted forager-to say nothing of their own domestic establishments being often in the immediate vicinity, with a hungry family crying for food-it is only marvellous how the grouse continues to survive on certain unpreserved maritime tracts of Scotland and Ireland. Compared with this crow, the eagle, the buzzard, even the peregrine falcon herself are almost innocent and at least honourable enemies; nay eren the fox is harmless when measured by the same standard. I speak from experience. After an absence of several years I found myself, during the autumn of 1848, among some of the wildest mountains of Mayo. There first in early boyhood I loved to gaze at the eagle as he soared among the clouds, or peeped with thrilling interest orer the stupendous precipices peopled with myriads of water-birds, whose discordant cries mingled with the roar of the Atlantic. There first I learned to climb the heathery hill, to point the gun, or mark down the dusky pack under the guidance of my Highland preceptor, and enjoyed many a day's grouse shooting-to say nothing of hares and woodcocks-that might not have disgraced Caledonia herself. Well, the eagle was still there; so was my old friend the peregrine; their ancient eyries were still occupied 




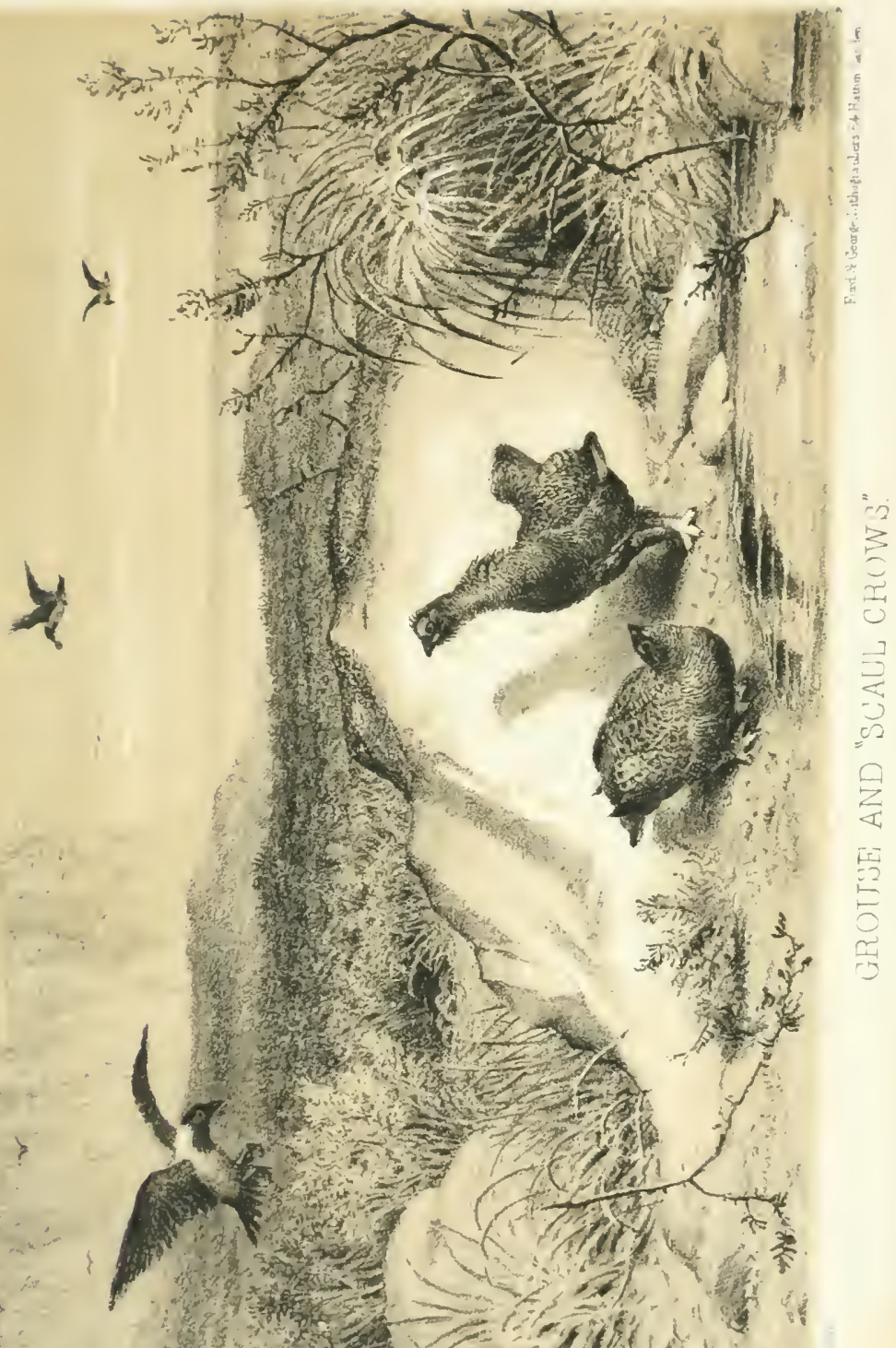

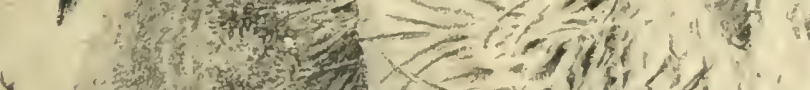

\}$^{40}$
2
2

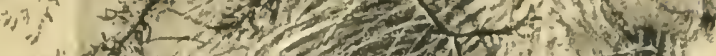

$\rightarrow+2$ 

cither by the same birds or their descendants, and no rival stronghold had becn established on the cliffs; even the fox had not materially increased - as I learned from the best authority, the wives of the poor squatters who were quartered on the outskirts of this wild region, and whose whole wealth consisted of their pig and their poultrybut the grouse were sadly reduced; in fact they had almost disappeared, and in their place vast numbers of the hooded crow were scattered over the face of the country. Not a turf-stack or projecting rock but was occupied by groups of these banditti-looking birds, not a clod or tussock even partially elevated above the heath but one of them was perched on the summit; vigilant, wary, and shy, as if ever on the watch to escape the punishment due to his misdeeds. With his nest securely lodged on the inaccessible shelves of the precipices, he laughs at open warfare, and it is only by stratagem that man can be a match for him. In former times you might have traversed these mountains for an entire day without seeing a dozen 'scaul crows;' the trap, artfully set in the mock nest of a grouse and baited with the egg of a gull or any other bird, was an infallible device; or the shell, emptied of its contents, and filled with melted fat and nux vomica was too strong a temptation to be resisted, and thus the 
numbers of this prolific and really mischievous crow-for he occasionally varies his sport by digging out the eyes of young lambs - were kept within due limits.**

In many parts of Scotland and the north of England, the blackcock and the partridge also suffer from his depredations, but in the central and southern portions of the island, he is fortunately only a winter visitor, although in an open country where extensive downs and flat table-land prevail, with wide fields and stone fences, the partridge certainly finds a dangerous neighbour in the magpie, to whose malpractices such districts are peculiarly favourable; nevertheless, his arch-enemy is the human poacher, and there is no period throughout the whole year when so much injury is done to this bird and to the pheasant as during the early laying season. Keepers are wont to attribute all robberies of this kind to what they call 'vermin,' winged or four-footed, and accordingly wage an implacable war against every bird and

* Mr. St. John, in his ' Field Notes and Tour in Sutherland, says that even the osprey during nidifieation is elosely watched by the hooded crows and the nest frequently plundered in the absence of the female; and lie remarks, with true sportsmanlike feeling, "The hooded erow is the only bird against whom I wage constant and unpitying warfare. I lave so often detected them destroying my most favourite birds and their ergs that I have no pity on them." 
quadruped which is not included in the gamelist. It cannot be denied that the guilty suffer on these occasions as well as the imnocent, and where the intention of the proprietor is to raise an unnaturally large head of pheasants, the destruction of magpies and carrion crows, as well as of stoats and weasels, will tend to promote that object: but therc are one or two points of importance which seem to have escaped the attention of these gentlemen and their myrmidons, in the neglect of which they "strain at the gnat and swallow the camel.' In the first place, while it is freely admitted that a predilection for newlaid egrgs-the natural food at this season of some animals which have been placed by Proviclence as a check upon the excessive increase of otherswill cause many an overt act of petty larceny on the part of certain feathered bipeds, yet it is to man himself that the most serious and wholesale depredations, at this time of the year, are to be attributed. Of all the varieties of the genus poacher-and their name is legion-the eggstealer is at once the meanest as well as the most mischicrous and difficult to detect. Without a spark of the mere brute courage that animates the night-shooter, or the skill, and talent for evading discovery, which characterize the successful wirer or trapper, he possesses not a single 
redeeming quality, and can have no claim whatever on the sympathies of even the most tenderhearted philanthropist. That his trade is a profitable one there can be no doubt: the high price asked and given for pheasants' eggs by London dealers and their customers, is sufficient testimony on this point. The modern rage for the battue has mainly contributed to the success of this degrading traffic. The comparative facility with which a head of pheasants may be 'got up' now-a-days in some suburban grove, by having the eggs hatched under barn-door hens, and the chicks reared in a state of partial domestication, long after they are able to fly, has induced many a worthy citizen, who would blush at the idea of being the second-hand receiver of stolen goods, to give an indirect encouragement to this branch of crime. The pheasant is by no means fastidious about his quarters so long as his daily rations are liberally supplied: he will make himself as much at home in a close shrubbery of laurels and lilacs as in the wildest holt. It signifies not that the plantation be of small extent, or eren destitute of ground cover or brushwood; he is the most accommodating bird in all these matters, and modern invention has supplied a cheap and simple substitutc. So long as the place is fenced and undisturbed, the rest is easy. $\Lambda$ few wag- 
gon loads of faggots, deposited here and there in the copse, aflord a ready shelter for the more timid birds, who betake themselves at once to this retreat at the first alarm from the approaching beaters, while a large heap at the farthest corner serves as a temporary asylum to the main body, and furnishes a grand finale to the host and his gunner guests, who thus acquire a better appetite for their turtle and turbot in the afternoon, than a knowledge of fair play or real British sport in the morning.

But to return. It cannot be denied that during the laying season game-birds require at least as much attention as is paid to them at other times of the year; and it would not be difficult to show that an increased share of activity and vigilance is then necessary on the part of their protectors. It is true that Nature, ever kind, has clothed the hen pheasant in a homely garb, which in many an instance enables her to elude observation, and thus renders her better scrvice than a coat of mail under similar circumstances; but the practised thief has no occasion to search for pheasants' nests. The eggs are usually deposited in rank grass on the sides of hedges and ditclics, in narrow plantations, or in meadows, clover, or corn-fields; and very rarely in the heart of great woods or covers, to which 
localities the keeper is generally too apt to confine his attention. When suddenly disturbed, the hen will sometimes rise at once, as she would if leaving the nest voluntarily in search of food, and thus expose her treasure to the eyes of any wandering clown who may have unintentionally stumbled on the spot; but more frequently she has recourse to artifice, and on the approach of danger quiettly slips off her eggs, and runs with a noiseless pace for a considerable distance before she takes wing. On returning to the nest, however, she adopts a different manœuvre, and if her only enemies were of that class usually denominated vermin, it would almost invariably be attended with success. She continues on the wing until she arrives immediately over the nest, and then drops at once upon it, thus leaving no beaten track through the long grass by which the indefatigable stoat or the prowling cat could find a ready clue to her citadel, or which would at once catch the eye of the cumning magpie or the hungry crow while sailing over the field on a foraging expedition. With the poacher, however, the case is different. He has only to secrete himself under a tree or, it may be, to sit leisurely on a neighbouring stile, immediately after feeding time in the carly morning or in the afternoon, and watch the female bird as she returns to the 
ficlds in the vicinity of the preserves. He fixes his eye on her as she comes skimming orer the hedge and marks the exact spot where she drops among the weeds, grass, or clover. If this should happen not to be in the middle of the field, and if anxious to secure his prize immediately, he walks round with apparent unconcern-keeping close to the hedge all the time, and never once taking his eyes from the spot-until he arrives at the point nearest to the nest, and then stepping up quickly, bags the eggs as expeditiously as possible: but should he think that his tactics have been observed or his intentions suspected, he coolly 'takes an observation' by means of trees, or any other prominent objects, and accurately marking their relative bearing to the situation of the nest, he is then at leisure either to watch for a fresh arrival in the same quarter, or to pursue his avocation in a different direction until the shades of evening enable him to complete his work in security.

Against such wholesale depredations nothing can effectually contend but a shrewd and intelligent keeper, aided by honest and vigilant assistants; yet it is at this season that most preservers are in the habit of clismissing many experienced persons, who have been in constant employment as watchers during the autumnal and winter 
months, when their services were comparatively of little value. Considerable expense is frequently incurred, and much pains taken, in endeavouring to detect the night-shooter who confines his attention to the birds themselves, and who, even with every chance in his favour, can only secure his plunder in detail-and many accidental circumstances may lead to his discovery and punishment -while great facilities are blindly afforded to the sneaking miscreant who plies his trade during the season of incubation, and carries off with provoking impunity a future family of pheasants or partridges in the bottom of his pocket or in the cromn of his hat.

Again, to say nothing of his senseless and cold-blooded persecution of many innocent birds at this time of year-such as the woodpecker, the cuckoo, and the nightjar-the keeper is too apt to rely on his gun alone for the destruction of those which are the natural enemies of game, as well as of others whose depredations in that way are but partial, but whose character may nevertheless have been compromised by an occasional peccadillo. Accordingly, the fowling-piece is seldom out of his hands during the breeding season. Instead of showing himself on the outskirts of his beat at irregular periods and when least expected, after having risited his traps in 
the early grey of the morning, he spends the greater part of the day in the covers and plantations, blazing away at the unfortunate squirrels - as in all the energy of carly May, and little anticipating their fate, they bound joyously from spray to spray among the spreading branches of the oak-or cunningly imitating the call-note of the merry jay - an accomplishment, by the way, on which the young aspirant especially prides himself, and to the acquisition of which he devotes a considerable portion of his time-he attracts numbers of this social bird to his place of concealment and shoots them without remorse; thus at once assisting in the extermination of a beautiful and now rapidly diminishing species, alarming the game and driving it either into a neighbouring preserve, or still worse, perhaps to an adjoining waste land or common-the territory of the gypsy and the tramper-and proclaiming his own whereabouts to the surrounding population of evildoers.

I have no wish to enter on an indiscriminate defence of all my feathered favourites, or to shut my cyes wilfully to the miscleects of the carrion crow, or the magpie. Their predilection for eggs is undeniable; it is strongly implanted in them by nature, and amply do they suffer for the indulgence of this inherent propensity: but I firmly 
believe that one 'unplumed biped' * of a poacher, possessing a moderate share of experience, and in the unrestricted exercise of his calling, will purloin a greater number of pheasants' eggs from a preserve in a couple of days than all the unhappy members of the genus corvus which the keeper may shoot during an entire summer. Indeed, a familiarity with firearms, except as regards the art of cleaning his master's gun, is perhaps the very last accomplishment that a gamekeeper need possess. The trap is the peculiar implement of his calling. An acquaintance with the nature and habits of those animals that are really detrimental to the objects of his careand for which he possesses so many facilities-will enable him to adopt the most direct and effectual modes of capturing them. He will discorer-for the truth must be told-that the abstraction of eggs from that pheasant's nest, so snugly, and, as he fondly imagined, so securely concealed under a thick canopy of fern, and fenced with impenetrable briars, was not the work of the poor jay, or even of the ragrant crow, or the roring magpic, but of the hypocritical hedgehog, the most insatiable of all ovivorous Britisl 1 quadrupeds-whatever his well-meaning and amiable

* "Animal bipes implume,"-Plato's definition of man. 
defenders may say to the contrary. He will learn that hawks do not meddle with eggs, and that the mother-bird, during the process of incubation, is secure from the attacks of the smaller falconidce. The popular errors of his craft and the fables of local tradition will be gradually exposed to him as he prosecutes his inquiries and learns to judge for himself. He will read in the book of Nature, and without having recourse to the pages of Aristotle, that the cuckoo is never metamorphosed into a hawk; that the barn-owl never trespasses on his territory, and is besides the most efficient of mousers; that the services of eren the wood-owl amply atone for his oceasional misdemeanours, and that the sparrowhawk and kestrel are birds of widely different habits, and deserving of very opposite treatment at his hands: he will learn to distinguish the guilty from the innocent; to punish the former and to spare the latter; and instead of being a noisy and blundering persecutor of many harmless and even useful animals, he will become a valuable servant to his employer, and a rational member of the community. 


\section{CHAPTER XII.}

"Those fenceless fields the sons of wealth divide,
And e'en the bare worn common is denied."

GOLDSMITH.

The Capercaillie - Charneteristic Habits - Nature of the Country suited to it-Unsuccessful Attempts to Naturalize it in England-Restoration of the Capercaillie to Scotland - Mode of Management and Propagation Present Condition of Capereaillie at Taymouth - The Black Grouse-Its introduction into Ireland desirableNatural facilities for its establishment there-Obstacles to its Increase in England-Plan recommended-Diffculties to be surmounted-Unity of Interest and Mutual Adrantage.

THE noble capercaillie, or cock of the wood (tetrao urogallus), after having disappeared from the Scottish forests about sixty years ago, has now been restored through the spirited exertions of a few large landed proprietors, among whom Lord Breadalbane stands preeminent.

The successful establishment of the pheasant in England, though a native of the distant shores of the Caspian sea and even of the yet more remote regions of Cathay, might appear to en- 
courage the hope that a similar attempt would, under eertain restrictions, prove equally so with the great game bird of the North. But the wild and roving habits of the capercaillie are less favourable to naturalization in the highly cultivated districts of England than those of the comparatively docile Colchican. The capercaillie is essentially a forester. He shuns the open plain, and scorns such a limited range as could be provicled by any artificial plantations for which the heaths and commons of the southern parts of England might be adapted, while in the pinewoods, and extensive tracts of the Highland forests he can yet find space to roam comparatively at large. Even the craggy mountains of North Wales would not appear to offer him a favourable resting place, for though their wild grandeur and lofty peaks would seem to have tempted the ptarmigan-so peculiarly a mountaineer in his habits - yet from some cause, as yet imperfectly understood, this nember of the grouse family seems to have abandoned the Welsh hills; and even their loftiest eminences, being so bleak and destitute of trees, would fail to attract the capercaillie. Nevertheless, as numerous wide-spreading plantations of larch and fir have of late years been formed on the hill sides, in some of the larger estates of Caer- 
narronshire, Merionethshire, \&c., it is not perhaps too much to hope that they may be tenanted in some future day by the gigantic Norwegian.

Some English proprietors have indeed attempted the introduction of the cock of the wood - but ineffectually. So many circumstances must combine to conduct the experiment to a happy issue, that the absence or failure of any of these conditions has in sereral cases led to disappointment of the most sanguine expectations. One of the most essential requisites however, and that which is absolutely the 'sine qua non,' is a vast range of pine forest: a moderate, or even a wide, extent of moor and heath, though interspersed with large plantations, is insufficient for the bold range of the capercaillie. He is not to be restrained within ordinary boundaries, but soon wanders beyond the circuit of any limited protection; when his large size, comparatively defenceless habits, and tempting singularity of appearance, expose him to many casualties, ${ }^{*}$ and

* A friend informs me that "in 1842, or in 1843, Mr. Drummond, M.P. of Albury Park, Surrey, turned down six eapereaillie, three eocks and three hens. One coek was killed by a fox the same night that he was turned down, and two hens were shot in the neighbourhood by mistake as unknown birls." 
thus it has but too often happened that the endeavours to establish this species, by the introduction of a few birds of both sexes into a circumscribed territory, have been, by some unlucky disaster, crusled in the outset.

Through the kindness of a relative of Turd Breadalbane, I am enabled to add a few particulars connected with the present state and condition of the capercaillie at Taymouth (July 1850), furnished by the intelligent head keeper, Mr. Guthrie, to whose judicious management their establishment and preservation are in a great measure to be attributed. Ample details of the most approved method of keeping the birds in a state of confinement and of rearing the chicks -nearly similar to that pursued by Mr. Guthrie -are given in Mr. Yarrell's ' History of British Birds'; but Mr. Guthrie found that the treatment of the chicks, after the eggs had been hatched under domestic hens, was attended with much more difficulty than in the case of the pheasant. Experience showed him that it was necessary to move the coops to different parts of the forest according to the state of the weather; placing them, on a sunny day, under the shadow of trees or among tall grass or fern; but during damp or wet weather removing them to dry, bare, or sandy spots. While transporting them from 
one place to another he "put the chicks into a small woollen bag, and the hen into a basket covered with a cloth to keep her in the dark." When a fortnight or three weeks had elapsed he did not think it necessary to move the coops. He remarks, "After a time I gave the young birds very little food out of hand, except wild berries, and as soon as $I$ got them to feed on the larch branches, I considered them safe. The Scotch fir is rather hard for their bills when young."

In 1838 and 1839, Lord Breadalbane received from Norway fifty-four adult capercaillie: about two-thirds of which were females. Some of them were liberated in the forest, and others kept in a large aviary for the purpose of procuring the eggs. The plan of placing these in the nests of grey hens, subsequently pursued by Mr. Guthrie, proved eminently successful. The birds have steadily increased of late years, and now " all the old woods about Taymouth Castle are full of capercaillie, such as Drummond Hill, Kenmore Hill, Croftmorraig Hill, \&c. Several migrate every season down to Strath Tay, Blair Athol, Dunkeld and the woods about Crieff;" so that the truly noble enterprise originally undertaken by Lord Breadalbane has been crowned with perfect success, and the king of the game birds may 
now be said to be restored to his hereditary dominions.

'The black grouse or black game (tetrao tetrix) is firmly established in Scotland and the north of England. It belongs to the restricted genus tetrao, of which this and the capercaillic are the only two representatives in the British islands; the red grouse and the ptarmigan having been placed in a separate genus (lagopus*) from the peculiar nature of the foot, which is entirely covered with short thick plumage.

In many respects the black cock would appear to occupy a station intermediate between the red grouse and the pheasant. Like the former it is partial to the heather and the moors, but prefers the lower valleys and the neighbourhood of water and wood to the higher brows of the mountains; and although the tarsi are covered anteriorly and on the sides with short feathers, yet the toes are naked, and the external margins of each are furnished with a series of short, comb-like teeth, directed outwards, while the soles are remarkably soft and elastic-a peculiar conformation which is still more distinctly developed in the capercaillie, and which is admirably adapted for enabling him to preserve a firm footing on the slippery boughs

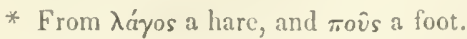


of the fir trees, during the severe storms and protracted frosts of a Scandinarian winter.

Again, unlike the red grouse, the black cock is polygamous, as the pheasant is, and, in common with all birds that evince similar Mahomedan propensities, the adult male is larger than the female, and clothed with a shining metallic plumage, while the latter is attired in a homely suit of brown and grey, rendered nevertheless exceedingly pleasing to the eye by the beautiful arrangement of its tints and their occasional admixture with transverse bars of black and white.

Extensive moors and swamps, with glens of birch or covers of spruce or Scotch fir, are his farourite haunts, while the harly nature of the bird, and his shy and wary habits during the winter and spring months, have tended to prolong his existence in many counties where eren for ages he has been but thinly distributed.

It is to be hoped that when better days dawn upon the landed interest in Ireland, the introduction of the black grouse will not be forgotten, and that the trial will be made upon a larger scale, and upon a better system than has yet been attempted. A few enterprising sportsmen have indeed occasionally endearoured to lead the way in this undertaking, but their isolated efforts have hitherto proved unsuccess- 
ful : and yet how great are the natural facilities for the establishment of black game in that country! Vast tracts of heather-clad, boggy mountains require nothing but plantations of birch, hazel, willows or alder among their lower glens, to render them everytling that could be desired in a natural point of riew, yet at this moment not an individual of the species, I believe, exists in a wild state throughout the entire island.

There have been many and more successful attempts there of late years to encourage the pheasant, as a park or shrubbery offers a field sufficiently large for the experiment on a small scale, whereas with black game a tract of mountain, bog, or moor in combination with wood, is necessary. Yet the former is, strictly speaking, an exotic, and a wet climate is peculiarly unsuited to him. The latter on the contrary requires a swampy soil, and a sufficient extent of quick growing cover might be easily raised for him among the mountain valleys, while large woods or forests of timber trees are more necessary for the permanent establishment of the pheasant. Again, the black grouse would soon possess that invaluable charm of which the pheasant could never boast, that of being strictly fera naturâ in those wild and thinly inhabited regions-a meet companion for the moor fowl and the woodcock-ancl 
how many causes, social and political as well as natural, must tend to retard the increase of the pheasant in that country! Besides the dampness of the climate and the scarcity of timber, the great amount of population in the cultivated districts, and the general disregard of all legal restrictions, are far more serious obstacles; and although from its very rarity it is well suited as an ornament to the park or pleasure grounds of a nobleman or country gentleman, and may even serve, as a last resource, to relieve the dulness of 'a blank day,' yet as an old woodcock and snipe shooter, I, for one, should be sorry to see it occupying too large a share of the attention of the Irish sportsman.

On some of the well-wooded and extensive estates in Wales, Scotland, and the north-east of England, the pheasant has certainly been on the increase of late years; and among the birchen glens and moors, affords, together with black game, a delightful combination of sport which the southern shooter must generally sigh for in vain. It is true that black grouse are still to be found in a few lighly favoured spots in Devonshire, Dorsetshire, Hampshire and Sussex-and even there, the privileged sportsman who is permitted to take the field can seldom depend on bagging more than a brace or two after the first fortnight 
of the season-but I have not been able to learn that their numbers are augmented, as they might be, by either of the two modes usually adopted for the increase of pheasants-riz., frequent importations of fresh birds from a distance, or having the eggs hatched and reared under domestic hens, and the poults subsequently turned down. It may be objected that the first of these modes is attended with considerable expense, and that the latter requires too much trouble, care, and attention, to ensure its general adoption: but it has often occurred to me that another, and very different, plan might be tried with advantage, and would be the more likely to prove successful because it would require but little interference on the part of man, and almost the entire proceeding might be safely left to the guidance of Nature lierself.

The idea first struck me when conversing some years ago with a Scotch landed proprietor, who told me that he had introcluced the pheasant among his black grouse by placing the eggs which had been previously laid in an aviary in the nests of grey hens.* One or two only were put into each nest, in which about half the usual comple-

* The reader will have observed that the same system has since been sucessfully adopted at Taymouth with the caper- 
ment had already been deposited by the rightful owner. This was done during the temporary absence of the female bird. The young pheasants grew up with their foster brothers, partaking of the same insect food, and showing a similar predilection for nost kinds of berries and certain bulbous and tuberous roots during the latter part of the summer; and although disregarding the tender shoots of the heather and bog myrtle, which the black grouse deroured with aridity, yet erincing of course a strong partiality for the corn fields during the autumn, and for all kinds of cereal grain, in which their sable friends were ever ready to participate at the same season.

It must be admitted that the chief obstacle to the existence or increase of the black grouse in the south of England is the genius of modern agriculture. The rage for enclosing and draining waste lands and commons-where the soil, frequently sandy and poor, can never repay the first outlay of the wealthy experimentalist or the subsequent labour of the husbandman-has expelled it from many districts where it was of frequent occurrence, even within the memory of the present generation. But besides the ancient forest moors, there are still sereral extensive heaths-as for example, in West Sussex 
-which, from their peculiar situation and the present depreciated state of all farming produce, are not likely, at least for many years, to be absorbed in the surrounding tillage. Many of these are intersected by clear streams, and broken here and there with clumps and plantations of alder, birch, hollies and fir trees, and adjoin, or are included in, the manorial rights of extensive neighbouring preserves. Pheasants, partridges, a few snipes, and even woodcocks, are found during different periods of the shooting season; but the black grouse is unknown. Doubtless he was here the representative of the tetraonide in former days, but the very memory of his existence has since faded away. Now, reasoning from analogy, it has often struck me that he might without much difficulty be restored or introduced into these beautiful wastes by simply reversing the process that has already -in the case to which I have alluded-proved successful in the North with the pheasant. The food of the two species, if not identical, is yet sufficiently alike to render any objection on that score unreasonable. The eggs are nearly of the same size, and require about the same period for incubation. Both birds are polygamous, and so far from evineing any hostility to each other, there are numerous instances of hybrids having 
been produced between them.* The moors of which I speak abound in plants which furnish the favourite food of black game, such as whortleberries, bog myrtles, heather, dwarf willows, young Scotch firs and birches; and besides the ample autumnal gleaning provided by the neighbouring cornfields, the same barley-stack that the keeper now raises for his pheasants in the plantations, would prove equally attractire to the northern emigrant during the winter season. Indeed there seems to be but one important though, I trust, not insuperable obstacle. Estates in the south of England, however extensive, are seldom included in 'a ring fence.' Many a little tongue of moorland, or corer, or arable ground, protrudes its unwelcome presence into the preserves of the large landed proprietor, and proves a thom in the side of himself and his gamekeepers. These frequently belong to persons in the middle class of life, who, although too thrifty or penurious to assist in the maintenance or protection of game, are ever ready

* Mr. Yarrell has recorded thirteen examples, some of which are illustrated by beautiful woodeuts. There is another in the Chichester Musem which prartakes strongly of the character of both parents, and I have seen a rery beautiful specimen at Hollycombe - the residence of Sir Charles Taylor. Bart.-which was shot in Wolmer forest. 
to destroy it: whose guns are never idle. during the shooting season, and whose larder amply repays them for the unavoidable expense of ammunition and a certificate. Such neighbours must prove serious stumbling blocks in the way of introducing any new species of the gallinaccous order of birds, but, as I have already ventured to hope, not insurmountable obstacles. No true sportsman will regret the absence of the isolated, overstocked preserve, if he can see a fair sprinkling of different species of game birds scattered over the face of the country. 'To effect this the sunall proprietor should have a direct interest in the matter, and the tenant must be convinced that that of his landlord is in some degree identical with his own. When this feeling has once been established-but not until then, I fear-will the farmer condescend to become an ornithologist; to listen calmly to reason; to perceive that the partridge and the pheasant are really his friends during nine months out of the twelve, and to admit the injustice of attributing to them the injuries that have been committed on his crops by hares, rats, and rabbits.

But eren as matters stand at present.-If the borderers on the large estates could be made to see that the introduction of the black grouse would eventually tend to increase their own 
share of the sport as soon as it was once firmly established, the experiment might be tried at once. If they would abstain for a few seasons from shooting down any stray poult that might wander into their beats, how amply would they be recompensed for their forbearance! There need be no excuse of mistaking the inmature bird for a young pheasant; still less for a partridge; the shortness of the tail, on the one hand; and on the other, the length of the neckwhich is protruded in flight after the manner of a wild duck - ought to be sufficient to prevent the chance of such a, mishap; and in a few years they might - with due regard to sex venture to pull the trigger without any conscientious scruples, and congratulate themselves on having been instrumental not only in making a most valuable addition to the local list of game birds, but in introducing one of the finest and most palatable species of grouse into their own larders. 


\section{CHAPTER XIII.}

"Not dead! Not yet quite dead?
I that am eruel am yet merciful;
I nould not have thee linger in thy pain."

Othello.

The 'Random Slıot' - Field Sports - Cruelty tempered by Mcrey-Museum Leetures-Maxims for Young Sportsmen-Destruetiveness of a Bad Shot-A Case in Illustration-Retriever over-matehed-Evil Consequenees of Careless Shootirg and Random Shots-The best not infallible-Necessity and Use of a good Retriever-The most promising Breed-Experiments and Observations-Importanee of Diseipline-A Field Day.

Who that has seen it can ever forget the emotions of pity which a contemplation of Landseer's exquisite picture of 'A Random Shot' never fails to produce. Yet how simple are the materials that the great master has called to his aid. Here is an ineident of ordinary oecurrence in the early experience of a thoughtless deer stalker. $A$ hind who has received her death wound from a rifle that was perhaps hastily discharged at one of the antlered lords of the herd, lies dead upon the snow. She has apparently strained every nerve 
to continue her retreat as long as possible, and her deep and bloodstained tracks are visible up to the spot where she has fallen. At her side stands her shivering calf, destined, poor thing, to a certain and lingering death. It has followed its dam to the last, and now, unconscious of the calamity that has befallen her, is vainly endeavouring to extract a drop of nourishment from her rigid carcase. Many and many a sportsman who, as he gazed on this beautiful work, has experienced a pang of remorse, and readily acknowledged its benign influence, is, alas ! too apt to forget in the field the moral lesson which it inculcates, and to prove, by his reckless expenditure of powder and shot in the ensuing season, that other animals besides red deer are doomed to the miseries entailed by a random shot.

It would be useless to deny that all field sports, eren when conducted on the most humane principles, are attended with a certain degree of cruelty, but it is obvious that none should venture to prefer such a charge except those who rigidly, and from conscientious motives, abstain from all kinds of animal food. All other persons afford an indirect encouragement to the deprivation of life, and are as deeply implicated in the culpability as the actual perpetrator of the deed. How unjust, then, to abuse the grouse shooter 
and the angler while we encourage the poutterer and the fishmonger, or to condemn the deerstalker while we patronize the buteher.

An instinctive love of the chace seems to be innate in man. It prevails equally amongst the most barbarous savage tribes and the most enlightened cultivated nations, and exists as strongly at the present moment as in the days of Nimrod. But while, on the one hand, the maudlin complaints of modern sentimentalists may be treated with contempt or derision; on the other, it must not be forgotten that 'the quality of mercy' is the noblest attribute of the 'true sportsman,' an appellation of which the mere bird murderer and the cold-blooded pot-hunter are utterly unwortly, while even the well meaning but thoughtless gunner who indulges in a long range-where game is sufficiently plenty to admit of his picking out his birds within a moderate distance and 'killing them clean' - must abandon the cruel though occasionally tempting custom before he can justly lay claim to the title.

I an aware that it is easier to preach than to practise, and readily admit that ' in my hot youth' I was no better than my neighbours; but the very recollection of these jurenile delinquencies renders me now the inore anxious to make some 
amends by endeavouring to dissuade others from a habit so mischierous yet so easily corrected. With this view I have occasionally, during the last few years, preserved a specimen of a pheasant or partridge, which at some period prior to its death had been mutilated or disfigured by a random shot, and whenever a youthful visitor to $m y$ museum shows symptoms of sporting propensities by a marked admiration of the game birds, I generally venture to read him a lecture on the subject, and to draw his attention to my assemblage of cripples which I call the 'Chelsea Hospital' of the collection. I also tell him that it is a bad practice to fire at a pheasant the moment it rises from the ground, if it springs within a few yards of him; for the shot not being spread until it reaches a certain point, the bird in all likelihood receives the whole charge or none of it; and the consequence is that it is either woefully mangled or missed altogether. On the other hand, if a bird should rise out of distance, it is essentially wrong to let fly at it on the chance of a stray shot bringing it down; for the probability is very great that, if hit at all, it will only be wounded and lost.

Most of my specimens furnish examples of the former error. There is one miserable looking hen pheasant in particular which never fails to 
attract attention. Her entire beak had been shot away. Indeed, both mandibles and the tongue were gone, leaving a wide aperture, the edges of which, under the healing influence of dame Nature, had hardened into a pair of Lorny lips; and thus the poor bird-unable to procure its usual insect food, or to pick up any scattered grains of corn-was compelled to haunt a small barley stack, near the keeper's house; the sheaves of which being loosely placed together, she contrived to extract the ears separately, and to provide herself with sufficient food, for she was by no means in bad condition when killed by chance at the close of the season.

But the number of birds thus maimed or disabled, are as nothing compared with those which, appearing scarcely to wince under the effects of a long shot, are fated to perish miserably in some remote corner of a wood, unless the fox or the stoat should fortunately discover the spot, and charitably anticipate their wretched end. The anıount of mischief occasionally perpetrated by the norice, who is thoughtlessly permitted to shoot at every thing, bccause he seldom succeeds in bagging a bircl-and is therefore erioncously supposed to commit less havoc than a good shot, is really incalculable. The lord of the manor, if he is himself no sportsman, but merely preserves 
a head of game for the amusement of his friends, will perhaps say to his keeper. "Now, Smith, here are Captain Hawthorn and Lord Tyro going out to-day. You will take them to the hanger, where the tame birds were turned down this year. I don't want more than ten brace killed in that quarter, as I wish to leave a good stock for next year. The Captain is a dead shot. Put him on the hill at the top of the cover; none but old birds will fly that way, and they will run to the end, and perhaps be off before he gets there. So much the better. As to Lord Tyro, he is only a beginner. Place him in the bottom between the hanger and the gorse, where you have the barley stack. Most of the birds will go over his head. $\mathrm{He}$ will have two guns, and you may let him blaze at every thing. I am told he can't touch a feather; but I wish him to have plenty of shooting."-" Very well, sir," says Smith, who perhaps knows his master's temper too well to venture an expostulation, while at the same time an expression of care and anxiety shows that he entertains some doubt as to the prudence of this. arrangement.

Away they go. On arriving at the corer the shooters are placed in their allotted positions, Captain Hawthorn-an old sportsman-soon sees 'how the land lies,' and perceiving that the cocks 
have begun to run at the first movement of the spaniels, he loses no time in getting forward, and stations himself quietly at the end of the copse, where he bags his ten or dozen cock pheasants before the beaters have come up with him. In the meantime, what has Lord Tyro been about? The birds are flying before, across, and over his head, presenting every imaginable variety of shot at easy distances. The kecper-who had entered the cover along with the beaters-now pauses, and leaning over the fence on the lower side of the hanger watches his performance with an anxious courtenance. The gentleman has evidently seen a gun before, for he handles the weapon with an easy familiarity, and brings down his first birdonly winged however-and as it runs across the meadow towards the gorse-field, he secms in doubt for an instant whether to pursuc it, or to take his second gun from his attendant, when a sudden burst of five or six pheasants at some distance settles the question. He is evidently bewildered, and cannot make up his mind which to select until all are nearly out of reach. At last he fires at one-rather a long shot-a slight shudder, unnoticed by him or his man, does not escape the practised eye of the keeper, but the bird continues its flight and drops apparently unhurt into the furze. In the meantime two more bar- 
rels have been discharged with a similar result. A few feathers indeed are floating on the air, which seem to afford some consolation to the unsuccessful gunner, as he turns round exultingly to his loader and cries, "I hit her, John, however." "That you did, my lord, she's a dead bird." "Mark her down, John." "Look out, my lord, there 's another over your head." Bang -bang- "She has left her tail at any rate-confound it-I can't account for it-I made out much better with the pigeons last week-I'm sure the powder must be damp-load away, Jolm." Bang. "There 's one down this time. Where's the retriever?" "Not come back yet, my lord." "D-n the dog, he's not worth a halfpenny-run after her yourself-make haste, she 'll get into the gorse if you don't. Holloa ! stop! come back! you've got the caps and the wadding-" But John is out of hearing, and Lord Tyro having no ammunition in his own pockets, a respite is fortunately afforded, of which Smith, the keeper, promptly arails himself, and makes the best of his time to hurry the beaters and spaniels to the end of the cover for the final 'bouquêt' before the gruns can be reloadedmuch to the mortification of his lordship, who is now rumning at his best speed to the corner of the hanger-and soon afterwards Captain Haw- 
thorn closes the performance with a right and left at two cock pheasants which fall dead at the feet of his less successful companion.

Such a scene as this, if frequently repeated, must be attended with the worst consequences. When a certain number of hens are to be killed for the purpose of replenishing an empty larder, if possible let the blow be struck by a sure hand. It is astonishing how many are annually rendered unproductive, or receive their death wounds from persons who, although fully deserving their reputation of being 'bad shots,' contrive to aim sufficiently straight to send a few grains into almost every bird at which they fire. Where such licence is permitted-nay, even encouraged-how can the proprietor of the manor wonder at the sterility of his hen pheasants next year, or conscientiously lay the blame at the door of his keeper! For my own part I never knew an honest fellow of this sort who did not rejoice to see the birds 'killed clean;' even when the execution was carried on without sufficient regard to the prospects of the ensuing breeding season.

But even fair sportsmen are not all 'dead shots.' The best are not infallible, and, where there is much shooting, a pheasant may now and then not fall at once, or if it falls, may prove 'a runner.' In such cases a good retriever is a 
valuable acquisition, and if the party is large or more especially at a battue, two or three dogs of this description, thoroughly under command and well up to their work, may really be denominated 'angels of mercy.' For the grouse or partridge shooter it is sufficient, nay, even preferable, that his setters should be good fetchers as well as finders - although few are so fortumate as to possess such dogs as unite the double accomplishinent in perfection, or admit of the inculcation of the one without detriment to the other-but for corer-shooting, where a team of spaniels or a party of beaters are employed, a regular retriever is necessary. ${ }^{*}$ There is great diversity of opinion as to the best breed. Most persons prefer the Newfoundland, not only from his docility but from his size and strength, which enable him to carry hares with great ease through the tangled brushwood, and even over gates and fences, which

* In hazarding this opinion I am aware that it is at variance with that of many who lave had more experience in eanine tuition than myself. While on this subject $I$ camnot refrain from eongratulating the sporting world on the appearanec of Colonel Hutchinson's little work on " $\log$ breaking." In all that relates to the training of setters and pointers it fully carrics out the promise on its title page, of presenting "the most expeditious, certain, and easy method." It is indeed a perfect text-book on the subject, and its price, as well as its dimensions, ought to ensure it a place in the preket of every sportsman and gamekeeper. 
rould oppose formidable obstacles to the speedy return of a smaller dog. Others, again, recommend a cross of the sheep dog or setter; while some aldrocate a touch of the greylound or lurcher. I have myself bred, broken, and tried them all during the last ten years, and have besides had many opportunities of witnessing the performances of retricrers of various breeds in the possession of others; and the conclusion at which I have arrived is that a cross between the broadshouldered, short-legged Newfoundland and a thoroughbred setter, is more likely than any other to answer the expectations of the sportsman. Dogs of this description possess the strength, aptness for receiving instruction, and general steadiness of the one, combined with the fine nose, quickness, and accuracy in following on the track of feathered game, which characterize the other. No doubt good retrievers have becn obtained of almost every sort; but this cross affords, in my opinion, the best chance of success where time is an object, and where the puppy -as is too generally the case-is consigned to the care of an indifferent trainer.

My first experiment with the greyhound was the produce of a powerful dog of that kind, and a capital retriever, who was herself the offspring of a Newfoundland and a setter. I kept two 
of the puppies and gave the others to four friends, who were as sanguine as myself in their expectations, and looked forward to bagging every hare that they might happen to wound during the following season. One of my dogs turned out a useful ally in that department; but his power of scent was comparatively back, and he was always apt to overrun his birds. He was also naturally hard-mouthed, and time - which alone will frequently tend to correct this serious fault-seemed in his case rather to aggravate it. It was, moreover, impossible to keep him at heel without a leash when a hare was started. The same faults and propensities-probably derived from their sire*-were developed to a still higher degree in the dogs that I had given to my friends. Their keepers were in despair, and, with the consent of their masters, soon knocked them on the head; as they all agreed that 'though not worth their keep for a gentleman,' they might become dangerous enemies in the hands of a regular poacher. Indeed, the lurcher - which was so much used formerly by persons of that calling, and by whose assistance such great destruction was committed among rabbit warrens-was originally a cross between a greyhound and a sheep dog, * Mr. Youatt-a high authority-says that "whatever be the eross, the greyhound will predominate." 
exhibiting all the speed and love of the chace appertaining to the one, combined with the sagacity and intelligence of the other.**

It is a common practice with keepers to lead the retriever in a leash until the moment when his services are required, and then to liberate him suddenly. This may be necessary where the dog is badly broken. In short, when he cannot be

* The late Sir Thomas Thompson, Bart. R.N. had a dog, the off:pring of a lurcher and a thorouglibred greyhound. He was therefore three parts a greyhomnd, of which he possessed in a high degree the characteristic qualities, together with the cunning and acuteness derived from lis more remote ancestor. In appearance he was like a Seotch deerhound on a small scale. He would walk quietly at heel on a high-road or footpath, but as soon as his master opened a gate, he would instantly start off and make a circuit of the entire field at a slow eanter, keeping his eye all the time on the hedge. If he diseovercd no run, or meuse, he would resume his position behind his owner, who during this time lad been watehing his manœurres from the gate. If on the eontrary the dog had pereeived a run in the fence, he would suddenly eheek his eareer and sit down alongside of it. This was a hint to Sir Thomas to commenee his part of the proceedings, which was nothing more or less than to walk up and down the field until he had started the hare, which, as it cndearoured to escape at the meuse, was generally snapper up by the dog with unerring dexterity. Oecasionally lowerer she would make for a second run which had escaped the previous notice of the greyhound, but before she could carry her intention into effect he would be up and close at her haunches, 'turning' her once or twiec, killing her 'in the open, and funally bringing her to his master to receive the reward of his suecessful exploit. 
kept at heel by a sign or word of command. It has been said, and with truth, of setters and pointers, that they ought to be the constant companions of the person who has the charge of training them, that they should be hunted exclusirely by him, and that therefore, when practicable-that is to say, when he can afford the necessary leisure and at the same time possess the indispensable qualifications of patience and good temper-the sportsman should break his own dogs. This remark applies with still greater force to the case of the retriever. He should never be confined in a leash. He should follow close behind his master or trainer. No temptation should be sufficiently strong to induce him to quit his heels-after he has been once completely broken-without receiving the signal or word of command to do so. But to effect this he must be carefully educated by the same person from an early age, and accustomed to follow without leash or strap.

The most effective retrievers I ever saw are those belonging to a time-honoured friend of mine -a thorough-bred sportsman of the old schooland their merit consists rather in the perfect manner in which they have been trained, and can be hunted by the respective keepers to whose care they were consigned at an early age, than from any facilities or advantages aflorded by the 
breed; for many of them arc, in appearance, short-coated nondescripts, and required far more care and trouble in the training than if some attention had been paid to procuring dogs of purer blood; but this deficioncy is amply counterbalanced by the admirable way in which they are managed. I well remember the first time I ever had an opportunity of witnessing their performance. On arriving at the cover's side-an immense wood in the weald of Sussex-we found the head-kceper already there with the spaniels. A regiment of beaters were drawn up at a little distance, and at intervals in their ranks were five under keepers, who subsequently assisted in maintaining the line of march and preserving discipline. Each of them was attended by his dog, who followed close at his heels, unrestrained by string or leash. As we adranced through the cover, any one of these, at a word from his master, would instantly enact the part of a spaniel, and where a thick bed of black-thorn happened to intervene, which was impenetrable to the beaters, he would work his way through it, and flush a hare or a pheasant, but, without attempting to pursue it, return the next moment at the well-known signal to his former position. When a pheasant was wounded and fell at a distance, the dog would endeavour 
to mark the place if possible, and then look round at his master as if for permission to "go and fetch it.' This, however, was not always granted, for if the spot where it had dropped lay more directly in the line of one of the other keepers on either flank, his dog alone would be despatched in pursuit, and thus the common occurrence of a pheasant being mangled by the joint efforts of two rival retrievers was aroided, and the utmost expedition at the same time attained in bringing the bird to bag. Many a winged pheasant and wounded hare was recovered on that day, which if matters had been conducted upon the ordinary system, must have been infallibly lost. The example indeed is well worthy the imitation of all preservers, and may be strongly recommended to the admirers of the battue, not only for its obvious and easily appreciated effect upon the gamebag, but on the higher principle of mercy and lumanity, as affording a means of rescuing many suffering animals from the tortures of a lingering death. 


\section{CHAPTER XIV.}

\footnotetext{
"Hre tibi erunt artes: pacisque imponere morem, Parcere subjectis, ct debellare superbos."
}

VIRGIL.

Four-footed Vermin-Less Destructive than the Human Poacher-The Fox-Conflicting interests of the Foxhunter and Game-preserver-Wild Cat-Its Predatory Habits and Feroeity - House Cats running Wild-A Retricver Cat-The Marten-The Polecat, Stoat, and Weasel-Utility of the Weasel-Anecdote-The Hedgehog-Derours Eggs-The Mole-Not only Harmless but Beneficial - Witnesses to his Good Character - The Squirrel unjustly Accused-Trial without Jury.

IT must be ackmitted that game of all kinds suffer more from man than from any other sort of 'vermin' winged or fourfooted; nevertheless the human poacher is on the increase, while most of the latter are diminishing or have disappeared: thanks, in a great measure, to the unsatisfactory state of our existing code of protective laws, - the discussion of which, however, is rather the province of the journalist and the legislator than of the naturalist or sportsman. To say nothing, therefore, of the encouragement which the pro- 
fession of poaching has received of late years from the misapplied sympatly of morbid humanity-mongers and the verdict of many a magisterial bench, it may be observed that the decrease of game in many parts of the British islands is to be attributed rather to the interference of man, than to depredations of certain natirc quadrupeds - a fearfully reduced list, alas!-on whose devoted heads the full wrath of the keeper has for years been indiscriminately poured.

How is it that in newly discorered countries and in thinly inhabited regions, various kinds of gallinaceous birds are found to flourish in a wild state, to 'increase and multiply' though exposed to the unrestrained attacks of various predatory animals, furred and feathered, whom Natureever just-has placed as salutary checks on the excessive augmentation of their numbers, while, conversely, the increase of population and the diminution of all kinds of game are simultanenus? Look at the wild turkey in America. See how he has receded before the destroying breath of civilization. The same has once occurred with the capercaillie in Scotland, and the laxity of the game laws in Sweden has already banished him from many of the Scandinarian provinces. The bustard is an example at our own doors. The pintado, or Guinea fowl, in certain nuaritime 
parts of $\Lambda$ frica, and the red grouse in the central and southern counties of England.*

Let us now consider calmly the case of some of our proscribed quadrupeds, a certain portion of whom, it must be allowed, are simners against the game laws; while others again offend but in a limited degree, or are wholly innocent of the crimes laid to their charge. To begin with the former.

The fox, from his hereditary cunning-a matter of notoriety in the earliest ages of the worldhis habit of prowling by night, and above all, the insatiable and merciless character of his appetite, which prompts him at the moment of success to sacrifice every victim within his reach, is perhaps the most formidable four-footed enemy to game birds; but as, in the estimation of every admirer of the noble and truly national sport of fox-hunting, reynard himself is pre-eminently entitled to protection, and therefore ought to stand at the very head of the game list, he is in no want of strenuous advocates or admirers in the

* It is an asecrtained fact, that in Ireland grouse, partridges, and hares have greatly increased within the last two years; and looking at the question statistically, there seems no reason to doubt that this eireumstanee is due to the reduction of the population, partly by the late famine and partly by extensive emigration. 
British islands. However, in those districts where his favourite prey, the rabbit, has been greatly reduced or exterminated, security to the pheasant and partridge, and immunity to the fox, are quite incompatible. In such cases the keen foxhunter and the zealous game preserver can seldom be called 'birds of a feather,' and unless they recur to the alternative of keeping up a moderate supply of rabbits-which the fox will always take in preference to any other food-perhaps the best thing they can do is to pitch their tents respectively in such districts as, from natural or local circumstances, may afford to each the unrestrained indulgence of his farourite sport.

The real wild cat (felis catus) is probably no longer a denizen of the southern or central parts of England, is very rare in the northern counties, and of less frequent occurrence in Wales and even in Scotland than formerly. In short, notwithstanding the inaccessible nature of his retreats among the rocky glens in the Highlands, he is in a fair way of following in the footsteps of the bear and the wolf, and the facilities afforded for his destruction by the modern fowling-piece will doubtless accelerate his fate-one that will meet with little commiseration except from the naturalist.

Not only have game birds, poultry, and young 
lambs fallen victims to the wild eat, but even man himself has occasionally been vanquished in a personal encounter with ' the British tiger.' There is an instance on record of a shepherd having been mortally wounded in Scotland, and several of severe injurics having been received from imprudently coming into close quarters with this formidable quadruped. Although comparatively rare in Ireland, the species still exists among some of the mountains of Connaught. Mr. Maxwell, in his usual felicitous manner, relates an anecdote characteristic of its truculent propensities, the scene of which was in that remote district.*

House cats are frequently known to run wild; and although there is an obvious tendency in these animals, when they have taken to the woods, to assume the grey, or tabby, colour after the second or third generation, yet they must not be confounded under any circumstances with the real wild cat. The two species are manifestly distinct. Besides the superior size of the latter; the comparative smallness of the head and the far greater development and different form of the tail are well marked characters, which are sufficient to upset the once favourite theory that felis

* 'Wild Spurts of the West,' vol, ii. p. 107. 
catus was the original founder of our domestic race.*

Gamekeepers need not be told that a more incorrigible poacher does not exist than a common cat which has been bred in the woods, or which, although originally an efficient mouser and a useful occupant of the barn, has gradually acquired the habits of a vagrant. The strength and size which a male cat will sometimes attain under such circumstances is extraordinary-although he never arrives at the proportions of his irreclaimable congener.

In the parish of Bignor in West Sussex, there lives a cottager whose thrifty housewife possesses a raluable ally in the person of a gigantic tom-cat. The most efficient of foragers is he, and 'many a time and oft' have his poaching expeditions protracted the too lavish expenditure of the treasures of the pork-tub. His ordinary victims are halfgrown rabbits, which he captures in the dusk of the evening, and which he invariably conveys in retriever fashion to the residence of his owner. It is only marvellous how he has hitherto escaped the snares and traps of a neighbouring keeperone of the wiliest of his calling. Howerer, his foraging expeditions have as yet, I belicve,

* For some interesting particulars on this subject, see 'Bell's British Quadrupeds.' 
been chiefly confined to a furzy common in the immediate vicinity of his master's cottage, where young rabbits,

$$
\text { "—_ and suels small decr, }
$$

Have been 'Tom's food for seven long year."

But woe betide lim if an ornithological fit should tempt him to extend his researches into the adjoining preserves. His fate will then be sealed, for his sagacity and self-denial must indeed be greater than fall to the lot of other cats, to enable him to resist the varied temptations of fish, flesh, and valerian, with which his archenemy has decked the path to destruction.

Of the weasel family (mustelide) the marten (martes foina), commonly, but erroneously, called the marten cat, has been almost exterminated in England. Although in former days its depredations among game were of no trifling character, yet it is surely to be regretted that the species should since have been persecuted down to the very verge of extinction. There are many circumstances that would appear to favour the toleration, if not the preservation, of a limited number in the woods of England. The odour that proceeds from a glandular secretion of this animal, and of the pine marten-probably a variety of the same species-so far from being fetid or offensire, is singularly agreeable. Mr. Bell says, "The 
aspect and attitudes of the marten are perhaps more elegant than those of any other of our native quadrupeds. Endowed with great liveliness and activity, its movements are at once rapid and gracile. Its limbs are elastic, its body lithe and flexible, and it bounds over the ground with equal speed and grace. *** If taken young it is susceptible of great docility; and the remarkable elegance of its form, the beauty of its fur, and the playfulness of its mamners, render it one of the most pleasing of pets."

The polecat (mustela putorius). The stoat (mustela erminea), and the common weasel (mustela vulgaris), are neither so prepossessing in appearance nor so attractive in manners; while our olfactory nerves-especially in the case of the first-prompt us to pronounce at once a hasty verdict against them. The last two are very generally distributed, and, although hostile to game birds, yet perform good service to the agriculturist in the destruction of four-footed rermin. The weasel is eminently useful in the granary and the straw-yard; far more efficient than a cat, and a worthy ally of the white owl. Indeed besides the quantity of rats which it destroys, cren during a temporary sojourn in such situations, a still greater number of those noxious animals are frequently induced to migrate from the spot 
where it has once permanently established its quarters.

A large barn in my neighbourhood had for years been infested by rats, and a regular auto da fe used to take place there about Michaelmas every year. Having heard of the extraordinary 'sport' furnished on such occasions, I particularly solicited an invitation to one of these 'battues.' The eventful day at last arrived. The great gates were closed. Every hole was carefully stopped. A pack of expectant terriers, with cocked ears and determined visages, looked on patiently as sheaf after sheaf was pitched from one side of the building to the other, without a single rat being exposed to view. At last the floor was visible. Not even a mouse had been seen. The last truss was lifted, and there a solitary little weasel was discovered, who-sad to relate-fell a victim to the disappointed dogs before his rescue could be effected.

In a former chapter I have endeavoured to espouse the cause of the poor badger, and to deprecate his persecution at the hands of the gamepreserver. With far greater justice, I regret to say, the hedgehog (erinaceus Europaus) has earned for himself a bad character during the breeding season. No one was ever more reluctant than myself, for many a day, to credit the evil reports 
that continually reached me, touching his robbery of pheasants' nests-and even now I am satisfied that his destruction of worms, insects, mice and snakes, fully atones-in a general sense-for his poaching offences; but as an egg-devourer he stands pre-eminent among British quadrupeds. To a superficial observer his structure would appear to be rather of a defensive than an offensive character, but 'facts are stubborn things.' I speak from personal experience when I say that if a steel trap be set over night in any wood where hedgehogs are known to exist, and baited with an egg, the capture of one of those animals will, in nine cases out of ten, be the result.

The weasel frequently pursues moles into their subterranean habitations, and is then occasionally caught in the springes which are in ordinary use for their destruction. I have receired two specimens from my own neighbourhood within the last few years which had been killed in this way. Here, I am inclined to think that these particular weasels perhaps met with their deserts, for they were engaged in the pursuit of an animal scarcely less useful than themselves, in many points of view, to the farmer. This may appear a bold statement to those cultivators of the soil who hare all their lives been engaged in the persecution of the mole; who only regard the partial injuries 
committed by him, and obstinately refuse to look at the other side of the picture. Much conflicting testimony might certainly be adduced. My own observations, I confess, lead me to beliere that in this case the good far preponderates over the evil, while in order to arrive at the truth it may be necessary, as Mr. Bell observes, "to divest our minds as well of the prepossessions of the naturalist, as of the prejudices of the agriculturist." Let us first hear what an enlightened individual of the latter class says on this subject. I quote from a letter of the Rev. G. Wilkins-to whom I have already referred at page 5 -which appeared in the 'Essex Herald,' in May 1848, and was addressed "to a farmer who had written to him inquiring how the wire worm had been exterminated in his land," "and contains," observes the editor, "much sound, though we dare say unpalatable, doctrine to the orners of smooth lawns and trim bedded gardens."

"Some ten years since, when I came to my living, and commeneed cultivating the little land I hold, it was, I may say, full of wire worms. Nothing could have been worse, for my crops were in some places ruined by them entirely. What then did I do? I adopted a plan which I recommended and published in periodicals many years since, viz., encouraging moles and partridges 
on my lands. Instead of permitting a mole to be caught, I bought all I could and turned them down alive; and soon my fields, one after another, were full of mole hills, to the amusement of all my neighbours, who at first set me down for half a lunatic; but now several adopt my plan, and are strenuous adrocates of it. My fields became exactly like a honeycomb; and this continued even among my standing, and growing, and ripening crops; not a mole was molested, but I still bought more. This summer I had fourteen brought, which I turned down, but they were not wanted; I have nothing for them to eat: all that moles live upon is destroyed, and so, poor things, they must starve or emigrate to some distant land, and thus get borstringed by savage men whom they aim to serve. Adopt my plan and it will be sure to answer."

This, then, is the advice of a practical agriculturist. Let us now hear Mr. Jesse, who with that benevolent feeling that characterizes all his writings, thus advocates the cause of this proscribed little animal.

"That moles were intended to be beneficial to man, there can I think be no doubt. I have been assured that where old mole-hills are most abundant on sheep pastures, the latter animal is generrally in a healthy state, as it feeds on the wild 
thyme and other salubrious herbs which grow on these heaps of earth. Where these have been levelled and cleared away, sheep are not found to thrive as well as they did previously. 'This fact was confirmed to me by Mr. Hogg, the Ettrick shepherd, who deprecated the practice of removing mole-hills. In Lcicestershire, where old mole-hills are extremely abundant in the fine and extensive pastures which are to be found in that county, sheep thrive well and are generally healthy. In further confirmation also of what has been stated, I have been assured that in consequence of the mole-hills having been destroyed in a park which formerly belonged to the present Earl of Essex, in Herefordshire, the deer in it never afterwards throve well." *

But although there may still be room for discussion as to the utility or hurtfulness of the mole in its bearing upon the affairs of the agriculturist, the game preserver can hardly contrive to pick a quarrel with it on his own account; and the poor squirrel miglt be supposed to deserve at least equal immunity. But alas! such is not the case. More than one instance of some halfstarved incarcerated individual having partaken of raw meat has been cruclly adduced as a proof of its blood-thirsty propensities; nay, it was once my

* Gleanings in Natural History, 1st scries, rol. i. p. 280. 
misfortune to meet with a keeper who coolly assured me that he had lately shot a squirrel in the act of devouring a half-grown pheasant, which it had carried, in spite of its struggles, to the summit of a tall tree with as much ease as if it had been a filbert. This man was in the employment of an uncompromising preserver of game, at whose hands all other ' fowls of the air and creeping things' found but little mercy, and squirrels and stoats were included in the same black list. A subsequent cross-examination, however, convinced me that his story was a pure invention of the brain, got up at the moment as a conclusive argument to repel my attempted vindication of his little victims, several of which were lying about the gravel-walks in various stages of decomposition - for the ferret-hutch had been already glutted, and there was no room on the gable end of the barn for another culprit. My expostulations, I grieve to say, were equally fruitless with master and man. In that extensive and thickly wooded district the species may survive for many years in spite of all this persecution. The real offence is, the nibbling off the upper shoots of the Scotch fir during scasons of scarcity : a plausible casus belli is thus established against it, and every other crime, possible and impossible, is laid to its charge: 'the wish is father to the thought:' the 
kecper is a ready witness against the accused; and under such circumstances-the master being at once prosecutor and judge, and the servant both witness and executioner-the poor squirrel obtains but slender justice. That some of the Rodentia will occasionally indulge in animal food, there can be no doubt; the rat is a familiar example-he indeed is an insatiable devourer of eggs, and a pitiless cnemy to young partridges during a sickly season-but I firmly believe that the squirrel rarely or never exhibits carnivorous propensities. As to the conduct of animals when kept in confinement, their nature becomes so completely altered by durance vile, and the ignorance or neglect of their captors, that it can never be considered a fair index to their habits in a state of nature. If half a dozen field mice were put into a cage and left without food for a couple of days, the weakest would be deroured by the others; and if the cruel experiment were prolonged, the same result would follow, until none survired but the strongest indiridual of the party. Under nearly similar circumstances, cren cirilized man himself has become a cannibal! That the squirrel may-during long, dry summers, when the verdure of the woods, and on the surface of the earth has been parched by the burning sun; when the dead leares of the previous year have 
been all explored over and over again for acorns and beechmast, and not another nut remainshave been detected occasionally in the act of derouring the eggs, or even the unfledged young of a small bird, is just possible; although after much patient observation and diligent inquiry, I am bound to say that I have seen nothing of the sort, nor met with a single well-authenticated instance of the kind. The list of our indigenous quadrupeds is already too restricted to admit of his extermination; and I, for one, earnestly hope that the day may be far distant when the eye of the British naturalist is no longer to be gladdened by the contemplation of his beautiful form and his sprightly bounds. Then indeed will our woods and groves be deprived of one of their greatest ornaments.

FINIS.

LONION :

Printed by Santel Bentzer \& Co.

Bangor House, Shoe Lane. 
Lately pullished, uniform with thes Volume,

A NEW EDITION OF

\title{
ORNI'THOLOGICAL RAIBLES IN SUSSEX:
}

W1T11 I

\section{CATALOGUE OF THE BIRDS OF THAT COUNTY,}

\author{
AND REMARKS ON THEIR IOCAL DISTRIBUTION.
}

By A. E. KNOX, M.A., F.L.S., \&c.

"A. E. Knox, Esq.. is well located on our southern coast for observations on the migratory birds, and bestows time and great attention to the subject."-Yarrell's History of British Birds, vol. i. page 404, second edilion.

\section{OPINIONS OF THE PRESS.}

"There are still ton many sportsmen who need to have their slumbering senses aroused, and to be taught the interest they might find in a converse with Nature. Such a one is not Mr. Knox. He is manifestly a sportsman, and a keen one. . . . A Already our readers perceive that we are introducing to them a genuine enthusiast. In truth, tliough written by a man whose profession and habits differ in many respects from his, the volume continually reminds us of our old delight, White of Selborne. Like White, Mr. Knox is a scholar bred at Oxford, and like White he is a close observer of Nature, who jots down what he sees in his own neighbourhood or excursions from nuere love to that of which he writes, and not to make a book." - Quurterly Rerieu.

"The pleasant pages before us are evidently the work of one who has studied Nature in her most attractive form. A sportsman, a naturalist, and a gentlenan, he enters on his subject with a!l the ardour which a love of his farourite pursuits inspires, and with a freshness of feeling seldom found but among those who, like himself, hare followed over hill and dale those manly sports in which our countrymen generally excel."-Morning I'ost.

"We must say that Mr. Knox is one of the most agreeable guides it has been our good luek to accompany in these excursive rambles. Patient observation, good feeling, gentlemanly manner, scientifie eultivation, and a very taking style, recommend his volume to every reader of taste and discernment." - Lilerary Gazette.

"This is a delightful book, written by a man of talent and a genuine lover of Nature."-Brighlon Herald.

"The author is a man after one's own heart, regardless of a little fatigue or incouvenience when in the pursuit of natural-history lore.... The subject of migration is treated with much skill, and ornithologists are deeply indebted to Mr. Knox for his capital and novel obserwations on this subject." Zoologist. 


\section{Opinions of the Press (continued).}

"Every book club should order this delightful rolume."-Critic.

"We are always inclined to listen to a man who gives us the fruit of his own observation and experience. We like to have our flowers with the dew upon them. .... Mr. Knox's book is a storehouse of these self-gathered facts."-Brighton Guardian.

"A most interesting and instructive book." - Sussex Adrertiser.

"We have now to notice Mr. Knox's "Ornithological Rambles in Sussex,' and give this work most unqualified praise."-Morning Herald.

"Our woods and coast offer to the ornithologist treasures which many will, for the first time, learn from the pages of Mr. Knox, whose 'Ornithological Rambles in Sussex' are a rich repertory of information on this most attractive subject. . . . The book is adorned with some clever illustrations from sketches by Mr. Knox himself." - Brighton Gazette.

"A delightfully readable little volume. .... We find ourselves, howerer unaddicted to MIr. Knox's favourite pursuit, imperceptibly interested in the fate of a wagtail or the fortunes of a crow."-Sussex Agricultural Ex. press.

"Mr. Knox, we need scarcely say, is an ardent lover of the country, and for that reason he paints rural scenery with exquisite truth, and points out some of the finest rambles to be met with in all merry England." - Britannia.

"Written with spirit and care."-Hampshire Telegraph.

"This little book has all the merit of genuine out-of-door observation ; and the sportsman as well as the ornithologist may derive entertainment from its pages. All records of instinct made from personal inspection must have interest; and to a love of that sort of research our author adds a taleut for humorous narration."-Globe.

"The work before us contains the observations of an acute and intelligent mind. . . . Mr. Knox is evidently a disciple of the school of White, possessing mucli of the same kind of knowledge and the same benevolence of disposition."-English Revicu.

"A delightful book. . . . . The author is as good a sportsman as an ornithologist."-English Churchman.

"The author has brought to his work the two great elements of successacute observation and an enthusiastic love of his subject." - Church of England Quarterly Rericu.

"It is a genial, good-tempered book. Mr. Knox is equally spirited with pen and pencil."-Christian Remembrancer.

"In the writings of Mr. Waterton we have essays on natural history worthy to be placed by the side of those of White:-and in the letters of Mr. Kuox before us, we observe the same spirit and the same love of Nature. ... Although this book contians a list of hirds found in the county of Sussex, the most delightful parts of the volume are the author's personal advontures and olservations in pursuit of his favourite objects."-Athenaum. 


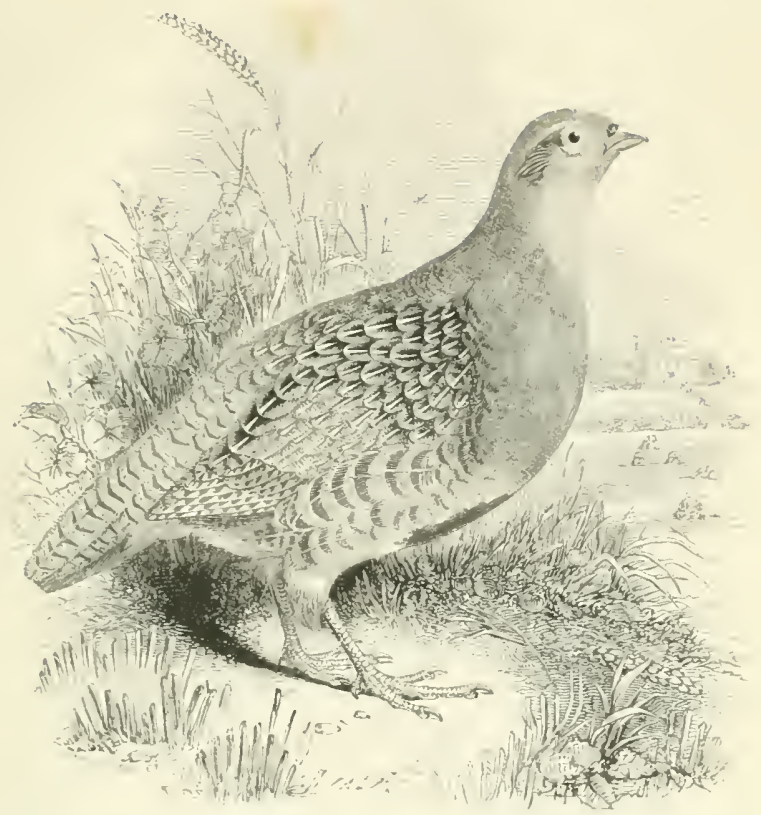

\section{A HISTORY OF BRITISH BIRDS.}

BY WILLIAM YARRELL, F.L,S., V.P.Z.S., IC.

This Work contains a I istory and an Engraving of each species of Birl found in Britain. The three volumes contain 535 Illustrations. Second Edition. 3 vols. demy 8vo. 4\% 14s. Gd. A Supplement to the First Edition, demy 8vo. 2s. 6l., royal 3vo. 5s.; imperial 8vo. 7s. fod.

JOHN VAN VOORST, I, PATERNOSTER RUIF. 



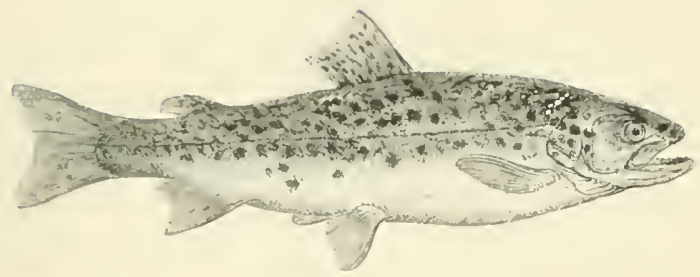

\section{A HISTORY OF BRITISH FISHES.}

BY WILLIAM YARRELL, F.L.S., V.P.Z.S., Sic.

Second Edition, containing a History and an Engraving of every British Fish, and many accessary Illustrations; in all nearly Five Hundred. Two Vols. 8vo., price 3\% A Supplement to the First Fdition, 8vo. 7s. 6u.; royal 8vo. 15s. : imperial 8ro. 22s. 6.l.

JOIIN VAN VOOLST, 1, PATERNOSTER ROTI. 



\section{A CATALOGUF OF THE BOOKS}

\section{PUBLISHED Br Mr. VAN VOORS'T.}

BY arthur aitin, F.L.S., F.F.S., Sic. late Sec. to the Institution.

ILLUSTRATIONS OF ARTS AND MANUFACTURES; being a Series of Papers on Pottery, Limestone and Calcareous Cements, Gypsum and its uses, Furs and the Fur Trade, Felting and Hatmaking, Bone and its uses, Tortoiseshell and Whalehone, Antiquarian and Metallurgical History of Iron, Engraving and Etching, and on Paper. Read before the Society for the Encouragement of Arts, Manufactures, \&c. In foolscap 8vo., Illustrated. 8s, cloth.

BY D. T. Anstri, M.A., F.R.S., Professar of Gealogy in King's College, London, \&c.

THE ANCIENT WORLD; or, Picturesque Sketches of Creation.

With 149 Illustrations. A New Edition, Post 8vo., 10s. 6r.

THE GEOLOGIST'S TEXT BOOK. Foolscap 8vo. 3s. 6d.

THE GOLD SEEKER'S MANUAL. Foolscap 8vo. 3s. 6 $l$.

By Cbarles (4. babington, M.A., F.L.S., F.Z.S., \&.c.

A MANUAL OF BRITISH BOTANY; containing the Flowering Plants and Ferns, arranged according to the Natural Orders. Second Edition, $12 \mathrm{mo}, 10 \mathrm{~s}$.

\section{By Cfomas bieale.}

THE NATURAL HISTORY OF THE SPERM WHALE, and a Sketch of a South Sea Whaling Voyage. Post 8vo. 12s.

Br jrofessor BeIl, Sec. R.S., F.L.S., F.G.S.

A HISTORY OF BRITISH REPTILES. Second Edition, with 50 Wood Engravings. 8vo. 12s.

A HISTORY OF BRITISH QUADRUPEDS, including the Cetacea. Nearly 200 Illustrations, 8vo. 28s. A few copies also in royal 8vo. 2l. $16 \mathrm{~s}$, imperial 8 vo. $4 l .4 \mathrm{~s}$.

A IISTORY OF BIITISH CRTSTACEA. Now in Course of Publication, in Parts at 2s.6d., or large paper 5s.

Br CEDmarò ظoban, M.D.

THE HONEY BEE ; its Natural History, Physiology, and Man. agement. A New Edition, $12 \mathrm{mo}$, with many Illustrations, 10s. $6 d$.

BY Gottlicb Lorrius.

A TREATISE ON TIIE MANAGEMENT OF FRESH-WATER FISH, with a view to making them a Source of Profit to Landed Proprietors. 8vo. 5s.

A TREATISE ON THE PRODUCTION AND MANAGEMENT OF FISH IN FRESII WATERS, by Artificial Spawning, Brecding, and Rearing: showing also the Cause of the Depletion of all Rivers and Streams. 8vo. 5 s. 
$\mathrm{Bv}$ Cִyarles Ilucirn tonaparte, Prince of Canino.

A GEOGRAPHICAL AND COMPARATIVE LIST OF THE BIRDS OF EUROPE AND NORTH AMERICA. 8ro. $5 s$.

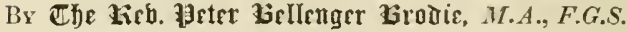

A HISTORY OF THE FOSSIL INSECTS IN THE SECONDARY ROCKS OF ENGLAND. Accompanied by a Particular Account of the Strata in which they occur, and of the circumstances connected with their preservation. With 11 Plates. 8vo. 9s.

By Ioseph Lullar, M.D., and Zencurn Bullar, of Lincoln's Inn.

A WINTER IN THE AZORES, and a Summer at the Baths of the Furnas. Two rols. 8 ro., with Illustrations, 28s.

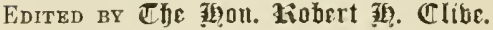

DOCUMENTS CONNECTED WITH THE HISTORY OF LUDLOW AND THE LORDS MARCHERS. Imperial 8vo. $31 \mathrm{~s}, 6 d$.

By Jouathan Conch. F.L.S., Member of the Royal Geological Society and of the Royal Institution of Cornuall, \& $\&$.

ILLUSTRATIONS OF INSTINCT, deduced from the Habits of British Animals. Post 8 vo. $8 s .6 d$.

Bv The Kish. IJ. G. Cumming, M.A., F.G.S., Fice-Principal of King William's College, Castletorn.

THE ISLE OF MAN; its History, Physical, Ecclesiastical, Civil, and Legendary. Post 8vo., Illustrated with Views and Sections, 12s. $6 d$.

$\mathrm{By}$ 三̈ir \$ołı Grabam Dalvell, Bart.

RARE AND REMARKABLE ANIMALS OF SCOTLAND, Represented from Living Subjects : with Practical Observations on their Nature. 2 vols. 4to. containing 109 Coloured Plates, 6l. 6s.

By 39enry Boublrday.

A NOMENCLATURE OF BRITISH BIRDS, for Labelling Collections of British Birds and their Eggs. Third Edition, Is. 6d. sewed.

Br James ZL. Drummonid. M.D., Professor of Anatony and Physiology in the Belfast Royal Institution.

FIRST STEPS TO ANATOMY. With I2 Illustrative Plates. $12 \mathrm{mo} .5 \mathrm{~s}$.

By Robert Dumn.

THE ORNITHOLOGIST'S GUIDE TO TIIE ISLANDS OF ORKNEY AND SHETLAND. Post 8 ro. $5 s$.

B) ७rofessor ED. Aforbes, F.R.S., F.L.S., F.C.S.

A HISTORY OF BRITISH STARFISHES, and other Animals of the Class Echinodermata. 8vo., witl more than 120 Illustrations, $15 s$, or Royal 8vo. 30s.

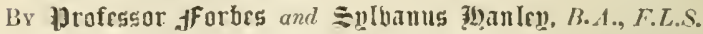

A HISTORY OF BIRITISH MOLLUSCA AND THEIR SIIELIS. Vol. I. 8vo., 1l. 11s.6d, Vol. II. 1l. I5s.; or Royal 8vo. with the Plates coloured, Vol. 1. 3l. 3s.; Vol. II. 3l. 10s.

JOHN VAN VOORST, I, PATERNOSTER ROW' 
I3r professor dforbes and Capt. $\tau$. Epratt, $I . N$.

TRAVELS IN LYCIA, MILYAS, AND THE CIJYRATIS, in Company with the late Rrv. E. T. Mavik1. With numerous Illustrations, including Views of the Scenery, I'lans of Ancient Citics and Buildings, Plates of Coins and Inscriptions, Cuts of liock Tombs, Fossils, and Gcological Sections; and an original Mlap of Lycia. 22 vols. 8ro. 36 s.

By liobert Carner, F.L.S.

TIE NATURAL HISTORY OF STAFFORDSIIRE, comprising its (ieology, Zoology, Botany, and Meteorology; also its Antiquitics, Topography, Manufactures, \&c. Illustrated, 8ro. Il. Is.

B. 1]. 31). (Jossr.

THE BIRDS OF JAMAICA. Post 8ro., price 10 s.

ILLUSTRATIONS to this Work, of Specics not heretofore figured. Imperial 8vo., 64 coloured plates, $36 s$.

TIIE CANADIAN NATURAIIST. With 44 Illustrations of the most remarkable $\Lambda$ nimal and V cgetable productions. Post 8vo. 12s.

$\mathrm{Br}$ Charles 3iscrbert, of the Middle Temple, Barrister-at-Law.

GROTIUS INTTRODUCTION TO DUTCH JURISPRUDENCE. Now first rendered into English. Royal Evo. $12.11 \mathrm{~s} .6 \mathrm{~d}$.

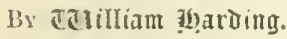

INIVERSAL STENOGRAPIIY; or, A New and Practica] System of Short IJand Writing, on the basis of Taylor. 12mo. 3s. sewed. $3 s .6 \mathrm{l}$. bound.

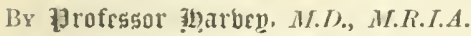

THE SEA-SIDE BOOK: being an Introduction to the Natural History of the British Coasts. Second Edition. Fcap. 8ro., with 69 1llustrations, $5 s$.

A MANUAL OF THE BRITISII MARINE ALGE: containing Generic and Specific Descriptions of all the known British species of Sea-Weeds, with Plates to illustrate all the Genera. 8vo. 21s., coloured copies, 3 Is. $6 d$.

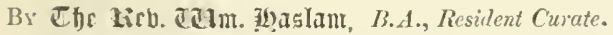

PERRAX- \%ABLLOE; with an Account of the Past and Present State of the Oratory of St. l'jan-in-the-Sands, and Remarks on its Antiquity. Foolscap 8vo, with several Illustrations, 4s. 6d.

By Arthur 3tenfrey, F.L.S., Lecturer on Botany at St. George's Hosyital.

THE RUDIMENTS OF BOTANY. A familiar Introduction to the Study of Plants. 16 mo, with illustrative Wood-cuts, 3s. 6r.

OUTLIXES OF STRICTURAL AND TIIYSIOLOGICAL IBOTAXY. With I8 Plattes, Foolscap 8ro. 10s. 6d.

Br ftr. 3benfren and alfrè Eulk, M.L.C.S., M.E.S.

ANATUMICAL MANIPULATION; or, Mcthods of pursuing Practical Investigations in Comparative Anatomy and Physiology: also an Introduction to the L'se of the Microscope, Sc., and an Appendix. Foolscap 8 ro., with Diagrams, 9s.

JOHN VAN VOORST, 1, PATLRNOSTER ROIF. 


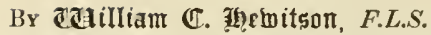

COLOURED ILLUSTRATIONS OF THE EGGS OF BRITISH BIRDS: accompanied with Descriptions of the Eggs, Nests, \&c. Two rols. 8 ro. $4 l$. 10s. The arrangement adopted in this work is that employed by Mr. Yarrell in his "History of British Birds."

By Capt. 포. 3L. Linsqamen Ebbetson, K.R.E., F.G.S.

NOTES ON THE GEOLOGY AND CHEMICAL COMPOSITION OF THE VARIOUS STRATA IN THE ISLE OF WIGHT. With a Map in Relief, colonred Geologically, 8vo. 7s.6d.

By Che Reb. Zleonard 3cunus, M.A., F.L.S.

OBSERVATIONS IN NATURAL HISTORY; with a Calendar of Periodic Phenomena. Post 8vo, 10s. 6d.

By EDmard Ifsse, F.L.S., Author of "Gleanings in Natural History." AN ANGLER'S RAMBLES. Contents: Thames Fishing, Trolling in Staffordshire, Perch Fishing-club, Two Days' Fly-fishing on the Test, Luckford Fishing-club, Grayling Fishing, a Visit to Oxford, the Country Clergyman. Post 8vo. 10s.6d.

By Dr. Feorge Jofntotor, LL.D.

A HISTORY OF THE BRITISH ZOOPHYTES. Second Edition, in 2 vols. 8 vo., with an Illustration of every Species. 2l. $2 s$.; or on large paper (royal $8 \mathrm{vo}$. ) $4 l .4 s$.

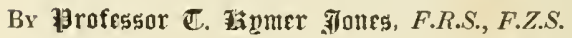

THE NATURAL HISTORY OF ANIMALS. Vol. I., with 105 Illustrations, post 8ro. $12 s$.

A GENERAL OUTLINE OF THE ANIMAL KINGDOM AND MANUAL OF COMPARATIVE ANATOMY. In one thick vol. 8vo., containing nearly 350 Illustrations, 38s. Royal 8ro. 3l. $16 s$. Imperial 8vo. 5l. 14 s.

BY E. ff. Jiclaart, M.D., F.L.S., Army Medicul Staff.

FLORA CALPENSIS: Contributions to the Botany and Topography of Gibraltar and its neighbourhood, with Plan and Views of the Rock. To which is added a Translation of En. BoIssier's Account of the Vegetation of Gibraltar, with Description of New Species. In 1 vol. 8vo. cloth, $10 s .6 d$.

By A. CE. Jinox, M.A., F.L.S.

ORNITHOLOGICAL RAMBLES IN SUSSEI; with in Systematic Catalogue of the Birds of that County, and Remarks on their Local Distribution. Post 8ro,, with 4 Lithographic Views, 7 s. $6 d$. Second Edition.

$\mathrm{Br}$ George 3Lurfori, A.L.S., F.R.S.E.

A FIORA OF THE NEIGHBOURHOOD OF REIGATE, SURRFY, containing the Flowering Plants and Ferns. I2mo. with a Map of tlic District, $5 s$.

JOIN VAN VOORST, I, PATERNOSTER HOW. 
By Ebe lieb. ప. C. ftlalam, M..A., M.A.S.

A SYSTEMATIC CATALOGUE OF TIIE RG(iS OF RRITISII IBIRDS, armanged with a View to supersede the use of Labels for liggs. On writing-paper. 8vo. 8s. 6d.

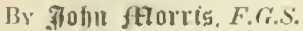

A CATALOGUE OF BRITISH FOSSILS. Comprising all the Genera and Species hitherto described; with References to their Geological Distribution, and to the localities in which they have been found. $8 \mathrm{ro}, 10$ s.

BY Ejomas ftloule.

HERALDRY OF FISII. The Engravings, 205 in number, are from Stained Glass, Tombs, Sculpture and Carring, Medals and Coins, Rolls of Arms, and Pedigrees. 8vo., 2]s. A few on large paper (royal $8 \mathrm{vo}$ ) for colouring, price $2 l \cdot 2 s$.

By EDmard Xremman, F.L.S.

A HISTORY OF BRITISII FERNS AND ALLIED PIANTS. With an Engraving of Each Species. Second Edition, 8vo. 25s.

A FAIILIAR INTRODUCTION TO THE HISTORY OF INSECTS. With numerous Illustrations. One vol. 8vo. 12s.

By Jurofessar Oben, F.R.S., \&.c.

A HISTORY OF BRITISH FOSSIL MAMMALS AND BIRDS. In 8vo., with 237 Illustrations, price $11.11 s .6 d$; ; on large paper (royal $8 \mathrm{vo}$.), $3 \% .3 s$.

ON PARTHENOGENESIS; or, The Successire Production of Procreating Indiriduals from a single Orum. 8 ro. $5 s$.

ON THE NATURE OF LIMBS. A Discourse delivered on Friday, February 9th, at an Erening Meeting of the Royal Institution of Great Britain. 8vo. $6 s$.

ON THE ARCHETYPE AND HOMOLOGIES OF THE VERTEBRATE SKELETON. Twenty-eight Woodcuts, Two Folio Plates, and Three Tables of Synonymes. 8 vo. 10s.

DESCRIPTION OF THE SKELETON OF AN EXTINCT GIGANTIC SLOTH. With Observations on the Osteology, natural Aftinities, and probable Habits of the NIegatherioid Quadrupeds in general. 4 to. $11.12 s .6 \mathrm{~d}$.

DESCRIPTIVE AND ILLUSTRATIVE CATALOGUE OF TIE PHYSIOLOGICAL SERIES OF COMPARATIVE ANATOMY, contained in the Museum of the Royal College of Surgeons in London. 5 rols. 4 to., each $1 l .11 s, 6 d$.

CALCULI AND OTHER ANIMAL CONCRETIONS, $10 s$. plain, 1l. $11 s .6 d$. coloured.

FOSSIL ORGANIC REMAINS OF MAMMALIA ANU BHRDS. $21 s$.

Bv Af. a. Đalky, M.A.

A manual of gutilic moldings. A Practical Treatise on their Formation, Gradual 1)evelopment, Combinations, and Varieties; with full Directions for copying them, and for determining their Dates. Second Ed., Illustruted by nearly 600 Examples. 8ro. $7 s .6 d$.

JOHN VAN IOORST, I, PATERNOSTER ROW. 
BY ftr. Baley (continued).

THE CHURCH RESTORERS; A Tale, Treating of Ancient and Modern Architecture and Church Decorations. Foolscap 8vo. 4s. 6d.

A MANUAL OF GOTHIC ARCHITECTURE. With a full Account of Monumental Brasses and Ecclesiastical Costume. Foolscap 8vo. with 70 Illustrations, 6s. $6 d$.

By The lifb. A. (G. Murchas, Precentor of St. Jolin's College, Bishop's Auckland, New Zealand

FIRST LESSONS FOR SINGING CLASSES. Post 8ro. 2s.6d.

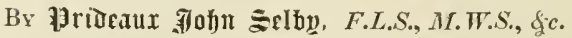

A HISTORY OF BRITISH FOREST-TREES, Indigenous and Introduced. Nearly 200 Engravings. $8 \mathrm{ro.} 28 \mathrm{~s}$, royal 8 ro. $2 l$. $16 \mathrm{~s}$.

$\mathrm{Bv}$ Eomun〉 Ebarpe, M.A., Architect.

A TREATISE ON THE RISE AND PROGRFSS OF DECORATED WINDOW TRACERY IN ENGLAND. Illustrated with 97 Woodcuts and 6 Engravings on Steel. 8ro. 10s.6d.-And

A SERIES OF ILLUSTRATIONS OF THE WINDOW TRACERY OF THE DECORATED STYLE OF ECCLESIASTICAL ARCHITECTURE. 60 Steel Engravings, with Descriptions. $8 \mathrm{ro.} 21 s$.

ARCHITECTURAL PARALLELS; or, The Progress of Ecclesiastical Architecture in England, through the Twelfth and Thirteenth Centuries, exhibited in a Series of Parallel Examples selected from Abbey Churches. 121 Plates in tinted outline, each 18 in. by 12 in. half morocco. 13l. 13s., or large paper, $16 l .10 s$.

BY 2.. ช. ฮฮard, F.L.S.

ON THE GROWTH OF PLANTS IN CLOSELY-GLAZED CASES. 8vo. $5 \mathrm{~s}$.

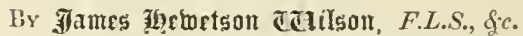

A TRANSLATION OF DE JUSSIEU'S ELEMENTS OF BOTANY. $12 \mathrm{mo}$., with 750 Woodeuts, $12 \mathrm{~s} .6 \mathrm{~d}$.

$\mathrm{Br}$ 3. E. สతilson.

A BRIEF IIISTORY OF CHRIST'S HOSPITAL, from its Foundation by King Edward the Sixth. Serenth Edition, with Six Illustrations, and a List of the Governors. 12mo. $4 \mathrm{~s}$.

By (Tharles colootward, F.R.S.

A FAMILIAR INTRODUCTION TO THE STUDY OF POLARIZED LIGHT; with a l)escription of, and Instructions for ITsing, the Table and Hydro-Oxygen, l'olariscope and Microscope. 8 vo., Illustrated, $3 s$.

BY สฮilliant Yarrell, F.L.S., I.P.Z.S, dgc.

A HISTORY OF BRITISH BIRDS. This work contains a history and a portrait of each species of the Birds found in Britain. The three volumes contain 53.5 Illustrations. Second Edition. $3 \mathrm{rols}$. demy $8 \mathrm{ro.} 4 \mathrm{l}$. $14 \mathrm{~s} .6 \mathrm{~d}$. Royal 8 ro. $9 \mathrm{l}$; or imperial 8ro. 13l. $10 \mathrm{~s}$.

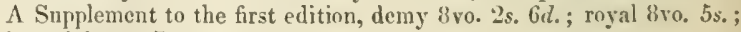
imperial 8ro. 7s. 6rl.

JOHN VAN VOORST, I, PATERNOSTER ROW. 
BY fttr. Darrell (continued).

A HISTORY OF BRITISH FISHES. Second Edition, in two vols. demy 8vo., Illustrated by nearly 500 kingravings, 3l. A Supplement to the First Edition, demy 8vo. 7 s. 6d.; royal 8vo. 15s.; imperial 8vo. 1l. 2s. 6id.

A PAIER ON THE GROWTII OF TIIE SALMON IN FRESH WATER. With Six llinstrations of the Fish of the Natural Size, exhibiting its structure and exact appearance at various stages during the first two years. 1's. sewed,

BAPTISMAL FONTS. A Series of 125 Engravings, Examples of the different Periods, accompanied with Descriptions; and with an Introductory Essay by Mr. P'ALEY. 3ro. 1l. 1 s.

A CATALOGUE OF BRITISH VERTEBRATED ANIMALS, derived from BFL.L's Br. Quadrupeds and Reptiles, and Y ARRELL's Br. Birds and Fishes; so printed as to be applicable for labels. 8 vo. $2 s .6 d$.

A CABINET EDITION OF THE HOLY BIBLE; the Authorized Yersion. With 24 highly-finished steel Engravings. The Historical subjects from the most esteemed paintings of the Old Masters, and the Landscapes from drawings by W. WEstall, A.R.A. In embossed binding, $10 s .6 d$.

A CABINET EDITION OF THE BOOK OF COMMON PRAYER; the Authorized Version. With I0 Engrarings, executed in the best manner, on steel. In cmbossed binding, 4s., uniform with the Cabinet Bible.

DOMESTIC SCENES IN GREENLAND AND ICELAND. $16 \mathrm{mo}$, Illustrated, 2s. 6d.

ELEMENTS OF PRACTICAL KNOWLEDGE; or, the Young Inquirer answered. Explaining, in question and answer, and in familiar language, what most things daily used, seen, or talked of, are ; what they are made of, where found, and to what uses applied. Second Edition, $18 \mathrm{mo}$, with Illustrations, $3 s$.

EveNiNg THOUghts. By a Physician. Post 8ro. 4s, 6d.

THE FIRST PRINCIPLES OF RELIGION, and the Existence of a Deity, cxplained in a Series of Dialogues adapted to the capacity of the Infant mind. $18 \mathrm{mo} .2 \mathrm{~s}$.

INSTRUMIENTA ECCLESIASTICA : a Series of 72 designs for the Furniture, Fittings, and Decorations of Churelses and their Precincts. Edited by the Ecclesiological, late Cambridge Camden, Soeiety. 4 to. 1l. 11 s. 6 d.-A second series is now in course of publication.

LETTERS FROM THE VIRGIN ISLANDS, illustrating Life and Manners in the West Indies. Post 8ro. 9s. $6 d$.

THE LETTERS OF RUSTICUS OF GODALMING. 8vo., with Illustrations, $8 s .6 d$.

LITTLE FABLES FOR LITTLE FOLKS. Selected for their moral tendency, and re-written in familiar words, not one of which excceds two syllables. $18 \mathrm{mo} .1 s .6 d$.

THE POOR ARTIST; or, Seven Eye-Sights and One Object. Fcap. 8 ro. 5 s. 


\section{Ellustrated Reprints.}

AIKIN'S CALENDAR OF NATURE; or, Natural History of each Month of the Year. With additions, by a Fellow of the Linnæan and Zoological Societies, and 18 designs by Cattermole. Small 8vo. 2s. $6 d$. In ordering this volume "Cattermole's Edition " should be particularly expressed.

BLOOMFIELD'S FARMER'S BOY, and other Rural TALES and POEMIS. With 13 Illustrations by SIDNey CoOper, R.A., Horsley, Frederick Tayler, and Thouas IVebster, R.A. Foolscap 8vo. 7s. 6d., large paper, I5s.

DODSLEY'S ECONOMY OF HUMAN LIFE. In 12 Books, with I2 Plates, engraved on steel, from original designs, by Frank HowARD, HARVEY, WILliams, \&c. 18mo., gilt edges, 5 .

GOLDSMITH'S VICAR OF WAKEFIELD. With 32 Illustrations by William Mulreadr, R.A.; engrated by John Thompson. 1l. 1s. square 8ro., or $36 \mathrm{~s}$. in morocco.

GRAY'S ELEGY IN A COUNTRY CHURCH-YARD. Each Stanza illustrated with an Engraving on Wood, from 33 original Drawings expressly made for the volume, by the most eminent Artists. Post 8vo. 9s.-A Polyglot Edition of this volume, with inter-paged Translations in the Greek, Latin, German, Italian, and French languages, $12 s$.

GRAY'S BARD. With Illustrations from Drawings by the Hon. Mrs. JoHN TALвот. Uniform with the Elegy of Gray, to which it forms an appropriate companion volume. $7 \mathrm{~s}$.

SHAKSPEARE'S SETEN AGES OF MAN. Illustrated by W. Mulready, R.A.; J. Constable, R.A.; Sir David IVilkie, R.A.; IV. Collins, R.A.; A. E. Chalon, R.A.; A. Cooper, R.A.; Sir A. W. Callcott, R.A.; Edwin Landseer, R.A.; W. Hilton, R.A. 6s.-A few copies of the First Edition in 4 to. remain for sale.

WATTS' DIVINE AND MORAL SONGS. With 30 Illustrations by C. IV. Cope, R.A.; engraved by John Thompson. Square 8 vo. $7 s$. $6 d$. , or $21 s$, in morocco.

WHITE'S NATURAL HISTORY OF SELBORNE. A New Edition, with Notes by the Rev. Leovarn Jenris, MA., F.L.S., \&e. With 26 Illustrations. Foolscap 8ro. 7s. 6 d.

\section{Shortly will be Published.}

GOODSIR'S (R. A.) ARCTIC VOYAGF.

ANSTED'S (PROFFSSOR) ELEMENTARY COURSE OF GEOLOGY, MINERALOGY, AND PHYSICAL GEOGRAPHY. JOHNSTON'S (DR.) INTRODUCTION TO CONCHOLOGY. LATHAM'S (DR. R.G.) NATURAL, HISTORY OF MAN. KNOX'S (A. E.) GAME BIRDS AND WILD FOWL.

The Illustrations to the Works enumerated in this Catalogue have been designed or drawn and engrated expressly for the Works they respectively eimbellish, and they are never used for other Works.

JOHN VAN VOORST, I, PATERNOSTER ROW. 


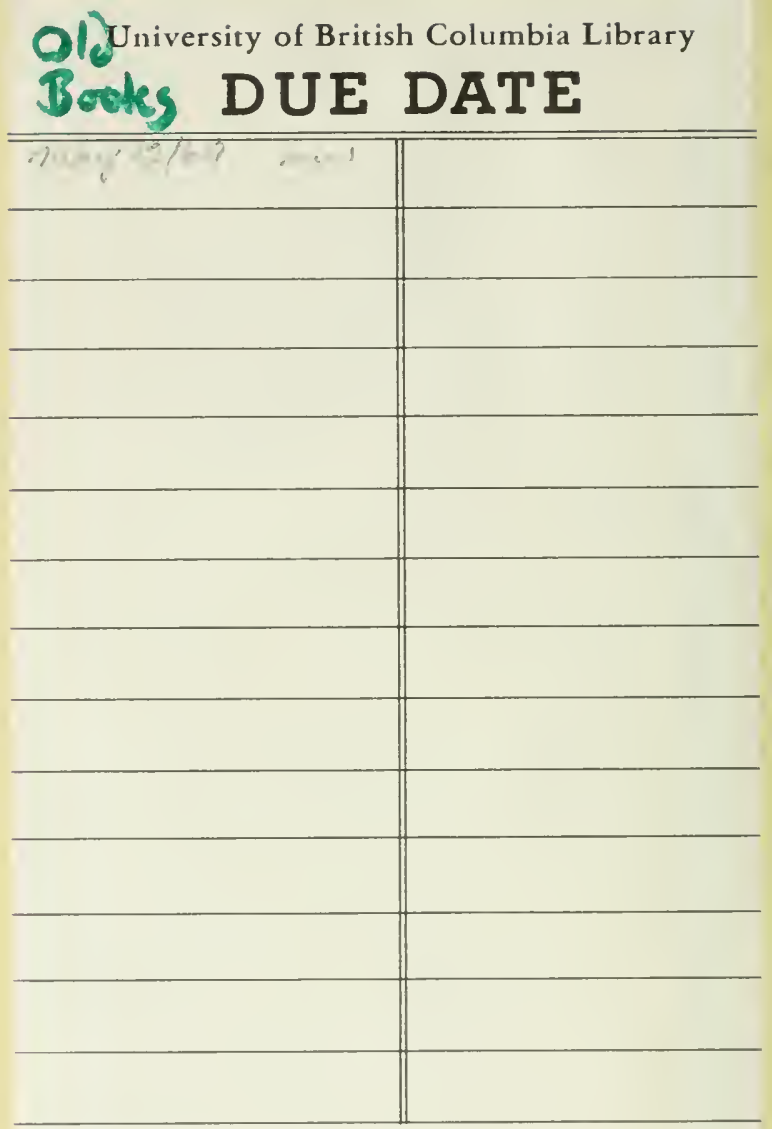

FORM 310 


\section{AGRICULTURE \\ FORESTRY LIBRARY}

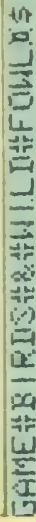

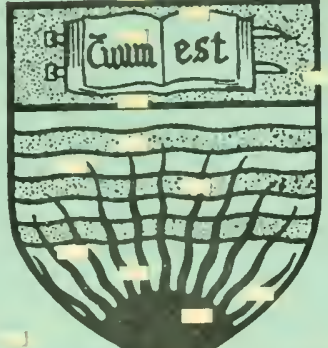


